\title{
WestVirginiaUniversity
}

THE RESEARCH REPOSITORY @ WVU

Graduate Theses, Dissertations, and Problem Reports

2014

\section{A Performance Guide to "First Lines" for Flute and Piano}

\author{
Pamela Murchison
}

Follow this and additional works at: https://researchrepository.wvu.edu/etd

\section{Recommended Citation}

Murchison, Pamela, "A Performance Guide to "First Lines" for Flute and Piano" (2014). Graduate Theses, Dissertations, and Problem Reports. 6281.

https://researchrepository.wvu.edu/etd/6281

This Dissertation is protected by copyright and/or related rights. It has been brought to you by the The Research Repository @ WVU with permission from the rights-holder(s). You are free to use this Dissertation in any way that is permitted by the copyright and related rights legislation that applies to your use. For other uses you must obtain permission from the rights-holder(s) directly, unless additional rights are indicated by a Creative Commons license in the record and/ or on the work itself. This Dissertation has been accepted for inclusion in WVU Graduate Theses, Dissertations, and Problem Reports collection by an authorized administrator of The Research Repository @ WVU.

For more information, please contact researchrepository@mail.wvu.edu. 
A Performance Guide to First Lines for Flute and Piano

\author{
Pamela Murchison
}

Research project submitted to the College of Creative Arts at West Virginia University

in partial fulfillment of the requirements for the degree of

Doctor of Musical Arts in Flute Performance

\author{
Lynn Hileman, DMA, Chair \\ Michael Ibrahim, DMA \\ Mikylah Myers McTeer, DMA \\ David Taddie, Ph. D. \\ Ernest Goeres, Ph. D. \\ School of Music
}

Morgantown, WV

2014

Keywords: flute, piano, Amy Williams, extended techniques Copyright 2014 Pamela Murchison 


\section{ABSTRACT}

A Performance Guide to First Lines for Flute and Piano

by Pamela Murchison

The purpose of this document is to conduct an examination of Amy Williams' First Lines for flute and piano. The composition is a collection of eleven miniatures, each influenced by the first line of a different poem, which require both the flutist and pianist to perform extended techniques. The goal of this project is to create a document that will assist performers in presenting a comprehensive and informed interpretation of First Lines by collecting biographical and pedagogical information selected to help them understand artistic, practical, and theoretical aspects of the work.

The research document will begin with a detailed biography of the composer. The author will conduct and transcribe interviews with Williams, during which information relevant to the composition of First Lines will be discussed. The interviews will explore Williams' compositional influences and techniques, musical training, and the impetus for the composition. This will be followed by short biographical reviews of each of the poets included in First Lines: Toi Derricotte, Patricia Goedicke, Colleen McElroy, Marilyn Chin, and Olga Sedakova. The reviews will include an overview of each poet's general writing style and a discussion specific to all of the poems used will follow. Additionally, Williams' reasons for selecting these particular poems will be explored, as well as the significance of the first lines to both the poems and their corresponding movements. Full texts of the poems used will appear in an appendix, as a reference for future performers of First Lines. The research project will also explore compositional elements used to depict each poem. A chapter dedicated to the extended techniques utilized in the piece for both the flutist and pianist will include definitions for each technique, as well as practice suggestions, gathered from interviews the author will conduct with past performers of First Lines, including Andrea Ceccomori (for whom the piece was written) and Alberto Almarza, Artist Lecturer in Flute at Carnegie Mellon University in Pittsburgh, PA. 


\section{DEDICATION}

This project is dedicated to my dearest family and friends, who supported me throughout this process. Thank you for pretending, with varying degrees of conviction, that I would ever finish it. Love to you all! 


\section{ACKNOWLEDGEMENTS}

Special thanks to the following the individuals who helped me complete this project: Lindsey

Goodman, for giving me the idea and introducing me to Amy Williams, Amy for writing such a fabulous piece of music and for being so generous with sharing information; Francesca Arnone, Virginia Thompson, and Lynn Hileman for all taking turns as research advisors and committee chairs, and my committee for helping me make it to the other side. Special thanks to Robert Frankenberry for exploring First Lines with me through performances, and to Lindsey Goodman, Alberto Almarza, and Andrea Ceccomori for their insight concerning the ins and outs of learning the piece. 


\section{TABLE OF CONTENTS}

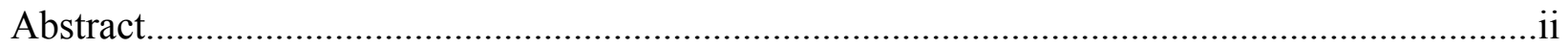

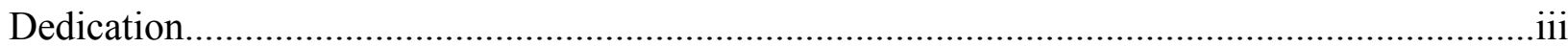

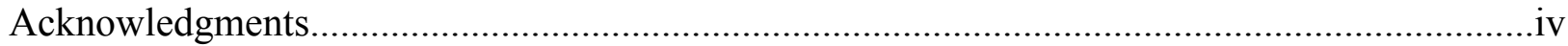

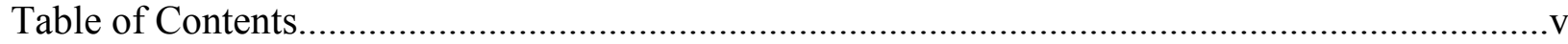

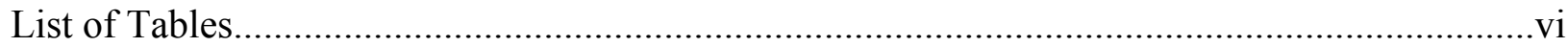

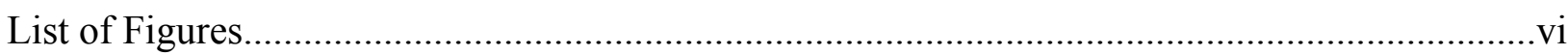

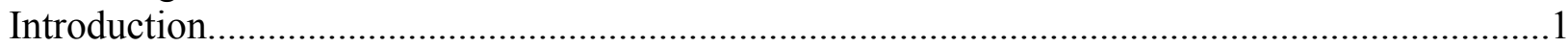

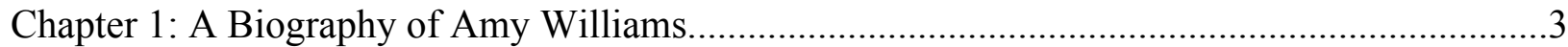

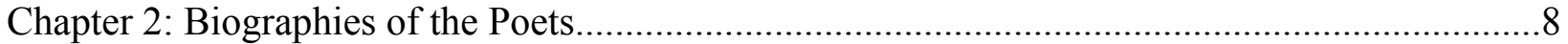

Chapter 3: The Relationship Between the Poetry and Music......................................................16

Chapter 4: Performance Suggestions for First Lines................................................................ 41

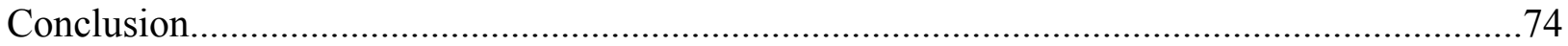

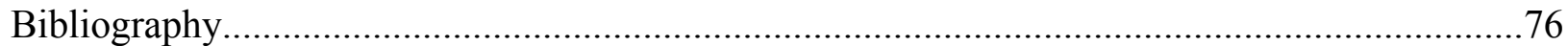

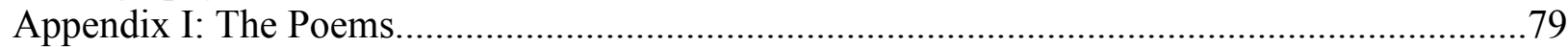

Appendix II: Transcript of an Interview with Amy Williams.................................................105

Appendix III: Biographies of Interviewed Flutists.................................................................127

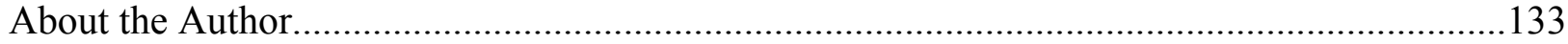

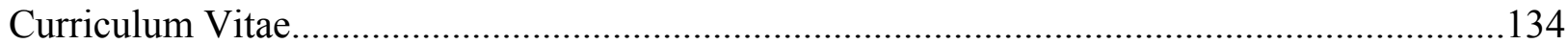




\section{LIST OF TABLES}

Table 1: Extended Techniques for Flute in First Lines.............................................................41

\section{LIST OF FIGURES}

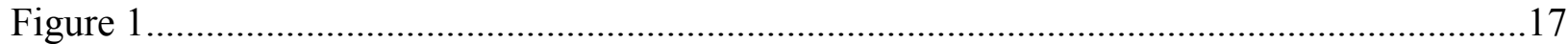

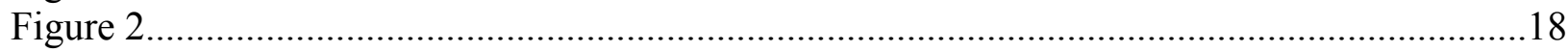

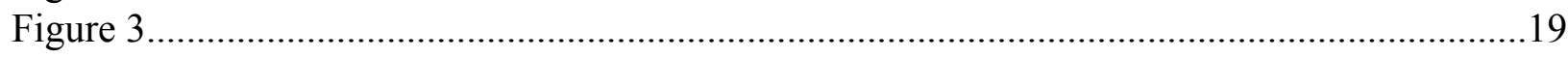

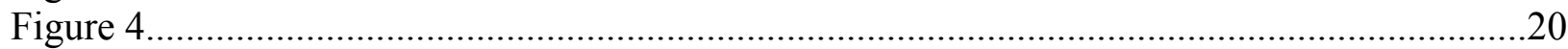

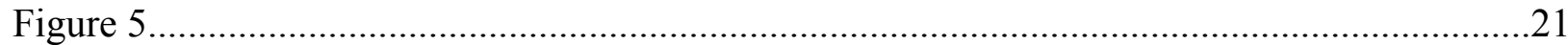

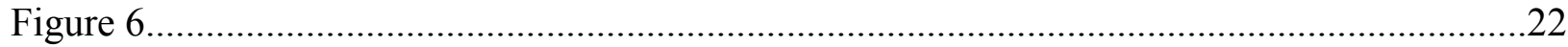

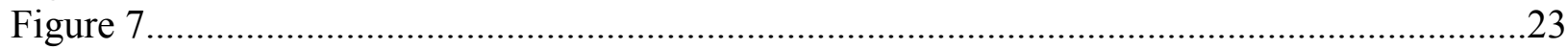

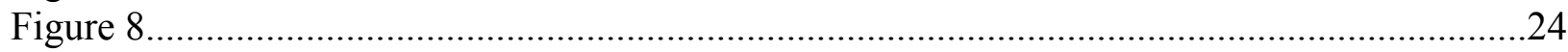

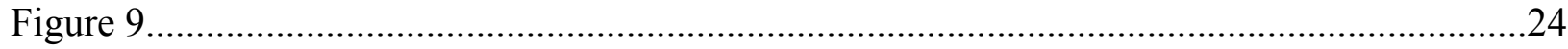

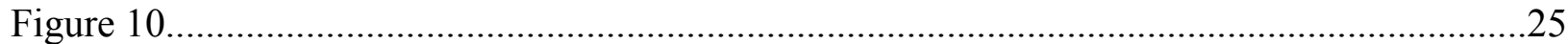

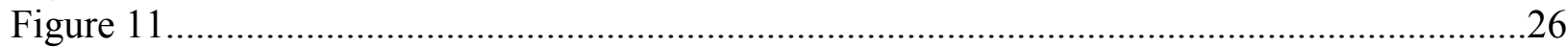

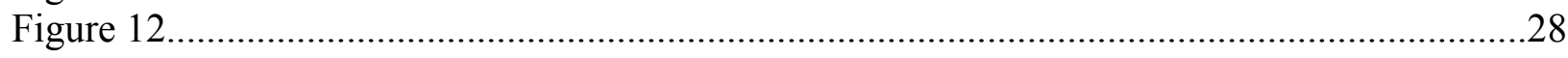

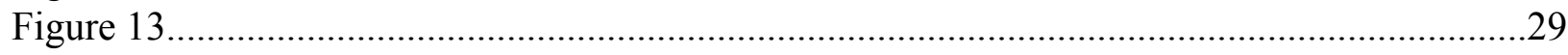

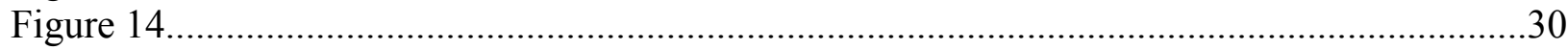

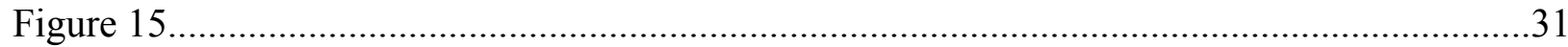

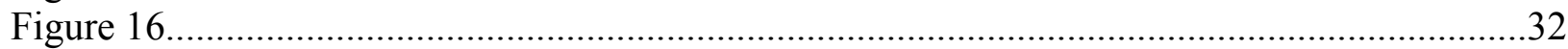

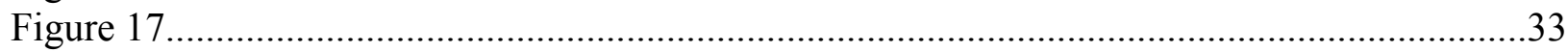

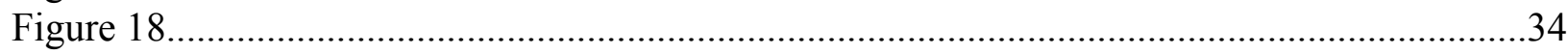

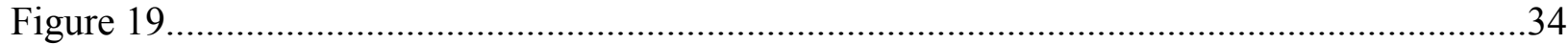

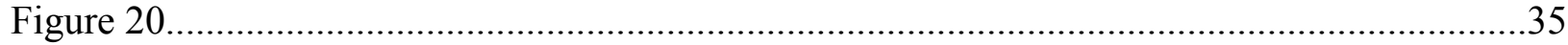

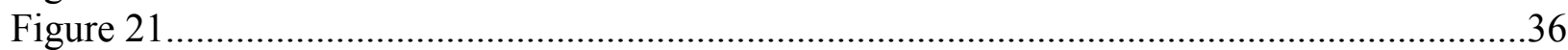

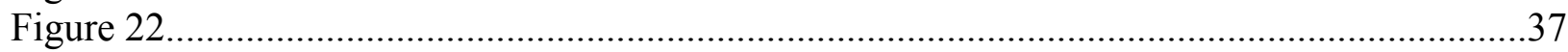

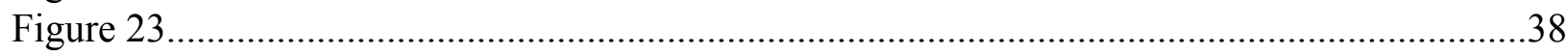

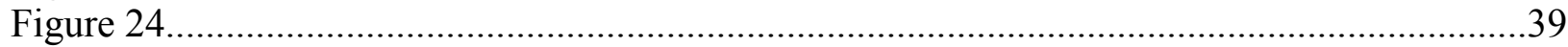

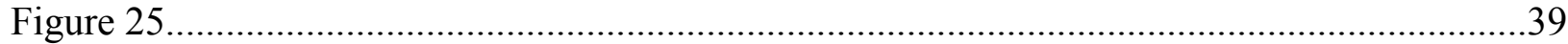

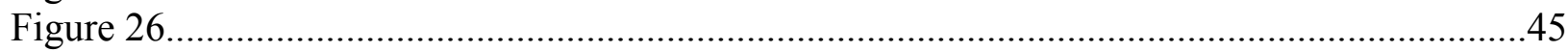

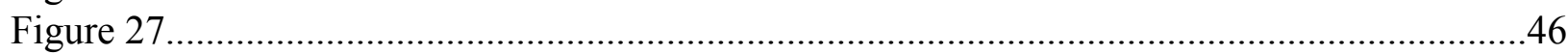

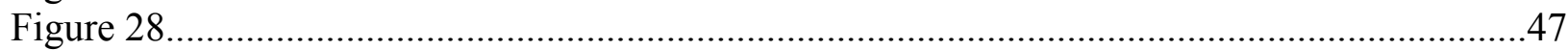

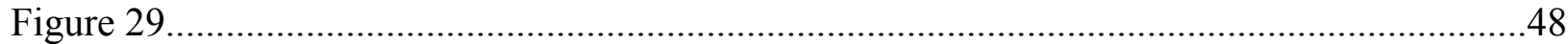

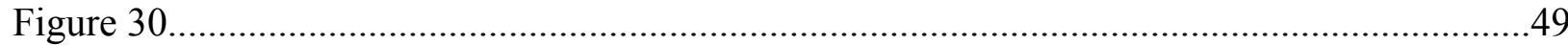

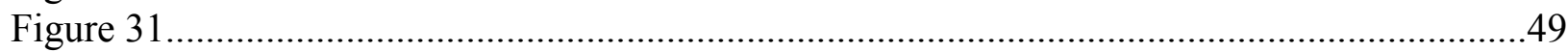

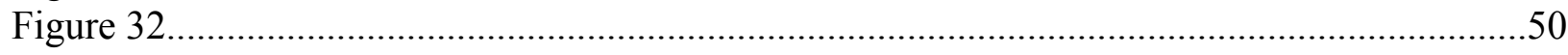

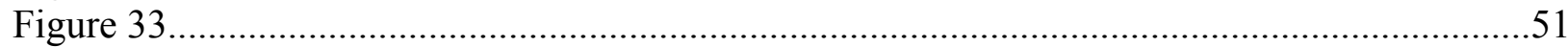

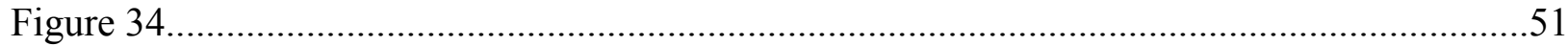

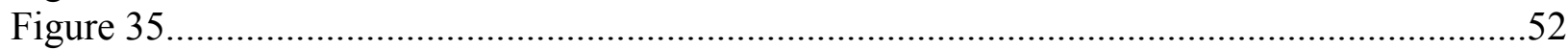

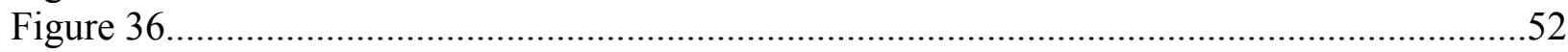

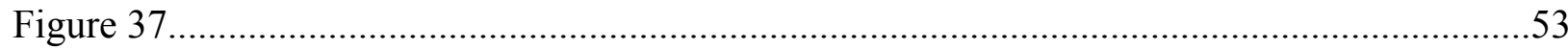

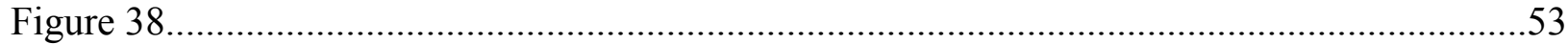

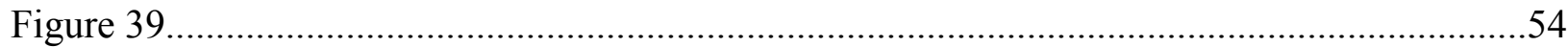

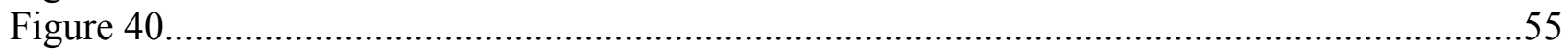




\section{LIST OF FIGURES (continued)}

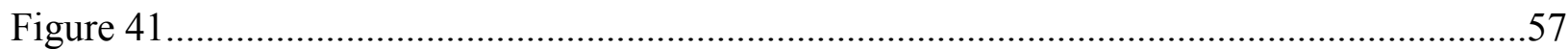

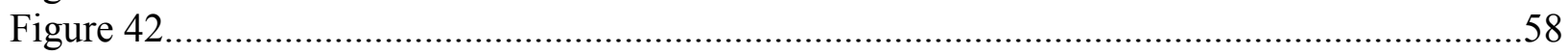

Figure 43 .

Figure 44

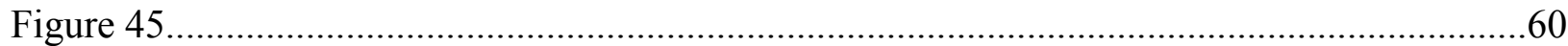

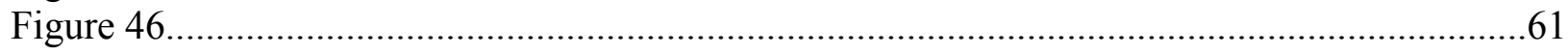

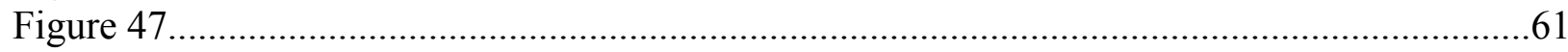

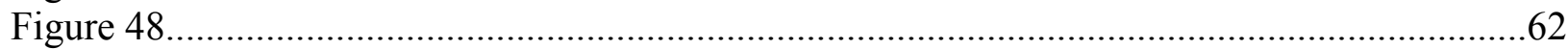

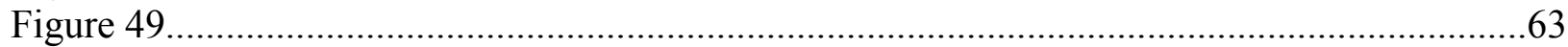

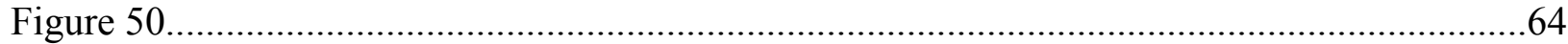

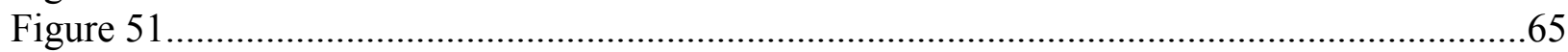

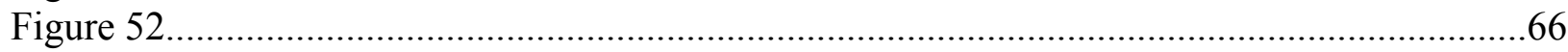

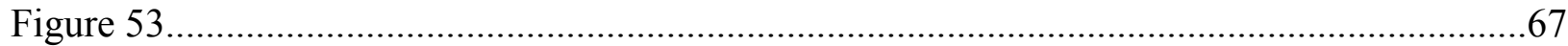

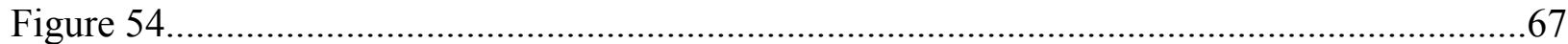

Figure 55

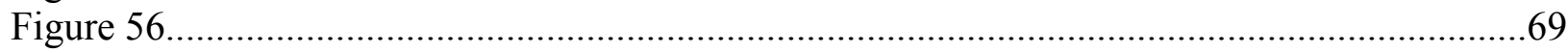

Figure 57

Figure 58 


\section{INTRODUCTION}

Amy Williams composed First Lines in the spring of 2006, during her residency at the Bellagio Center in Lake Como, Italy. While at the Center, Williams began searching for inspiration and discovered books of poetry with titles suggestive of music and time. ${ }^{1}$ According to the composer, "I began reading these books and I was struck by the ability of a strong poem to instantly pull the reader in, to create a richly developed atmosphere in the very first line. I began to imagine how this same effect could be achieved with music."

Williams' goal in composing these eleven miniatures was to have each movement musically reflect the character of its related poem. The different aesthetic of each movement reflects her compositional approach, which is an amalgam of post-serialist musical styles. Williams studied flute from elementary school through college, and she has stated that because of this, the flute is the instrument she feels the most comfortable writing for aside from the piano. Her earlier training in flute gave her "a wide palette of techniques to choose from,"” and the confidence to explore "the possible range of colors and sounds" for the instrument. ${ }^{4}$

Flutist Lindsey Goodman says that Williams possesses an "amazing ability as a colorist," ${ }^{, 5}$ and throughout her catalogue, timbral effects are accomplished through the use of extended techniques. The term extended techniques refers to any non-traditional method of producing sound on a musical instrument. ${ }^{6}$ An early example of their use in solo repertoire appeared in 1936 when Edgar Varèse utilized key clicks in Density 21.5. In the twentieth and

\footnotetext{
${ }^{1}$ Amy Williams, interview by author, phone, Pittsburgh, PA 3 February 2010.

${ }^{2}$ Ibid.

${ }^{3}$ Ibid.

${ }^{4}$ Ibid.

${ }^{5}$ Lindsey Goodman, interview by author, Skype, Pittsburgh, PA 4 January 2014.

${ }^{6}$ The alternative term "contemporary techniques" is becoming more widespread as these techniques become integrated into current instrumental practice, but "extended techniques" will be used in this document, as it is still the most commonly used term in the flute community.
} 
twenty-first centuries, these techniques have been further explored and developed by composers such as Williams, along with Robert Dick, Robert Aitken, and Ian Clarke.

Numerous method books and dissertations pertaining to these techniques have been published. The rising popularity of works utilizing extended techniques, as well as the abundance of general pedagogical research on the subject, indicates that such works have found their way into the standard flute repertoire. In the introduction to Tone Development Through Extended Techniques, Robert Dick writes "we are in a time of growth and change for the flute, a time when limitations, both technical and conceptual, are being left behind...and an important goal is for the player to integrate the immense capacities of the instrument into a coherent whole in which all parts support and strengthen one another." ${ }^{, 7}$ The author hopes that a performance guide specific to the techniques required in First Lines will lead to the inclusion of it, and other similar pieces, into personal repertoires.

\footnotetext{
${ }^{7}$ Robert Dick, Tone Development Through Extended Techniques (St. Louis: Multiple Breath Music, 1986),
} 7. 


\section{CHAPTER 1: A Biography of Amy Williams}

Composer Amy Williams "went into the family business." "8 Born in Buffalo, NY in 1969, Williams is the daughter famed percussionist Jan Williams and violist Diane Williams, a former member of the Buffalo Philharmonic Orchestra. Three of her four grandparents played piano at varying levels of proficiency. Music was a large part of her daily life in childhood, as she attended orchestra rehearsals with her mother, observed string quartet rehearsals in the living room on weekends, and interacted with the myriad of composers and performers her father hosted while organizing festivals and concerts during his tenure at the State University of New York (SUNY) Buffalo. ${ }^{9}$ Morton Feldman and John Cage were houseguests on more than one occasion during Williams' childhood. ${ }^{10}$

After four years of studying piano, Williams began her flute study around the age of eight. Her older sister played the cello, and Williams wanted to avoid carrying a large instrument on the school bus, an early indication of the pragmatism that guides Williams' work today. ${ }^{11}$ Her first flute teacher was Robert Dick, who was at that time a Creative Associate at SUNY Buffalo. Their flute lessons incorporated classical repertoire, but Dick also taught Williams to play whistle tones and other extended techniques. Very soon she could play Chopsticks in multiphonics, ${ }^{12}$ and Williams shared that "if Robert had stayed in Buffalo I would be a flutist today." "13 Williams continued flute lessons after Dick left Buffalo, and played flute through

\footnotetext{
${ }_{9}^{8}$ Amy Williams, interview by author, in person, Pittsburgh, PA 24 January 2014.

${ }^{9}$ Ibid.

${ }^{10}$ Ibid.

${ }_{12}^{11}$ Ibid.

12 "Biography," Amy Williams Music, http://amywilliamsmusic.com/biography/ [accessed 8 November 2014].

${ }^{13}$ Williams, interview by author, 24 January 2014.
} 
college until composition and piano study, in conjunction with other interests in theatre, philosophy and French, left little time to focus on the flute. ${ }^{14}$

The first thing Williams ever composed was her high school senior class song. ${ }^{15}$ After graduating from high school, Williams attended Bennington College, a small liberal arts school in Vermont where she studied composition with Lou Calabro. Bennington provided a supportive environment for Williams, and she maintains that if she had attended a conservatory, she would not be a musician today: ${ }^{16}$ "There was something special about Bennington for me, it was a liberal arts college... I was the only pianist. I felt special there, and I wasn't writing my solo clarinet piece when there were others in the class who had already written symphonic works." ${ }^{17}$

After graduation, Williams taught public school for two years while also pursuing piano performance and composition, then spent a fellowship year studying composition with Sven Nielson in Denmark. ${ }^{18}$ After this, it was a challenge to find a graduate program that would allow Williams to earn degrees in both composition and piano performance, ${ }^{19}$ but the opportunity to do so presented itself back at SUNY Buffalo. There, Williams studied piano with long-time family friend Yvar Mikhashoff, a specialist in contemporary piano repertoire, and composition with David Felder.

Williams stayed at SUNY Buffalo to complete a doctorate in composition, and during this time she studied with both Nils Vigeland and Charles Wuorinen. Williams continued her piano study with Mikhashoff until his death in 1993, after which she studied with Stephen Manes

\footnotetext{
${ }_{15}^{14}$ Williams, interview by author, 24 January 2014.

${ }^{15}$ Ibid.

${ }^{16}$ Ibid.

${ }^{17}$ Ibid.

${ }^{18}$ Ibid.

${ }^{19}$ Ibid.
} 
and Alan Feinberg. During these years, Williams met fellow pianist Helena Bugallo, with whom she formed the Bugallo-Williams Piano Duo.

Williams began her academic teaching career by returning to Bennington College in 1998 as a member of the music faculty before moving to a position at Northwestern University in 2000. She was recently named Associate Professor of Composition at the University of Pittsburgh, where she joined the faculty in $2005 .^{20}$ The Bugallo-Williams Piano Duo is constantly in demand. The pair has performed throughout Europe and the Americas at such prestigious venues as the Miller Theatre, Symphony Space, and Le Poisson Rouge in New York, ${ }^{21}$ and as a part of the following concert series and festivals: Musica Contemporanea Ciclos de Conciertos (Buenos Aires), Festival Attacca (Stuttgart), Palacio de Bellas Artes (Mexico City), Warsaw Autumn Festival, Cologne Triennale, and Wittener Täge für Neue Kammermusik. $^{22}$ Williams' discography is an extensive collection of contemporary piano works, and The Bugallo-Williams Piano Duo's debut CD, released in 2004, consists of Conlon Nancarrow's complete music for solo piano and piano duet. The Nancarrow recording was followed by music of Stravinsky in 2007, and the music of Morton Feldman and Edgar Varèse in 2009. The duo's recording of the complete piano duets of György Kurtág were released in $2014 .^{23}$

Williams' compositions have been programmed at renowned contemporary music festivals in the United States and abroad, including Ars Musica (Belgium), Gaudeamus Music Week (Netherlands), Dresden New Music Days (Germany), ${ }^{24}$ and Tanglewood Festival of

\footnotetext{
20 "Biography," Amy Williams Music.

${ }^{21}$ Amy Williams, "Academic Curriculum Vitae," (September 2014).

22،"Biography," Amy Williams Music.

${ }^{23}$ Williams, "Academic Curriculum Vitae."

24 "Biography," Amy Williams Music.
} 
Contemporary Music. Her works have been performed by such groups as the Pro Arte Chamber Orchestra, JACK Quartet, Pittsburgh New Music Ensemble, and the International Contemporary Ensemble (ICE) ${ }^{25}$ Recordings of her compositions can be heard on the Parma, VDM (Italy), Blue Griffin and New Ariel labels. ${ }^{26}$ A collection of recent solo and chamber works, entitled Crossings: Music for Piano and Strings, was released by Albany Records in April 2013. ${ }^{27}$

Williams is also the recipient of numerous awards, winning the Wayne Peterson Composition Prize for Sextet, the Audio Inversions Composition Prize for Cineshape 1, and an ASCAP Award for Young Composers for verre-glaz, among others. ${ }^{28}$ Grants from the American-Scandinavian Foundation, American Music Center, Greater Pittsburgh Arts Council, Pro Musica Viva (Germany), Meet the Composer, the Heinz Endowments and the Pittsburgh Foundations have supported her compositional endeavors, and she received the Howard Foundation Fellowship for 2008- 2009 and a 2009 Fromm Music Foundation Commission to write a piece for the JACK Quartet. ${ }^{29}$ She has also served as Assistant Director of June In Buffalo, Director of New Music Northwestern, and is currently on the artistic board of the Pittsburgh-based concert series, Music on the Edge.

Williams maintains that she is nothing if not practical. ${ }^{30}$ Because she is both a composer and a performer, she possesses a "pragmatism that comes with being a performing musician." ${ }^{31}$ "Intrigued by issues of chamber music," ${ }^{32}$ Williams is always considering the performer's point of view. She shares that when "writing for a chamber group, I'm thinking about the dynamic of

\footnotetext{
${ }^{25}$ Williams, "Academic Curriculum Vitae."

26 "Biography," Amy Williams Music.

${ }^{27}$ Williams, "Academic Curriculum Vitae."

28 "Biography," Amy Williams Music.

${ }^{29}$ Williams, "Academic Curriculum Vitae."

${ }^{30}$ Williams, interview by author, 24 January 2014.

${ }^{31}$ Ibid.

${ }^{32}$ Ibid.
} 
interaction, what challenges there are rhythmically, in terms of ensemble issues." ${ }^{33}$ Williams considers the musicians' strengths and the types of sounds she can "exploit.",34

Although Williams has written for large ensemble (most recently the Pittsburgh Symphony Orchestra gave the world premiere Flood Lines) she contends that she is drawn to composing chamber music, at least partly for reasons of practicality. ${ }^{35}$ It is less difficult to organize performances of chamber music than to have works performed by symphony orchestras. ${ }^{36}$ This practicality also directs Williams' pedagogical approach to composition. She conveys this episode from a recent interaction with a student:

I just had a lesson with a student who brought in a wonderful sound effect for the violin but with scraping a metal ruler on the strings. I said, 'This is not practical. As a performer I will not do something that hurts my instrument. Unless you are supplying the string quartet with four instruments and four bows, this is not practical.' $^{\text {, }}$

For more information on Williams, consult Appendix II or visit www.amywilliamsmusic.com.

${ }^{33}$ Williams, interview by author, 24 January 2014.

${ }^{34}$ Ibid.

${ }^{35}$ Ibid.

${ }^{36}$ Ibid.

${ }^{37}$ Ibid. 


\section{CHAPTER 2: Biographies of the Poets}

Brief biographies of the poets are included in this chapter to help the performer gain a comprehensive understanding of First Lines.

\section{Marilyn Chin}

Poet Marilyn (Mei-Ling) Chin was born in Hong Kong in 1955 and moved to Oregon with her family shortly thereafter, becoming United States citizen in 1967. Her works include three volumes of poetry: Rhapsody in Plain Yellow (2002); The Phoenix Gone, The Terrace Empty (1994); and Dwarf Bamboo (1987); a novel entitled The Revenge of the Mooncake Vixen (2009), and her poems appear in several anthologies, including The Norton Anthology of Modern and Contemporary Poetry. She has also worked as a translator of Chinese and Japanese poets. Chin currently teaches at the University of San Diego, and is in frequent demand as a guest speaker. Chin holds a Bachelor of Arts degree from University of Massachusetts, Amherst, and a Master of Fine Arts degree from the University of Iowa, and is the recipient of numerous awards.

Assimilation is a major theme in Chin's poetry. ${ }^{38}$ In her first book, The Phoenix Gone, The Terrace Empty, Chin shares the story behind the Americanization of her name. ${ }^{39}$ In "How I Got That Name: An Essay on Assimilation," Chin writes of her father's infatuation with Marilyn Monroe, and how "obsessed with a bombshell blonde / transliterated 'Mei Ling' to 'Marilyn,"

\footnotetext{
38 "Marilyn Chin," The Poetry Foundation, http://www.poetryfoundation.org/archive/poet.html?id=81896 [accessed 10 November 2011].

${ }^{39}$ Ibid.
} 
he gave his daughter the name of "some tragic white woman / swollen with gin and Nembutal."40

In Chin's entry in Contemporary Women Poets, Anne-Elizabeth Green says the following:

Chin does indeed carry a doubled consciousness. She is able in her poetry to articulate skillfully that interplay of, and tension between, cultures, which constitutes her experience of the world. A critical part of this process of articulation includes establishing links and continuities between an ancestral past and cultural history, and an American present. ${ }^{41}$

In Rhapsody in Plain Yellow, Chin "elegizes the loss of her mother and maternal grandmother and tries to unravel the complexities of her family's past." ${ }^{42}$ According to C. L.

Chua,

The image of yellow in the title alludes to the author's Chinese ancestry but it also points to the effects of aging, to the privileges and perils attendant on that color (from precious metals to alluring blondes), and to William Carlos Williams' use of yellow in his 1917 poem "Love Song." 43

From Rhapsody in Yellow, Williams included the following poems:

"That Half is Almost Gone"

"Hospital in Oregon"

"Family Restaurant \#2"

"Horseyear"

${ }^{40}$ Marilyn Chin. "How I Got that Name," Poets, http://www.poets.org/viewmedia.php/prmMID/15631 [accessed 16 August 2012].

41 Anne-Elizabeth Green, "Marilyn Chin," in Contemporary Women Authors, ed. Pamela Shelton, 62-65 (Detroit, MI: St. James Press, 1998).

${ }^{42}$ Marilyn Chin, Rhapsody in Plain Yellow: Poems (New York: W.W. Norton, 2002), jacket notes.

${ }^{43}$ C. L. Chua, "Rhapsody in Plain Yellow," Magill's Literary Annual 2003 (June 2003) : 1-3. http://web.ebscohost.com [accessed August 16, 2012]. 


\section{Toi Derricote}

Toi Derricotte was born in Hamtramck, Michigan in 1941, and received her Bachelor of Arts degree in Special Education from Wayne State University and a Master of Arts degree in English Literature from New York University. She is currently on the faculty at the University of Pittsburgh. Together with poet Cornelius Eady, Derricotte founded Cave Canem in 1996, a writing workshop for African-American poets.

As an "African American feminist poet, Derricotte speaks from a position particularly attuned to American culture's racism and sexism." ${ }^{\text {44 }}$ Her writings include four published volumes of poetry: Tender (1997); Captivity (1989); Natural Birth (1983); and The Empress of the Death House (1978). Her prose memoir, The Black Notebooks, won the 1998 Anisfield-Wolf Book Award for Non-Fiction and was a New York Times Notable Book of the Year.

In the introduction to The Black Notebooks: An Interior Journey, Derricotte states the following:

These things drive my writing: the insistence on clarity - not only clarity in form and language, but clarity in embodying our human nature, our 'truth'- and on the integral connection between beauty, function, and drama. I want the eye of the reader, as in a house surrounded by beautiful and dramatic views, to be drawn away from the 'house' itself, away from the writing, to what is around it. ${ }^{45}$

Derricotte's autobiographical style reflects the "universal subjects of racism and identity in ways that are moving, painful, and illuminating. ${ }^{, 46}$ Her poetry explores these themes along with others, including the interaction between African-American women and the surrounding

\footnotetext{
${ }^{44}$ Martha Smith and Leah Sparks, “Toi Derricotte," Novel Guide (2010) http://www.novelguide.com/a/discover/aww_01/aww_01_00305.html [accessed 12 September 2010]. ${ }^{45}$ Toi Derricotte, The Black Notebooks: An Interior Journey (New York: W.W. Norton, 1997), 19. 46 “Toi Derricotte: Biography," The Poetry Foundation, http://www.poetryfoundation.org/ archive/poet.html?id=81170\#bibliography [accessed September 18, 2010].
} 
world and the nature of love, sexuality, and violence. ${ }^{47}$ Her influences include Sylvia Plath and Billie Holliday, women she considers to have had a "voice that comes from what we experience that goes beyond what we live."48

Some of this private self was revealed in Derricotte's third collection of poems, entitled Captivity. The central theme of this volume centers on the "vestiges of slavery in the lives of contemporary African Americans, including the prevalence of violence in the family, and the continued abuses of racism within the society." ${ }^{49}$ Captivity is divided into four sections: "Blackbottom," "Red Angel," "The Testimony of Sister Maureen," and "The Terrible Bright Air." The "Blackbottom" poems deal with Derricotte's childhood in Michigan, while "Red Angel" is examination of problems encountered in her adulthood. "The Testimony of Sister Maureen" is based on the trial of a teaching nun with the Sisters of St. Joseph, who was accused of murdering her newborn son. The final section, "The Terrible Bright Air" is more varied, with poems about Allan Ginsberg and Walt Whitman, as well as race and death.

From Captivity, Williams chose to the following poems:

"For the Dishwasher at Boothman's,"

"The Testimony of Sister Maureen"

\section{Patricia Goedicke}

Patricia Goedicke (1931-2006) graduated from Middlebury College in 1953, where she was a student of Robert Frost. In total, 13 volumes of Goedicke's poetry have been published,

\footnotetext{
47 “Toi Derricotte: Biography” The Poetry Foundation.

${ }^{48}$ John Eastman, "Poet Toi Derricotte," Black and White: Interviews, Essays, and Reports, 1998, http://blackandwhiteprogram.com/interview/poet-toi-derricotte [accessed September 18, 2010].

49 "Toi Derricotte: Biography," The Poetry Foundation.
} 
including King of Childhood (1984), The Wind of Our Going (1985), and The Tongues We Speak (1989). As a young woman, Goedicke was an avid skier, and her work contains references to sporting activities, including her posthumously published volume Baseball Field at Night and a poem Williams used in First Lines, "The Athlete." After a long career in higher education, Goedicke retired from teaching at the University of Montana in 2003. An active member of the writing community there, she participated in The Rattlesnake Ladies' Writing Salon, formed 'to give Missoula's women writers a community of camaraderie and criticism away from students and faculty, from stalwart husbands—and from fishing stories." ${ }^{, 50}$

Goedicke said the following about her poetry:

I write to set myself and perhaps a few others free: free politically in the sense that the process of "sharing" the private views of reality each of us sees from the separate hotel room windows of our lives is part and parcel of the assertion-indeed even a validation--of the very idea of community; and free spiritually in the sense that the intensity of poetry's concentration on the already deeply metaphorical character of language is chiefly important for the way it enables the individual, apparently incorporeal psyche to move back and forth between the material world of exterior reality and the invisible, eternally isolated interior world of the self. ${ }^{51}$

According to Contemporary Poets, Goedicke's themes include "myth and dreams, childhood fantasies, the I-Thou relationship wherever it is found (be it in marriage, friendship, or the larger community), and the issue of paradise and hell in human experience." ${ }^{32}$

From Listen, Love, Williams chose to use the following poems:

\footnotetext{
50 "Biographical Note," Guide to the Patricia Goedicke and Leonard Wallace Robinson Papers 1910-2006, bulk 1931-2006, Northwest Digital Archives, http://nwda-db.wsulibs.wsu.edu/ark:/80444/xv43658 [accessed 27 January 2011].

51 David Ray, "Patricia Goedicke," Contemporary Women Poets, ed. Pamela Shelton (Detroit : St. James, 1997), 135.

52 "Patricia Goedicke," Contemporary Poets, Literature Resource Center. http://go.galegroup.com. www.libproxy.wvu.edu/ps/i.do?\&id=GALE\%7CK1660001035\&v=2.1\&u=morg77564\&it=r\&p=LitRC\& $\mathrm{sW}=\mathrm{w}$ [accessed 28 January 2011].
} 


\author{
"The Athlete" \\ "Chaplinesque (2)" \\ "The Princes of Heaven"
}

\title{
Colleen McElroy
}

Colleen McElroy was born in St. Louis, Missouri in 1935, and began her "romance with language" ${ }^{53}$ while listening to radio show recordings on her grandmother's Victrola. When asked about her early fascination with storytelling, McElroy shared the following:

$[\mathrm{M}] \mathrm{y}$ mother had several sisters and they were all storytellers. They would gather at my grandmother's house--sometimes having dinner and sometimes just to come over to see how she was doing--and I would hide under the dining-room table and listen to them until they caught me and made sure I was out of the room. Some evenings, my grandfather would come home from work and read to me, but after he died in the mid-'40s, I was likely to go into the attic and listen to records on my grandmother's wind-up Victrola. These were records from at least a decade earlier, and I mimicked conversations. So I spent a lot of time alone, and the storytelling became a part of me, both the way I was educated as well as the way I was amused. Most of my early poems were narratives, and I still prefer narrative poetry. $^{54}$

Although she was a writer from an early age, McElroy first pursued a career that focused on

speech, hearing, and language patterns, only beginning a writing career in earnest in the early 1970s.

McElroy's father was in the United States Army, and the family traveled the world as he was moved from post to post. These travels inspired much of McElroy's writing, as she herself

\footnotetext{
53 ,"Colleen J. McElroy,” The Poetry Foundation, http://www.poetryfoundation.org/bio/colleen-j-mcelroy [accessed September 23, 2011].

${ }^{54}$ James L. Hill, "Out of St. Louie Into The World Unbound: an Interview with Colleen J. McElroy," African American Review 42, no. 2 (2008), 187 Literature Resource Center. http://go.galegroup.com/ps/i.do?\&id=GALE\%7CA199599245\&v=2.1\&u=ein_remote\&it=r\&p=LitRC\&s $\mathrm{w}=\mathrm{w}$ [accessed September 23, 2011].
} 
states "the experiences I have had as an Army dependent, traveling with my father and growing up in St. Louis, are essential to understanding the experiences I have as an adult, as an intrepid traveler." ${ }^{55}$ Much of her poetry and other writings draw on her extensive travel to Europe, South America, Japan, Majorca, Africa, and Southeast Asia.

In addition to more than ten volumes of poetry, McElroy's works include plays, short stories, and photojournalistic works. From her volume Traveling Music, Williams included the following poem:

"Caution: This Woman Brakes for Memories"

\section{Ol'ga Sedakova}

Russian poet Ol'ga Sedakova was born in 1949 in Azarovka, a village near Moscow, Russia. Sedakova encountered censorship at an early age, when her teacher edited one of her poems "to make it conform more closely with currently accepted Soviet literary conventions."

During her childhood, Sedakova's grandmother shared stories of Russian folklore, as well as old Russian Orthodox prayers, lending elements of Russian culture and religious subtext to Sedakova's work. Additionally, Sedakova's appreciation for music presents itself in her poetry. According to biographer Valentina Polukhina, Sedakova was inspired by composers including Frédéric Chopin, and the poet "experiments freely with rhythm, and music plays an important role in the general semantic and rhythmical conception of her verse." ${ }^{, 57}$ Other themes in Sedakova's poetry include the four elements of water, earth, fire, and air. Sedakova claims,

\footnotetext{
${ }^{55}$ Ibid.

${ }^{56}$ Valentina Polukhina, "Olga Sedakova: Russian Poets of the Soviet Era," Russian Poets of the Soviet Era 359 (2011), http://go.galegroup.com/ps/i.do?\&id=GALE\%7CH1200014175\&v=2.1\&u=ein remote\&it=r\&p=LitRC\&sw=w [accessed September 16, 2011].

${ }^{57}$ Ibid.
} 
"My favorite element was water: static or flowing, it drew me like a magnet. The sight, the sound, the touch, even the smell., 58

During Sedakova's childhood, the Communist party in Russia was doing everything in its power to eradicate folk culture, religion, and Western art in its pursuit of Communism. Committed to maintaining her independent voice, Sedakova elected to publish her poetry in samizdat, books published and distributed outside of the mainstream Soviet newspapers and journals. It was only after Mikhail Gorbachev took power and instituted the policy of glasnost, effectively dissolving the lines between official and underground culture, that Sedakova's work moved into the mainstream.

Leaving her home country for the first time at age of forty, Sedakova recollects:

Before the end of 1989 I had not traveled outside the borders of the U.S.S.R.; indeed it was absurd to imagine that I could. My first meeting with Europe (for me it was Scotland) was a real shock, both a happy one and a painful one. But really, these first meetings with Britain, Italy, France, Germany--with that world of ours, it seemed, hopeless love, with the world on the other side--I still would call the third happy time of my life. ${ }^{59}$

It was during a residency at Keele University in England that Sedakova published Silk in Time, the collection of bilingual poems used by Williams in First Lines.

From Silk in Time, Williams included these poems:

"Is that only the windows creaking, Maria"

"A Chinese Journey"

\footnotetext{
${ }^{58}$ Valentina Polukhina, "Excerpts from an Interview with Olga Sedakova," Modern Poetry in Translation, May, 1994, http://www.poetrymagazines.org.uk/magazine/record.asp?id=13272 [accessed September 16, 2011].

${ }_{59}$ Polukhina, "Excepts from an Interview."
} 


\section{CHAPTER 3: The Relationship Between Poetry and Music in First Lines}

First Lines was composed in 2006 while Williams was in residence at the Bellagio Centre in Lake Como, Italy ${ }^{60}$ Williams already had the idea to write a collection of miniatures, and one day she searched the Centre's library for poetry that inspired a "sonic image." ${ }^{\prime 61}$ Poems she chose for First Lines immediately drew her into a particular "time, place, mood, atmosphere, [or] a feeling and emotion." ${ }^{.62}$ The decision of which texts to include was made purely on the basis of Williams' reaction to the poetry and the musical ideas each poem inspired.$^{63}$ However, once she realized that one of the volumes was by Toi Derricotte, who also teaches at the University of Pittsburgh and was in residence at the Bellagio Centre at the same time, Williams was even more inclined to include lines from that particular poet. ${ }^{64}$

Williams finds miniatures interesting because they can be difficult to write: "If you have too much material, the piece can feel incomplete, like it needs to go on. So to write something that really feels complete in a short amount of time is very challenging. ${ }^{.65}$ In order to produce a sense of finality in each movement of First Lines, "something different or special happens at the end. ${ }^{.66}$ The phrases from these poems provided the framework to organize First Lines as collection of very short movements.

Chamber music is Williams' favorite musical genre, especially because she loves the "interaction and dynamic and energy that come from more than one person," ${ }^{67}$ and several of the poems used in First Lines center around a relationship between characters: the first movement

\footnotetext{
${ }^{60}$ Williams, interview by author, 3 February 2010.

${ }^{61}$ Williams, interview by author, 24 January 2014.

${ }_{63}^{62}$ Williams, interview by author, 3 February 2010.

${ }^{63}$ Williams, interview by author, 24 January 2014.

${ }^{64}$ Ibid.

${ }^{65}$ Ibid.

${ }^{66}$ Ibid.

${ }^{67}$ Ibid.
} 
depicts two people are having a difficult conversation in "For the Dishwasher at Boothman's,"68 the central character in "Hospital in Oregon" is demanding quiet from a noisy third party in Movement VI, and someone is asking "Is that only the window creaking, Maria?" in Movement $\mathrm{X}$. To communicate the ways that characters relate to one another in the poetry used through First Lines, Williams uses variations in timbre while exploring the rhythmic and registral relationship between the flute and piano, the two characters in the musical composition.

I. "I sit in front of him / and look him in the eye...",69

The character of the opening movement of First Lines is direct and assertive. According to Williams, "this poem captured a particular mood, and it's not a sweet mood. 'I sit in front of him and look him in the eye.' That could be dreamy, sensual, loving. For me, it was, 'we're going to talk about this.' I wanted something with that kind of energy." ${ }^{70}$ Williams achieves this compositionally through the incessant use of rhythm and articulation. The flute performs almost constant sixteenth notes (figure 1), while rhythmic interjections in the piano reinforce the declamatory power of the movement, as seen in measures 1 and 2 (figure 2).

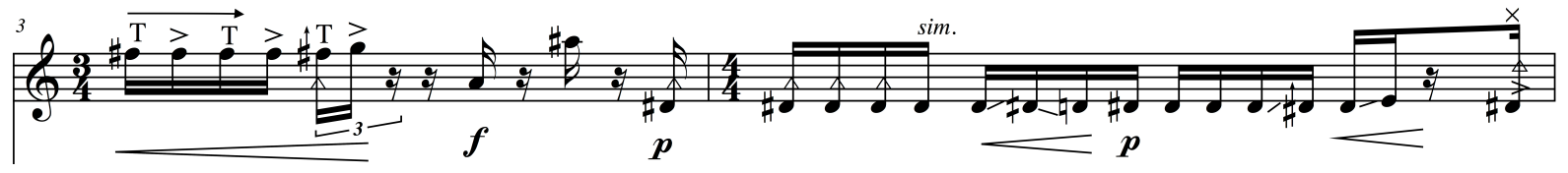

Figure 1

${ }_{68}^{68}$ Amy Williams, interview by author, in person, Pittsburgh, PA 24 January 2014.

${ }^{69}$ Toi Derricotte, Captivity (Pittsburgh, University of Pittsburgh, 1989), 58.

${ }^{70}$ Amy Williams, interview by author, in person, Pittsburgh, PA 24 January 2014. 


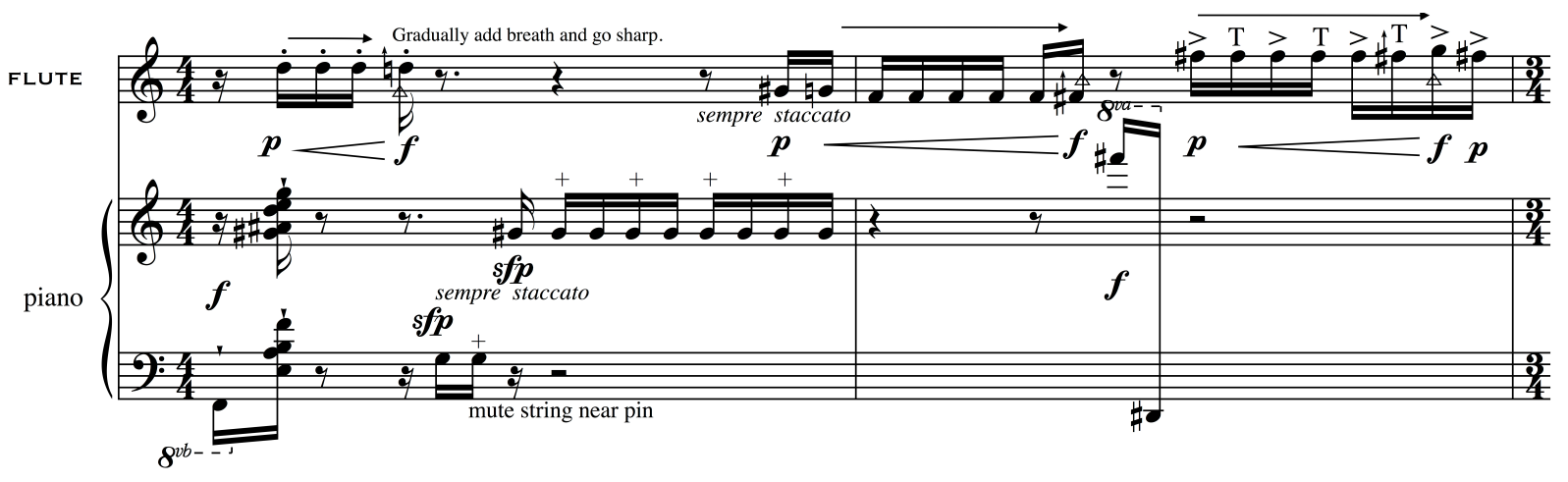

Figure 2

Williams also depicts the poem's character by employing timbral effects in both musical voices. Flutist Lindsey Goodman, who has studied First Lines extensively with Williams, suggests that the use of non-traditional tone colors underscores the movement's sense of disquietude. ${ }^{71}$ Williams herself has corroborated this interpretation, remarking that these details remove any sense of stability. ${ }^{72}$

The first example of this occurs in measures 1 and 2, where the flutist is instructed to "gradually add breath and go sharp,"73 use alternate fingerings to shade the color of adjacent sixteenth notes, and to move from a compact, centered tone to air only (see figure 2 ). In measures 5, 6, and 7, Williams adds key clicks in addition to the timbral change and elongates the transition from focused tone to a breathy sound, finally progressing to key clicks only in measure 7 (figure 3).

${ }^{71}$ Goodman, interview by author.

${ }^{72}$ Williams, interview by author, 24 January 2014.

${ }^{73}$ Amy Williams, First Lines, (Pittsburgh, Self-published, 2006), 2. 


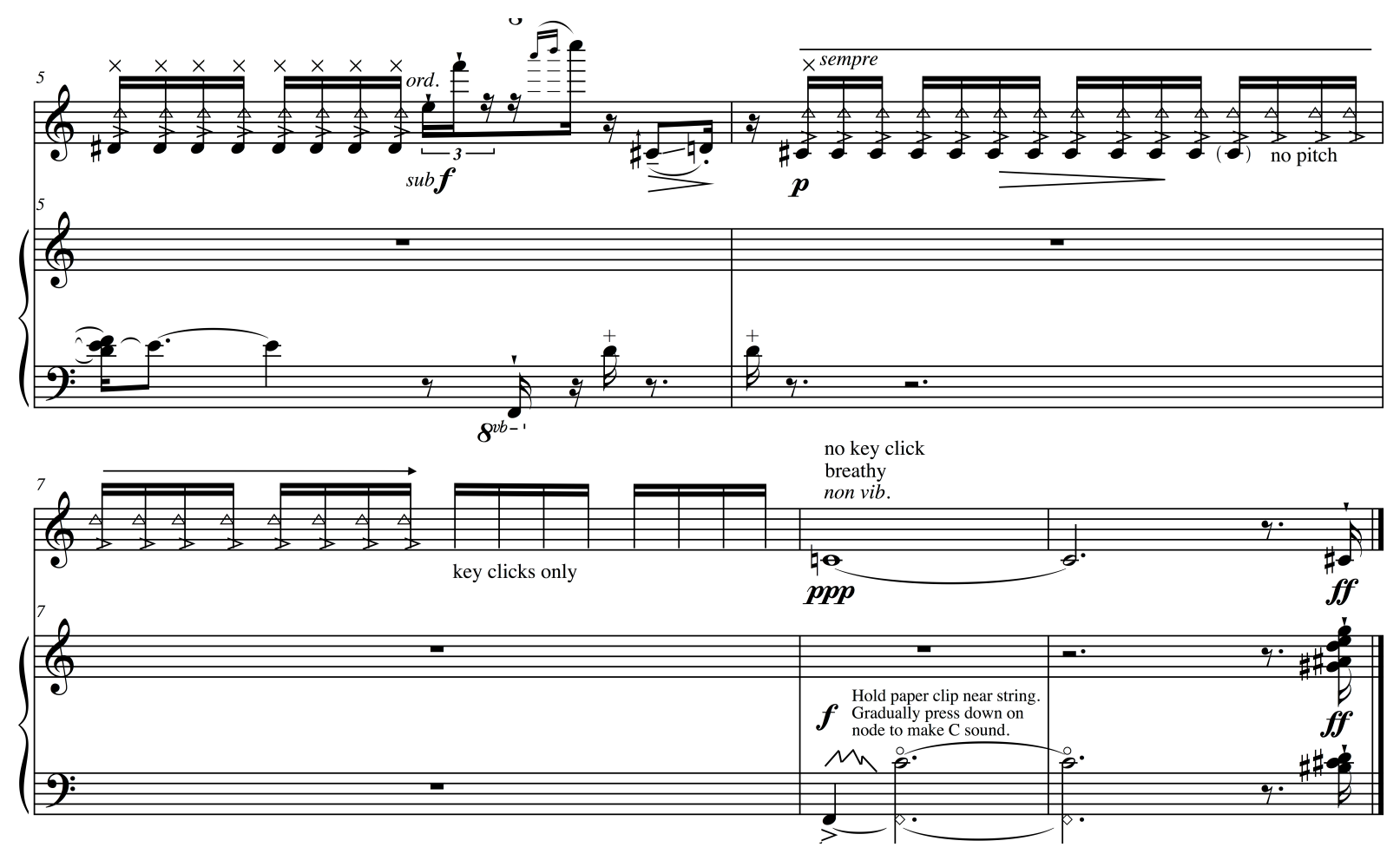

Figure 3

The composer states that in these measure, the two individuals in the poem begin to come to an understanding as movement's initial tension relaxes. ${ }^{74}$

To illustrate the difficulty of the conversation between the two characters in Derricotte's poem, Williams calls for the pianist to mute certain pitches, producing a sound devoid of any resonance and creating further tension (figure 2). At certain points, as in beat 3 of measure 5, the movement feels as if it could fall apart, an effect achieved by the use of hocket - a rhythmic device where two or more voices alternate pitches to create a composited melody - between the flute and piano (figure 3). However, the two instruments come together on the final pitch, which is unsettlingly placed on the final sixteenth note of the measure (see measure 9 in figure 3). Goodman's opinion is that at this point, the two characters "lock eyes and say 'now we're finally

\footnotetext{
${ }^{74}$ Williams, interview by author, 24 January 2014.
} 
going to get down to it.' This whole movement [is about] two people [who] are chasing each other around."75

II. "When the air is thin with frost / I blow rings of ice smoke...",76

Williams chose this particular text because it is "evocative of a sound... of something that dissipates." in measures 1 and 2 that diminuendo and use a flute tone that is "breathy throughout, so even 'normal' notes have a bit of breathiness" Goodman, creates a cold and icy sound quality. ${ }^{80}$

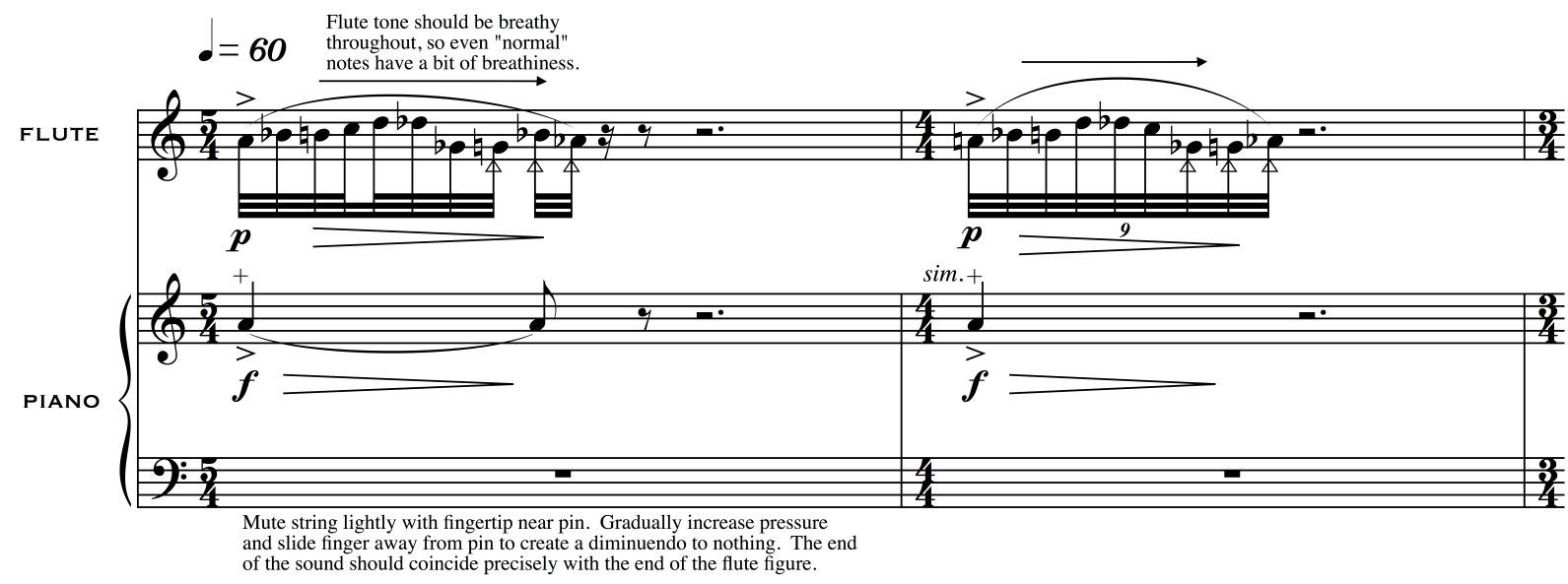

Figure 4

The flute takes the musical lead in this miniature, while the piano's role is less active. In the first two measures, the piano doubles the first note of the flute while muting the string near the pin. This, along with the subsequent diminuendo al niente with the flute (see figure 4)

\footnotetext{
${ }_{76}^{75}$ Goodman, interview by author.

${ }^{76}$ Colleen J. McElroy, Travelling Music (Ashland, Story Line, 1998), 87.

${ }_{78}^{77}$ Williams, interview by author, 24 January 2014.

${ }_{79}^{78}$ Ibid.

${ }_{80}^{79}$ Williams, First Lines, 3.

${ }^{80}$ Goodman, interview by author.
} 
supplements the sense that the sound is evaporating, according to Williams. ${ }^{81}$ She uses rhythm to propel the music forward and create intensity, as the group of 8 pitches on beat 1 of measure 1 becomes a group of 9 on beat 1 of measure 2 (figure 4 ).

Between measures 3 and 4, Williams creates the ice ring in reverse, with a flute crescendo instead of a diminuendo (figure 5).

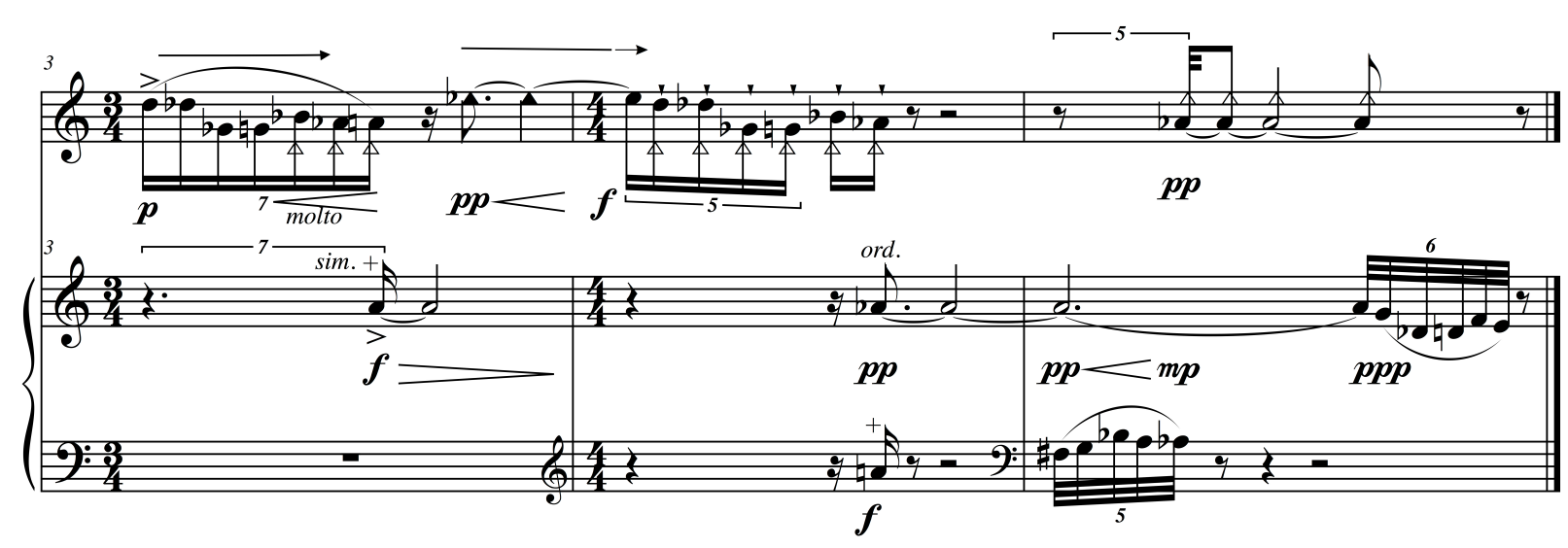

Figure 5

To reinforce this image, the piano attack occurs at the end of the gesture in measure 4 , rather than at the beginning as in the first two iterations of this idea. ${ }^{82}$ By employing this reversal, Williams avoids using the same figuration three times in exactly the same manner and creates variety within the 5 measures of Movement II. ${ }^{83}$

The piano is most active in the final measure, with two quick figures that dissolve as the movement closes at pianissimo (measure 5 in figure 5). This is a technique Williams uses throughout First Lines: she often writes something different or new to complete each miniature. ${ }^{84}$ In this instance, the final measure marks the first time the piano plays with an

\footnotetext{
${ }_{81}^{81}$ Williams, interview by author, 24 January 2014.

${ }^{82}$ Ibid.

${ }^{83}$ Ibid.

${ }^{84}$ Ibid.
} 
ordinary sound in this movement, and the change of timbre provides a marked contrast to the muted technique used throughout the other 4 measures and creates a sense of finality at the end of the movement. ${ }^{85}$

III. "the air hums at night / the wings of bees / beg for entrance at my ears... ",86

A 1976 trial in which a Catholic nun is accused of murdering her newborn child provides the narrative for Derricotte's poem The Testimony of Sister Maureen, and text from this poem is used in the third movement of First Lines. Sister Maureen was found not guilty of murder following evaluations by psychiatrists, who found her to be mentally unstable. Derricotte's long poem explores the anguished mental state of its central character, and uses colorful imagery from nature to depict Sister Maureen's inability to escape her memories.

Sister Maureen "cannot shut the singing out" as the "air hums" and "the wings of bees beg for entrance." ${ }^{87}$ Once again, Williams depicts the line of the poem through timbre. The flutist simultaneously sings and plays quietly (figure 6), which creates a buzzing sound that represents the humming air.

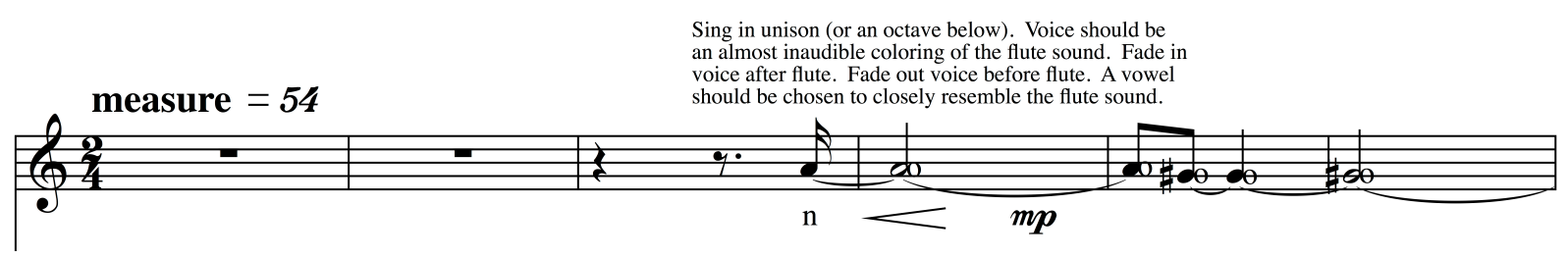

Figure 6

\footnotetext{
${ }_{85}^{85}$ Williams, interview by author, 24 January 2014.

${ }_{87}^{86}$ Derricotte, Captivity, 41.

${ }^{87}$ Ibid.
} 
As seen in figure 7, the piano provides most of the musical content in this movement, and the juxtaposition of $7 / 8$ meter in the right hand and $5 / 8$ in the left hand produces, in the composer's words, a "free element of nature where things happen rhythmically that sound regular but they are also very unpredictable. If you hear crickets chirping it can feel regular but it turns into crazy polyrhythms" when notated. ${ }^{88}$ Williams goes on to say the following:

After the second movement where the flute and piano parts are so coordinated, and the sounds are so connected, I wanted a movement where the two instruments are two very independent creatures. The flute is more the air humming at night, and the buzzing sound is meant to be something otherworldly. The piano is more the clicking of the bees' wings. It's something that's found in nature. They are two very independent parts in terms of texture. ${ }^{89}$

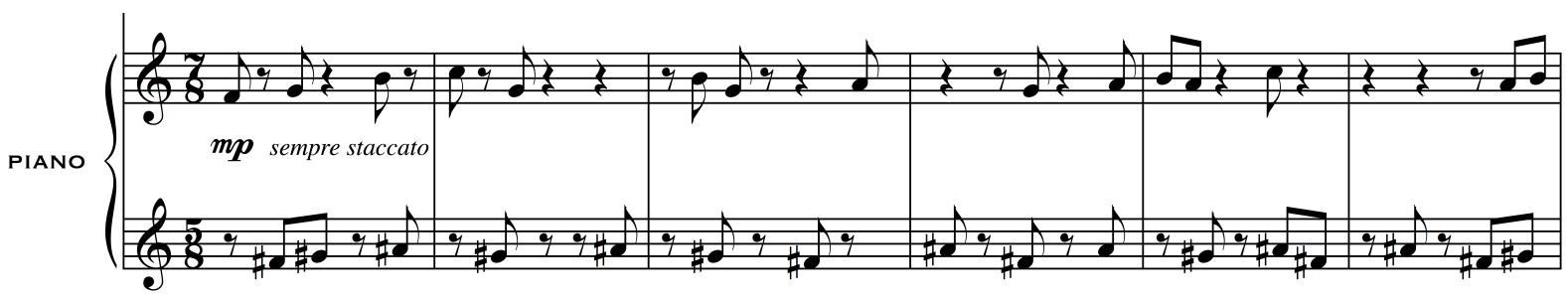

Figure 7

$I V$. "In the margins you roam free... ${ }^{90}$ The old neon flickers and hums... 91 ",

The fourth movement of First Lines is the only one to combine texts from two different poems. The lines "In the margins you roam free"92 and "The old neon flickers and hums"93 are both found in Chin's collection Rhapsody in Yellow. Williams uses each instrument to depict a different line.

${ }_{89}^{88}$ Williams, interview by author, 24 January 2014.

${ }^{89}$ Ibid.

${ }^{90}$ Chin, Rhapsody in Plain Yellow, 92.

${ }_{91}^{91}$ Chin, Rhapsody in Plain Yellow, 77.

${ }_{92}$ Chin, Rhapsody in Plain Yellow, 92.

${ }^{93}$ Chin, Rhapsody in Plain Yellow, 77. 
The piano, with its unpredictable timbre changes, portrays the neon flickering as "an idea of a sound, that it's an object but has other sounds associated with it." 94 The piano's bass line was composed first, ${ }^{95}$ with the directive to "dampen strings near pins with fingers [and] move positions on string freely on each new attack to activate different timbres, ${ }^{, 96}$ musically depicting the erratic imagery of the poem (figure 8).

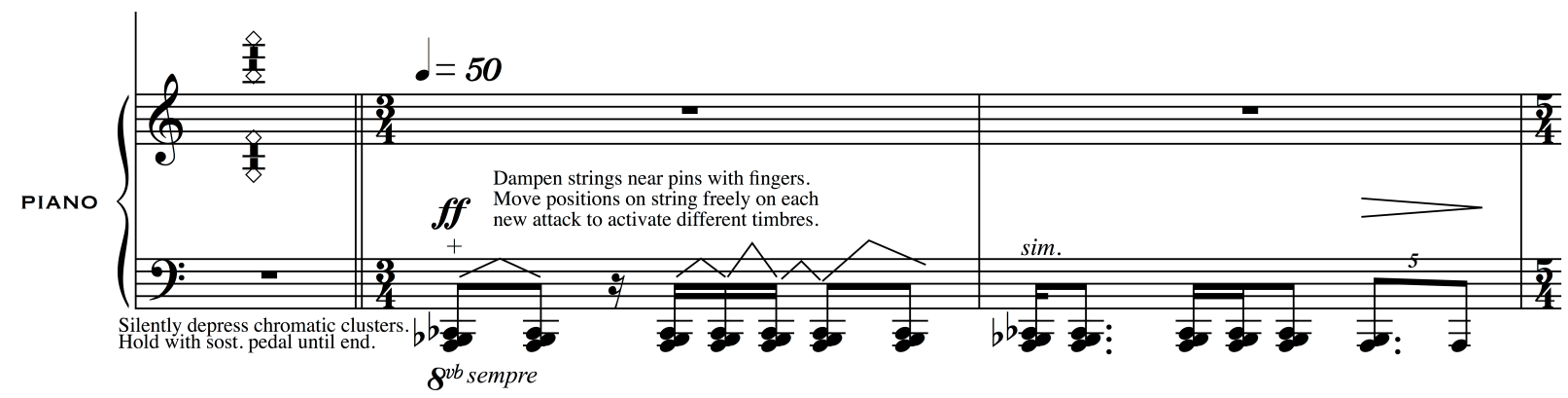

Figure 8

The flute line, on the other hand, represents "In the margins you roam free," from the piano in register, rhythm, and timbre (figure 9).

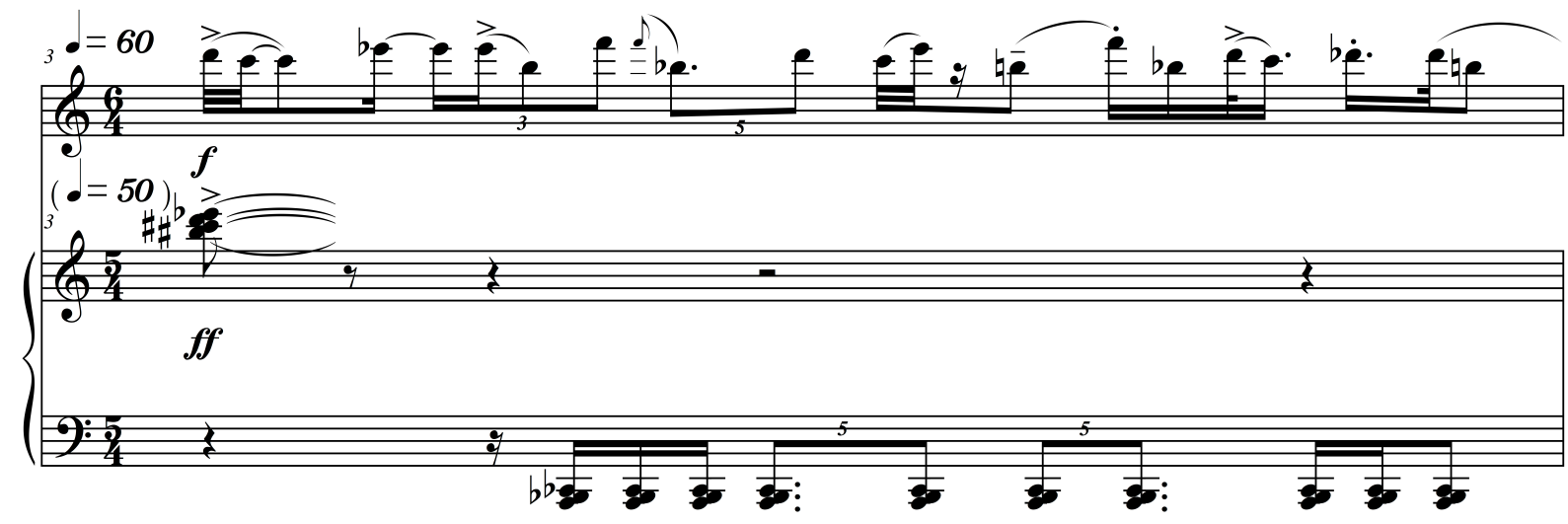

Figure 9

\footnotetext{
${ }_{95}^{94}$ Williams, interview by author, 24 January 2014.

${ }^{95}$ Ibid.

${ }^{96}$ Williams, First Lines, 6.

${ }^{97}$ Chin, Rhapsody in Plain Yellow, 92.
} 
Although the two instruments function independently in this movement, they align at key moments, as in measure 5 (the flute's beat 2 in measure 5 , figure 10). This provides both "connection points and flexibility" 98 that musically supports the combination of these two texts, as well as the imagery inherent in each of the two opening lines.

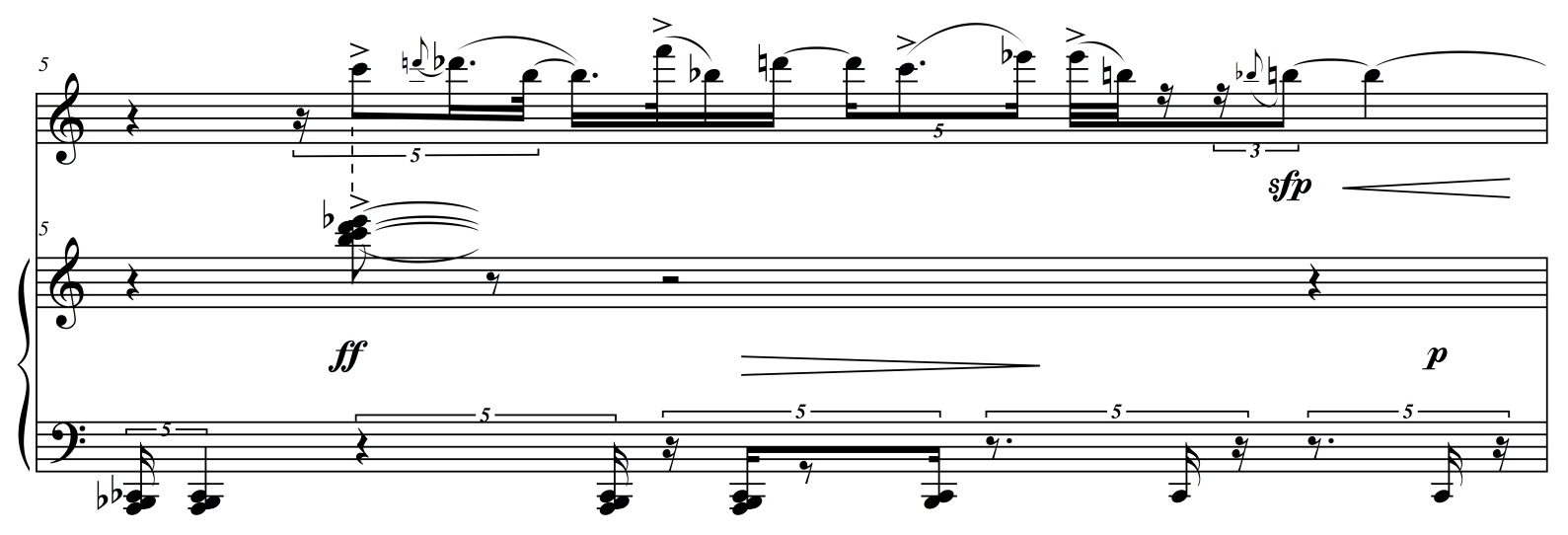

Figure 10

V. "That half is almost gone, / the Chinese half...",99

Movement V sees the flute and piano working closely together again, despite their registral separation. Hocket is the basis of this coordination. In measures $1,3,5,6$, and 8 , the flute and piano work together to produce complex rhythmic gestures that often consist of quintuplets (figure 11). Rather than develop something that seemed to "work as something really short," 100 Williams "inserted something new as an ending gesture, "101 incorporating harmonics and whistle tones in the flute to create an ethereal, evaporative sound in measures 10 and 11 (see

\footnotetext{
${ }^{98}$ Williams, interview by author, 24 January 2014.

${ }^{99}$ Chin, Rhapsody in Plain Yellow, 17.

${ }^{100}$ Williams, interview by author, 24 January 2014.

101 Ibid.
} 
figure 11). There is a nod to the pentatonic scale in measures 2 and 4 , alluding to the poet's heritage, but in a way that prevents Williams from being "too direct."102
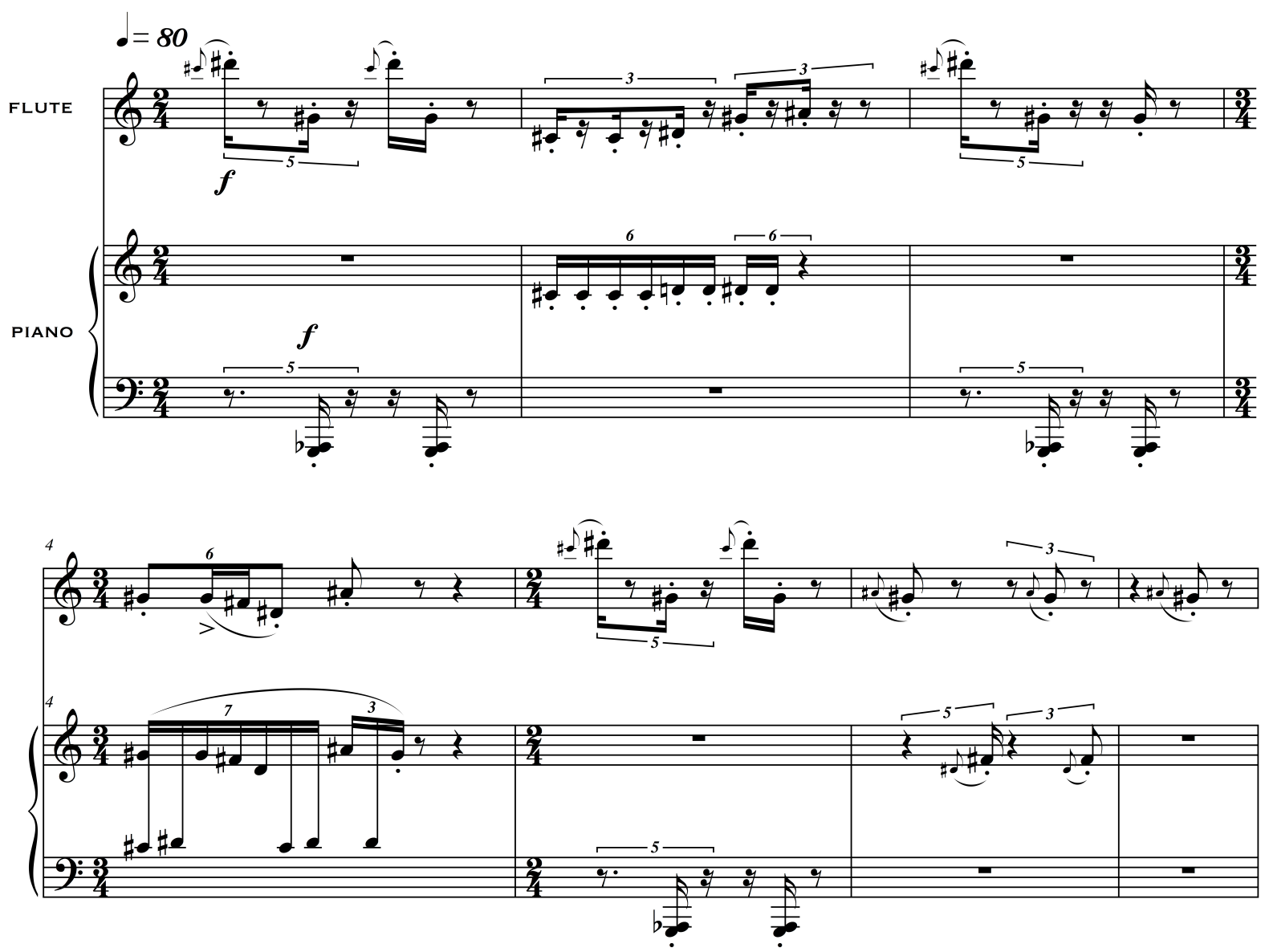

Figure 11 (continued on the next page)

${ }^{102}$ Williams, interview by author, 24 January 2014. 


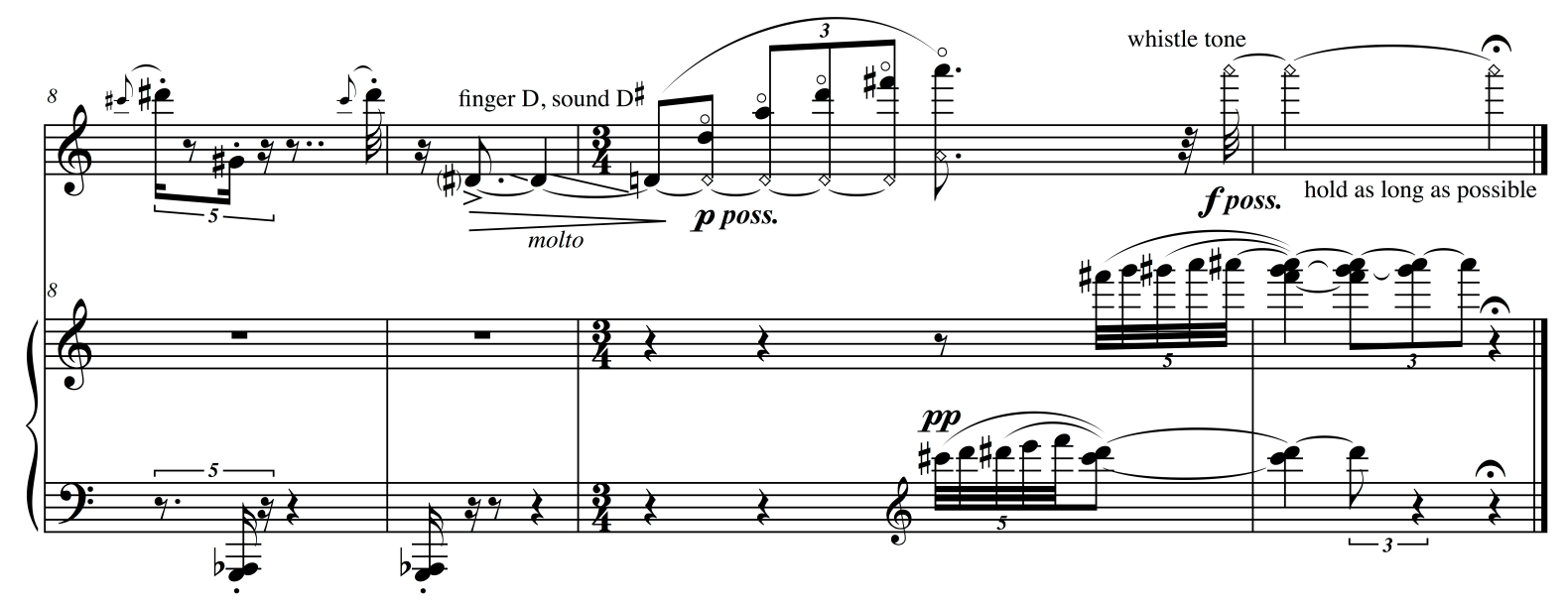

Figure 11 (continued)

To Goodman, this movement seems like a conversation, with the piano acting as an overbearing parent, while the flute continually backs away. ${ }^{103}$ She states, "By the end, the flute line is being completely lost while the piano keeps itself rooted in traditional techniques, and the flute goes farther afield and loses all traces of its traditional sound."104 This analysis fits with Chin's constant struggle to blend the duality of her Chinese and American selves, and reflects the fear that "That half is almost gone, the Chinese half..."

VI. "Shhh, my grandmother is sleeping...",106

According to Williams, Movement VI is the miniature that everyone seems to understand on first hearing: "I've done experiments with students where I give them the poem and play the music to see if they can coordinate them and they have quite a difficult time, but this one they

\footnotetext{
${ }^{103}$ Goodman, interview by author.

104 Ibid.

${ }_{105}$ Chin, Rhapsody in Plain Yellow, 17.

${ }^{106}$ Chin, Rhapsody in Plain Yellow, 41.
} 
almost always get." ${ }^{107}$ This movement of First Lines is the most "directly narrative,"108 as

Williams again uses timbre to depict an image, this time of an old woman sleeping in a hospital bed.

An initial fortissimo in measure 2, played by the both the flute and piano, impels the imperative to "Shhh"109 (figure 12).
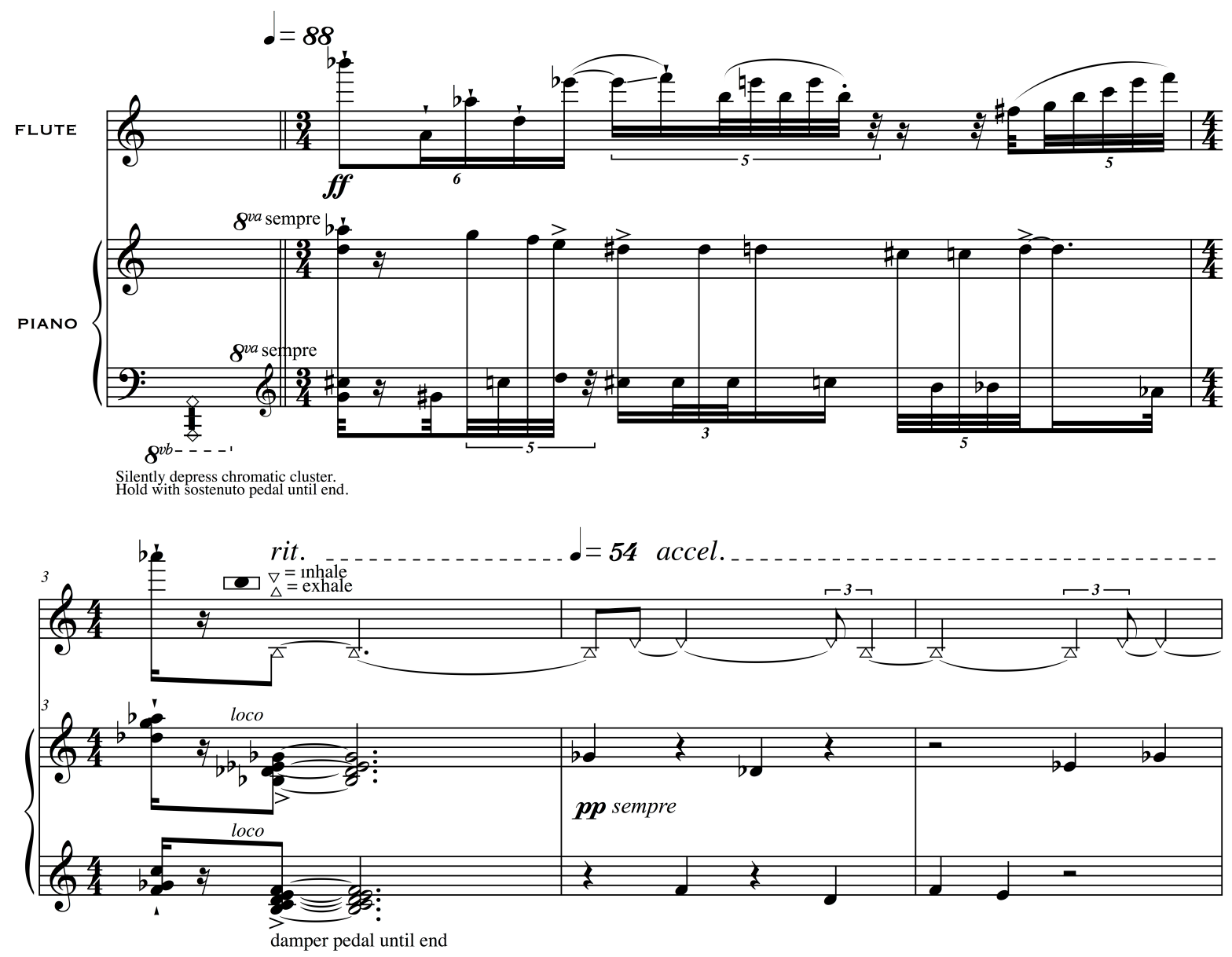

Figure 12

${ }^{107}$ Williams, interview by author, 24 January 2014.

${ }^{108}$ Ibid.

${ }^{109}$ Chin, Rhapsody in Plain Yellow, 41. 
Following the initial cacophony in measure 1, the flutist is asked to inhale and exhale with the entire embouchure hole covered, which produces not a tone so much as a sound reminiscent of someone sleeping (measure 3 in figure 12).

In measure 18 (figure 13), the flutist "stop[s] suddenly,"110 creating a moment of "apnea."111

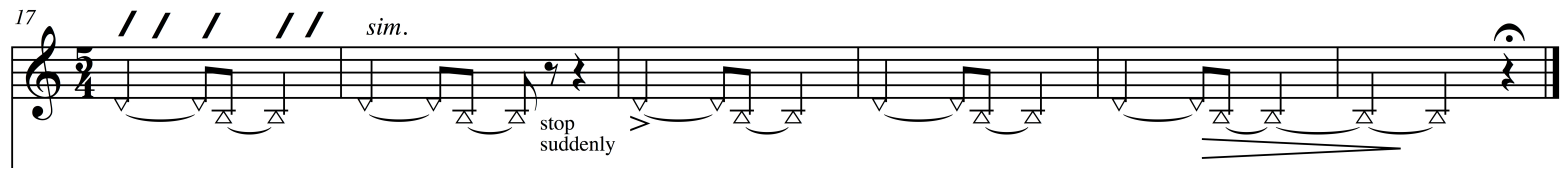

Figure 13

Throughout the movement, the piano plays quarter notes (see figure 12), but with tempo changes that allow for "another way of playing with rhythmic flexibility"112 This rhythmic flexibility represents the irregular breathing of someone who is very ill. Williams says that the "feeling of rubato, something that is stable, but fluid was what I was going for.""113

VII. "And sometimes, when the sun stands up / Right out of the ground...",114

Williams wanted to create a "coordinated, blended sound between the two instruments, so it's really one instrument" in the seventh movement of First Lines, as well as "something that would continue to rise." ${ }^{\prime 15}$ Williams uses variability in tempo and rhythm to evoke the image of sunrise. It is often our perception that the sun's motion changes in speed, first just peeking out from the horizon and then seeming to rush upwards to full daybreak. Although the piano and

\footnotetext{
${ }^{110}$ Williams, First Lines, 11.

${ }^{111}$ Williams, interview by author, 24 January 2014.

112 Ibid.

113 Ibid.

${ }_{115}^{114}$ Patricia Goedicke, Listen, Love (Danville, Barnwood, 1986), 33.

${ }^{115}$ Williams, interview by author, 24 January 2014.
} 
flute perform mostly in rhythmic unison, each measure contains irregular beat lengths and subdivisions, including 5:4, 7:4, and 4:3, which create ebb and flow throughout the movement. (See measures 1 and 2 in figure 14).

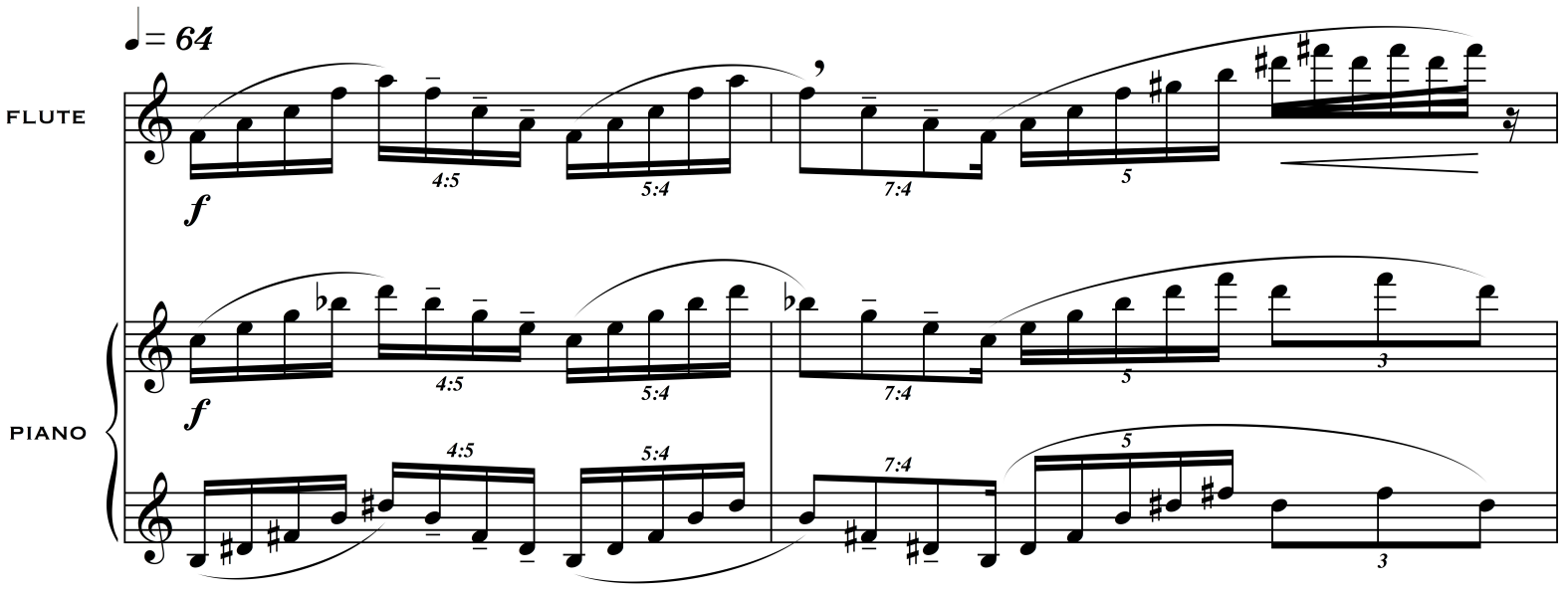

Figure 14

Although each measure contains three groups of notes, the absence of a time signature or a consistent subdivision keeps the overall pulse of this movement in flux. Additionally, every 3 measures, a subito tempo change occurs, requiring the instruments to abruptly move together at a quicker speed (see figure 15).

Williams begins Movement VII with the flute on F4 and the piano on B3 ${ }^{116}$ to make sure that the flute and piano sound as much like one instrument as possible (figure 14). This avoids the lowest flute pitches, which can possess an unfocused timbre and one that Williams felt would not match the piano in tone color. ${ }^{117}$ From that starting point, the two instruments perform

\footnotetext{
${ }^{116}$ The standard adopted by the Acoustical Society of America, where middle C is referred to as C4, is used throughout this document.

${ }^{117}$ Williams, interview by author, 24 January 2014.
} 
almost entirely in rhythmic unison until measure 7, matched in both register and rhythm. At measure 9, the flute and piano play in contrary motion for the final five measures of movement VII (figure 15).
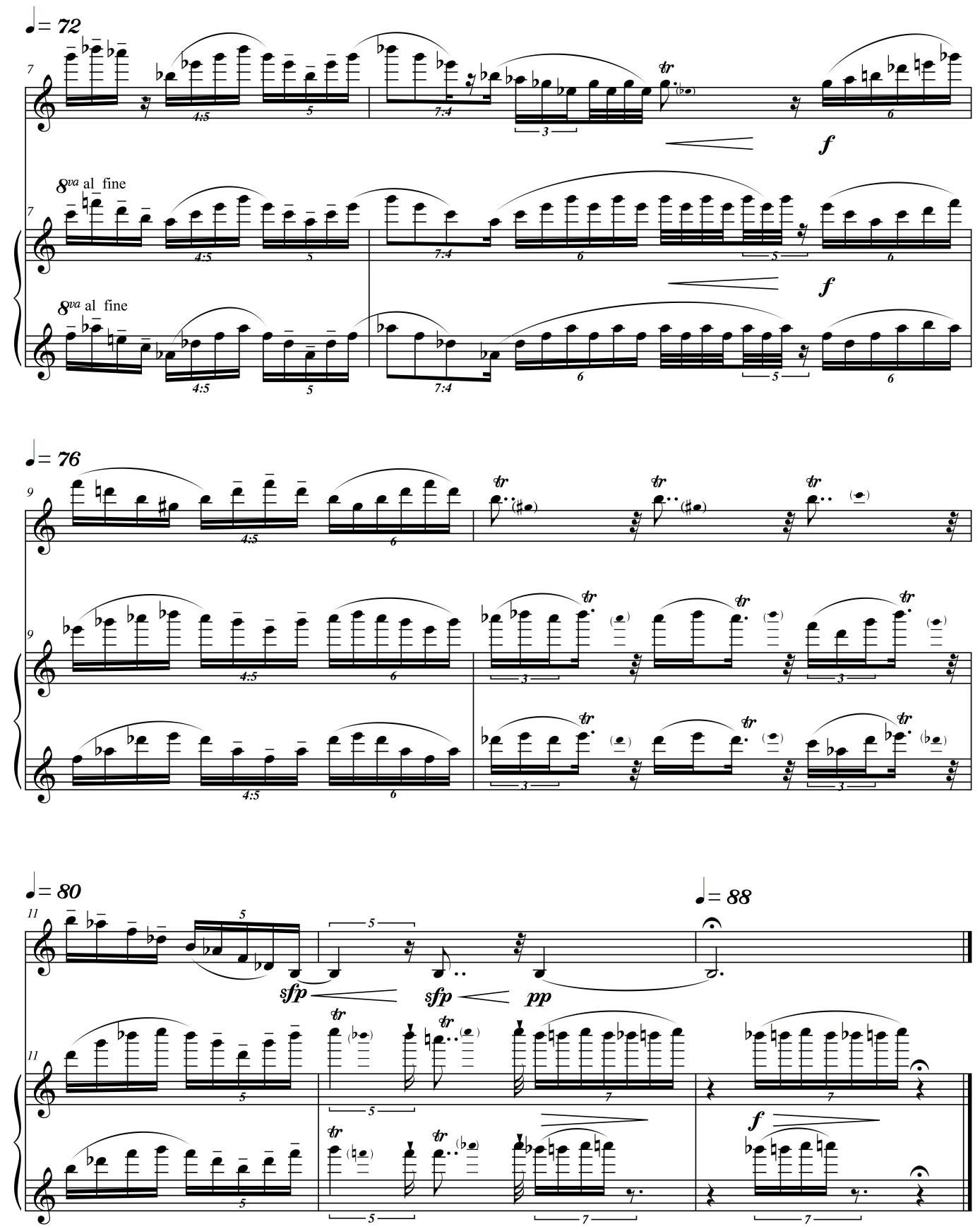

Figure 15 
The piano continues to rise and the flute begins a gradual descent, with the two instruments separated by three octaves by the final measure. The piano can continue to ascend much higher than the flute, and contrary motion is used here to deal with that practical compositional detail. ${ }^{118}$ Williams shared that, "something different or special happens at the end. That was a way for me to get out of the pieces, to get out of each one so that they feel complete."119

VIII. “Gestures made against snow: / The fling / And scatter of birdseed onto burned grass..." In contrast to the unity of the flute and piano in the previous movement, movement VIII functions primarily as a piano solo with a brief interjection by the flute in measures 11 and 12 that Williams describes as "almost comical [and] joking""121 (figure 16).

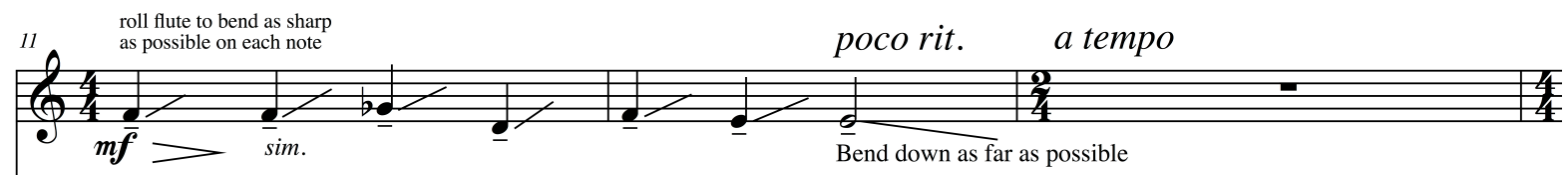

Figure 16

Recurring rhythmic motives in the piano part and extreme changes in register from one sixteenth-note to the next reflect Goedicke's "fling / And scatter of birdseed"122 (figure 17). Williams again writes with incredible rhythmic detail, subtly changing a rhythmic figure with a sixteenth-note subdivision in one beat to one subdivided into a triplet or quintuplet figure in the next. This can be observed in measure 2 (figure 17). This specificity of rhythmic complexity is

\footnotetext{
${ }^{118}$ Williams, interview by author, 24 January 2014.

119 Ibid.

${ }^{120}$ Goedicke, Listen, Love, 38.

${ }^{121}$ Williams, interview by author, 24 January 2014.

${ }^{122}$ Goedicke, Listen, Love, 38.
} 
what creates the illusion of randomness, and reflecting those gestures "made against the snow.",123
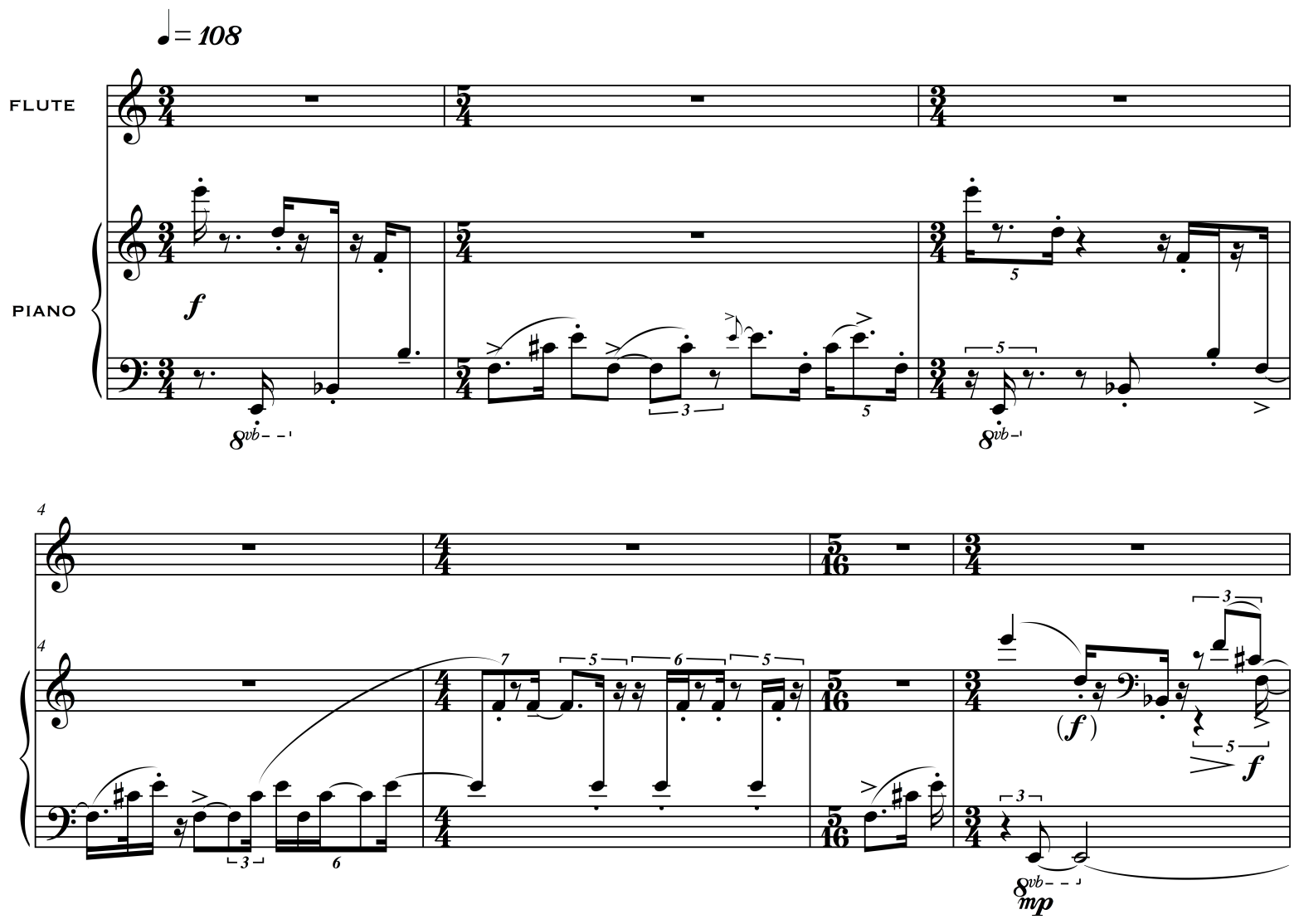

Figure 17

IX. "First it is only the sense of sunlight / Creeping up over the dunes...",124

Movement IX serves as a contrast to the preceding movement in two ways: its character is more quiet and tranquil, and the relationship between the two instruments inverts, centering on the flute, while the piano provides accompaniment. In the flute part, series of trills and tremolos centered on E4 create a mood or atmosphere ${ }^{125}$ that is reflective and still (figure 18).

${ }^{123}$ Goedicke, Listen, Love, 38.

${ }_{124}$ Goedicke, Listen, Love, 51.

${ }^{125}$ Williams, interview by author, 24 January 2014. 


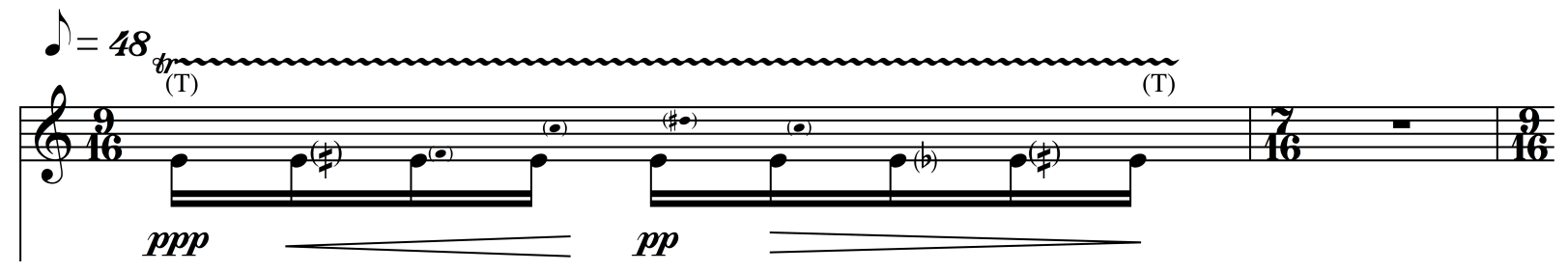

Figure 18

These trills do not serve to propel the motion forward, and have a very limited dynamic range, expanding only from pianississimo to pianissimo. This brings to mind "the sense of sunlight / Creeping up over the dunes." 126 The sunrise finally occurs in measure 14, when the flutist is asked to rise fortissimo and "overblow"127 the trills (figure 19).

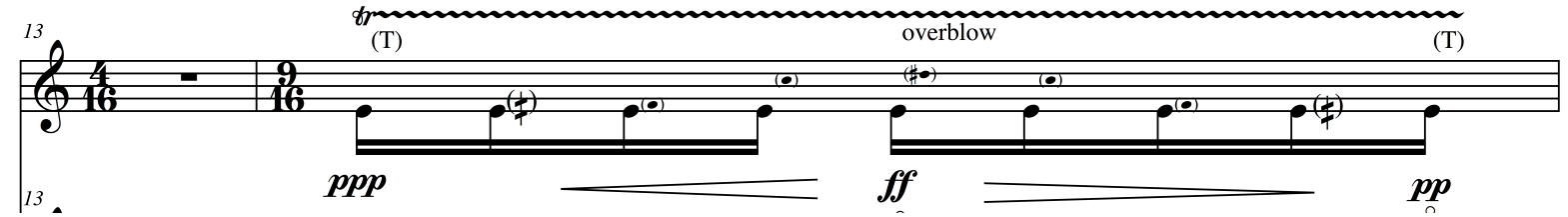

Figure 19

According to Williams, “after that moment it can't just go back to what it was. So it starts to dissipate after that point."128

Throughout the movement, the piano remains "almost inaudible"129 and quietly supports the flute. In measure 11, Williams instructs the pianist to "slide [the] finger toward [the] damper so each note has a change in timbre. Do not move so far as to sound the next harmonic"130 (figure 20).

\footnotetext{
${ }^{126}$ Goedicke, Listen, Love, 51.

${ }^{127}$ Williams, First Lines, 17.

${ }^{128}$ Williams, interview by author, 24 January 2014.

${ }^{129}$ Williams, First Lines, 16.

${ }^{130}$ Williams, First Lines, 17.
} 


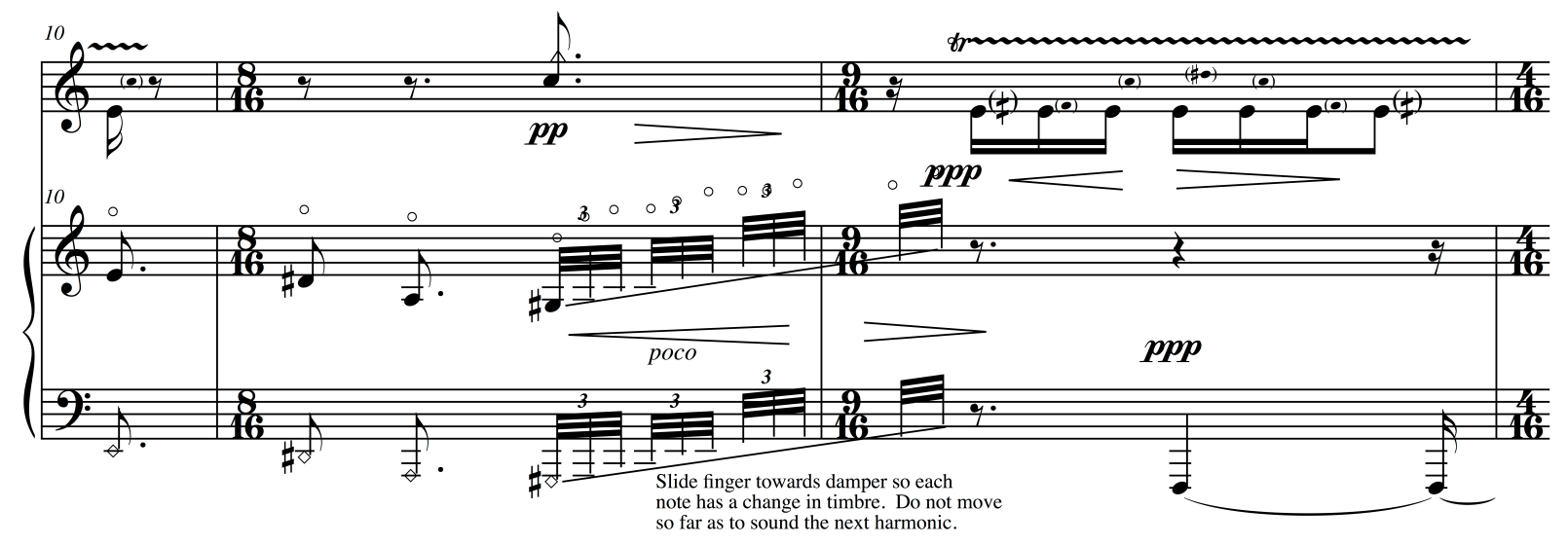

Figure 20

This ascending figure, with its special, muted sound effect, coordinates with the only non-trill idea found in the flute part, a breathy $\mathrm{C} 5$. This $\mathrm{C} 5$ is only heard once more, in the final measure of the movement. In an effort to keep each movement to an appropriate miniature proportion, "the piano is intentionally quite simple and the flute does basically one thing, so it's another example of very limited materials"131 used throughout the composition.

X. "Is that only the windows creaking, Maria, / the wounded panes in them trembling?...",132

Described by the composer as a "counterpart" or "bookend" 133 to Movement II, Movement $\mathrm{X}$ of First Lines provides another opportunity to bring the flute and piano together as a unit after their contrasting solo roles in movements VIII and IX. In order to create the sense of "windows creaking," ${ }^{, 134}$ rhythmic coordination between the two instruments is paramount. ${ }^{135} \mathrm{In}$ some instances, including beats 1 and 2 of measure 1 and the first gesture in measure 2 , the flute

${ }^{131}$ Williams, interview by author, 24 January 2014.

132 Olga Sedakova, The Silk of Time: Bilingual Selected Poems (Keele, Keele University Press, 1995), 23.

${ }^{133}$ Williams, interview by author, 24 January 2014.

${ }_{135}^{134}$ Sedakova, The Silk of Time, 23.

${ }^{135}$ Williams, interview by author, 24 January 2014. 
and piano begin on a unison pitch before the flute continues with the gesture. The piano provides additional timbral interest at the beginning of each gestural comment (figure 21).
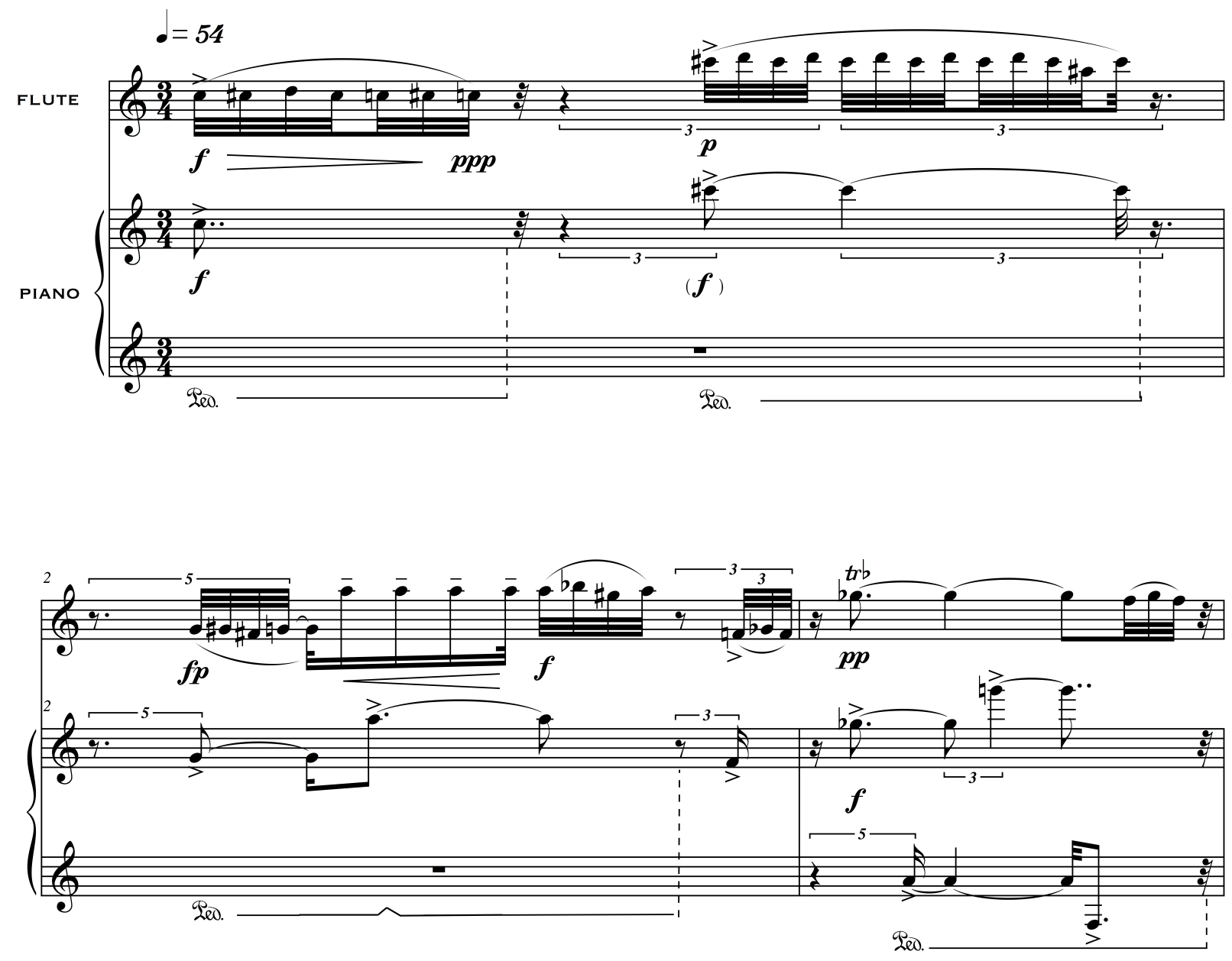

Figure 21 
In other places, like measures 3 and 5, the flute and piano diverge before realigning in the subsequent measures (figure 22).
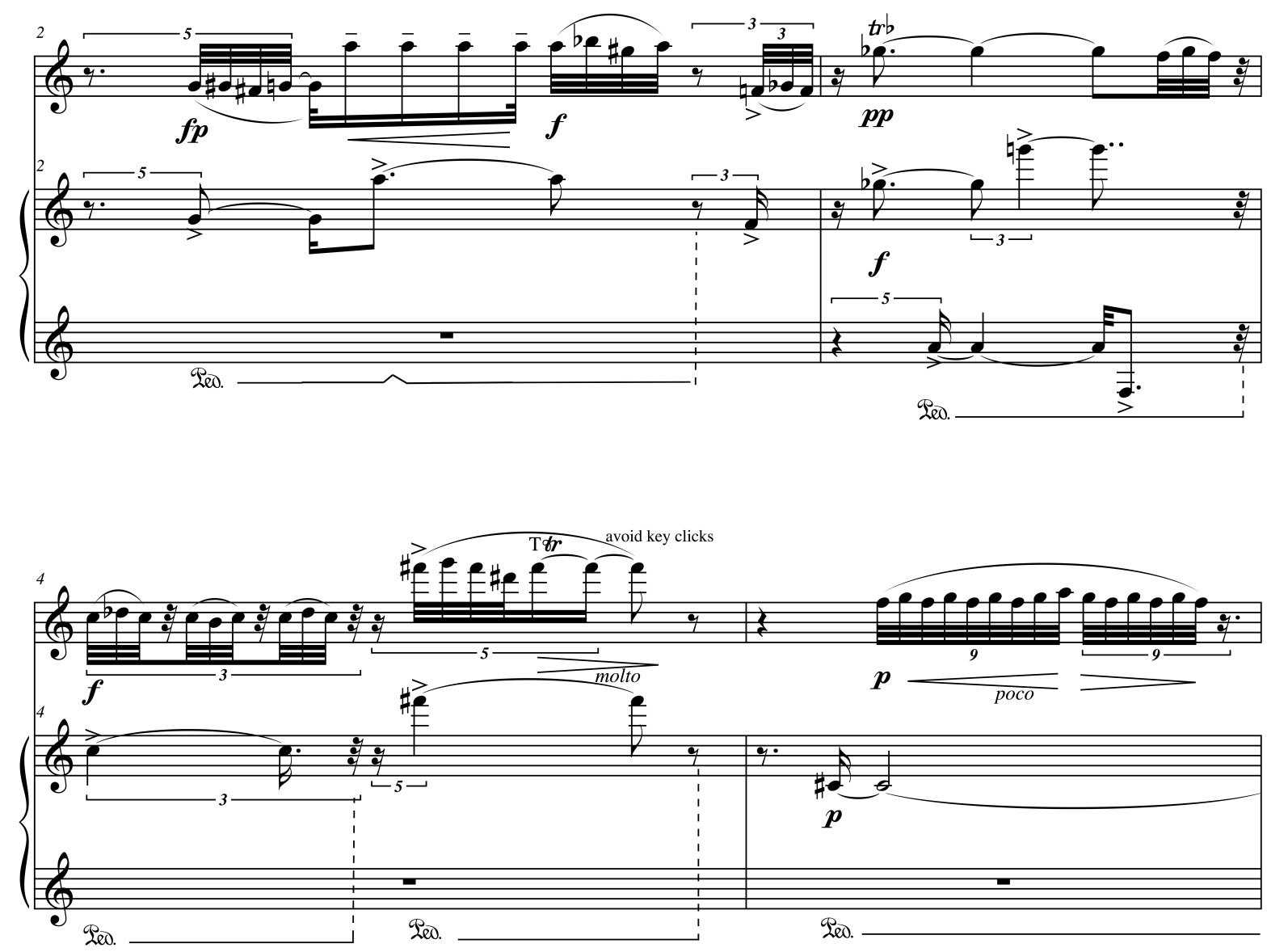

Figure 22

Williams created these rhythmic details because the poem "suggested a certain kind of rhythm, a quick-moving, trembling sound that had its own rhythmic profile suggested by the poem." ${ }^{136}$ Chromatic figures, timbral trills, and alternate fingerings communicate the sense of

\footnotetext{
${ }^{136}$ Williams, interview by author, 24 January 2014.
} 
"trembling"137 in the flute part, and the sound of the keys moving on the instrument "imitate the rattling of the glass in the wood"138 (figure 23).

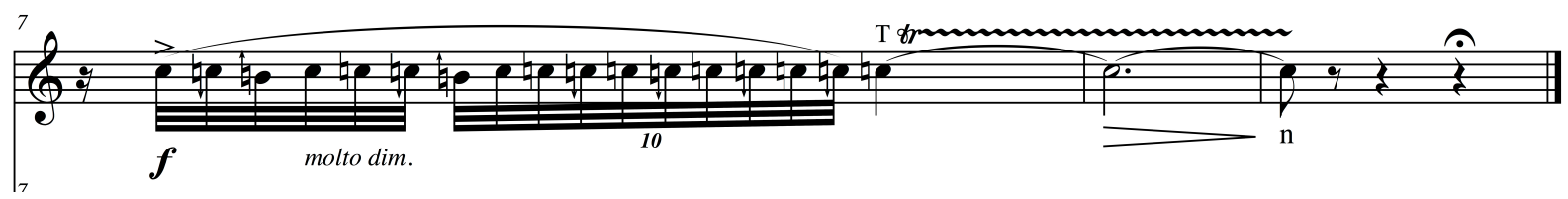

Figure 23

XI. "I was surprised by / how calm the waters were...",139

According to Williams, what appealed to her about this poem was "not just that the water is calm, but that I was surprised by it." ${ }^{140}$ Therefore, "there has to be a sense of wonder""141 in the performance as well.

The flute and piano play two characters in this final movement. The piano is the water that "is so consistent and flowing," 142 represented musically by constant eighth notes that ascend and descend to form calm waves (figure 24).

${ }_{138}^{137}$ Sedakova, The Silk of Time, 23.

${ }^{138}$ Goodman, interview by author.

${ }_{139}^{139}$ Sedakova, The Silk of Time, 73.

${ }^{140}$ Williams, interview by author, 24 January 2014.

${ }^{141}$ Ibid.

${ }^{142}$ Ibid. 


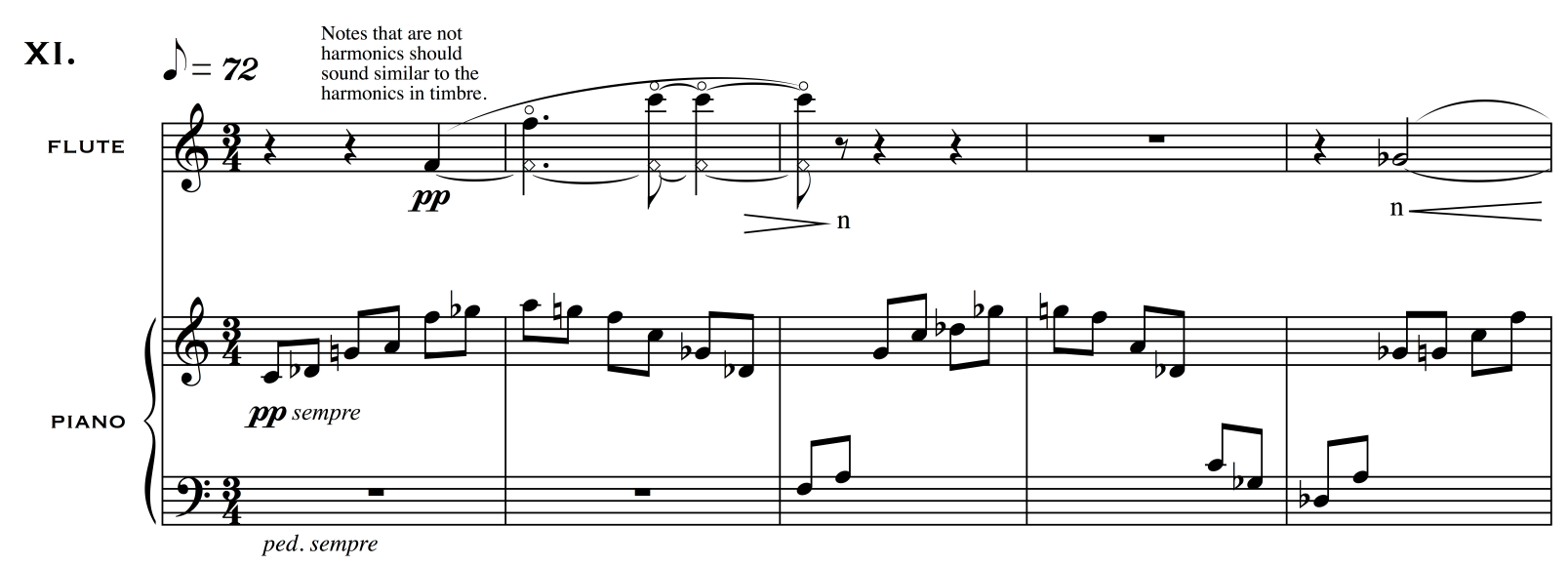

Figure 24

Each occurrence of this figure is fairly limited in range, and the slow tempo (eighth note equals 72) keeps the motion placid throughout.

Meanwhile, the flute is "a little bit more temperamental, or moodier" and provides contrast to the piano by being "improvisational or rhapsodic. ${ }^{143}$ This is demonstrated primarily by the accelerando figures in measures 7, 8, 13, 14, 20,21, and 22 (see measures 7 and 8 in figure 25), where the flutist is directed to use a very breathy sound to "overblow," 144 creating a temporary disturbance in the overall sense of calm in the movement.

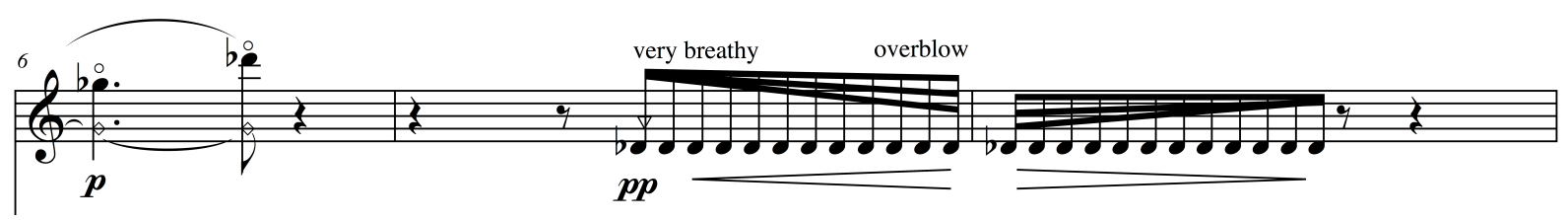

Figure 25

${ }^{143}$ Williams, interview by author, 24 January 2014.

${ }^{144}$ Williams, First Lines, 20. 
Conversely, the use of harmonic fingerings in the flute part support the sense of tranquility and quiet movement established by the piano (figure 24). 


\section{Chapter 4: Performance Suggestions for First Lines}

The following chart will be useful to flutists studying First Lines as they familiarize themselves with the techniques used throughout the piece.

Table 1: Extended Techniques for Flute in First Lines

\begin{tabular}{|c|c|c|}
\hline Symbol & Meaning & Explanation \\
\hline$[\Omega]$ & $\begin{array}{l}\text { Mouthpiece } \\
\text { Covered }\end{array}$ & $\begin{array}{l}\text { Roll in the flute and completely cover the embouchure hole } \\
\text { with the mouth. Blow air directly into the flute. }{ }^{145}\end{array}$ \\
\hline$X$ & Key Click & $\begin{array}{l}\text { Key clicks involve slapping one or more keys on the flute. }{ }^{146} \\
\text { Tone may or may not be simultaneously produced. } \\
\text { Typically, slapping the G key is the preferred method. }\end{array}$ \\
\hline Z & $\begin{array}{l}\text { Pizzicato } \\
\text { Tonguing }\end{array}$ & $\begin{array}{l}\text { According to Robin Mason Horne, pizzicato tonguing is "a } \\
\text { sort of percussive 'pop' that is done using the tongue and the } \\
\text { lips. Make your lips very firm, stick your tongue out through } \\
\text { them and insert into the embouchure hole on the headjoint, } \\
\text { then pull it back in rapidly. As the air rushes in to the mouth } \\
\text { and you get a little popping sound."147 }\end{array}$ \\
\hline$\Phi$ & Breathy & $\begin{array}{l}\text { Create a sound that is part tone and part air. Raising the } \\
\text { airstream using the lips and lifting the chin results in a } \\
\text { breathy, unfocused sound. }{ }^{148}\end{array}$ \\
\hline$\frac{1}{\nabla}$ & Breath Only & $\begin{array}{l}\text { When playing, raise the airstream to an extreme that results } \\
\text { in an airy sound without any tone. The hiss of the air hitting } \\
\text { the opposite wall of the embouchure hole will produce the } \\
\text { desired effect. }{ }^{149}\end{array}$ \\
\hline$\Delta$ & Exhale & $\begin{array}{l}\text { With the mouthpiece completely covered with the mouth, } \\
\text { the flutist should exhale into the flute. }\end{array}$ \\
\hline$\nabla$ & Inhale & $\begin{array}{l}\text { With the mouthpiece completely covered with the mouth, } \\
\text { the flutist should inhale. }\end{array}$ \\
\hline
\end{tabular}

${ }^{145}$ Williams, interview by author, 24 January 2014.

${ }^{146}$ Robert Dick, The Other Flute, (St. Louis, Multiple Breath, 1989) 136.

${ }^{147}$ Robin Mason Horn, "Extended Techniques Resource Page." Larry Krantz Flute Pages. http://www.larrykrantz.com/et/et.htm\#Instructional [accessed November 6, 2014]. ${ }_{148}$ Andrea Ceccomori, interview by author, phone, Morgantown, WV 3 March 2010.

149 Williams, interview by author, 24 January 2014. 


\begin{tabular}{|c|c|c|}
\hline do & $\begin{array}{l}\text { Singing and } \\
\text { Playing } \\
\text { Simultaneously }\end{array}$ & $\begin{array}{l}\text { This technique involves using the vocal chords to sing while } \\
\text { playing notes on the flute. In First Lines, singing occurs in } \\
\text { unison with the flute pitch or at the octave. Dick notes that } \\
\text { "singing and playing simultaneously restricts the dynamic of } \\
\text { the played pitch to an approximate range of mp-f.",I50 }\end{array}$ \\
\hline $\mathrm{T}$ & $\begin{array}{l}\text { Timbral } \\
\text { Modification }\end{array}$ & $\begin{array}{l}\text { An alternate fingering may be used to alter the timbre of a } \\
\text { particular pitch. Fingerings are indicated in the piece }\end{array}$ \\
\hline$T_{\not b r}$ & Timbral Trill & $\begin{array}{l}\text { A timbral trill alternates between two different fingerings of } \\
\text { the same pitch, producing a very fast timbral modification. } \\
\text { Fingerings are indicated in the piece. }\end{array}$ \\
\hline$\#$ औb & Slightly Sharp & $\begin{array}{l}\text { Raising the angle of the airstream and lifting the chin will } \\
\text { slightly sharpen the pitch of the indicated note. }\end{array}$ \\
\hline 乌 & Slightly Flat & $\begin{array}{l}\text { Lowering both the chin and the angle of the air stream will } \\
\text { result in a slightly flat pitch. }\end{array}$ \\
\hline$\ddagger$ & $\begin{array}{l}\text { Quarter-tone } \\
\text { Sharp }\end{array}$ & $\begin{array}{l}\text { In order to make a pitch sound a quarter-tone sharp, special } \\
\text { fingerings can be used to raise the pitch. This can be done in } \\
\text { conjunction with raising the angle of the air by rolling out } \\
\text { the headjoint. Alternate fingerings can be found in Robert } \\
\text { Dick's The Other Flute or James Pellerite's Modern Guide } \\
\text { to Fingerings on the Flute. }\end{array}$ \\
\hline l & $\begin{array}{l}\text { Quarter-tone } \\
\text { Flat }\end{array}$ & $\begin{array}{l}\text { In order to make a pitch sound a quarter-tone flat, special } \\
\text { fingerings can be used to lower the pitch. This can be done } \\
\text { by directing the air column down or by rolling in the } \\
\text { headjoint. Alternate fingerings can be found in Robert } \\
\text { Dick's The Other Flute or James Pellerite's Modern Guide } \\
\text { to Fingerings on the Flute. }\end{array}$ \\
\hline 些 & $\begin{array}{l}\text { Three Quarter- } \\
\text { Tones Sharp }\end{array}$ & $\begin{array}{l}\text { In order to make a pitch sound a three-quarters-tone sharp, } \\
\text { special fingerings can be used to raise the pitch. This can be } \\
\text { done by directing the air column down or by rolling in the } \\
\text { headjoint. }\end{array}$ \\
\hline$\rightarrow$ & $\begin{array}{l}\text { A Gradual } \\
\text { Change }\end{array}$ & $\begin{array}{l}\text { When moving from one timbral effect to another, the } \\
\text { resulting sound should happen by degrees, not immediately. }\end{array}$ \\
\hline
\end{tabular}

${ }^{150}$ Dick, The Other Flute, 143. 


\begin{tabular}{|l|l|l|}
\hline whistle tone & Harmonics & $\begin{array}{l}\text { Harmonics are produced when a fundamental note is } \\
\text { fingered, and the flutist changes the direction of the air to } \\
\text { produce one of the pitches in that fundamental's harmonic } \\
\text { series. In First Lines, Williams has indicated all of the } \\
\text { fundamental fingerings. }\end{array}$ \\
\hline
\end{tabular}

Compositions that include extended techniques for flute are no longer uncommon, thanks to the work of several prominent flutists, including Severino Gazzelloni, Robert Dick, Robert Aitken, and Ian Clark. Many flute pedagogues utilize the exercises found in Robert Dick's Tone Development Through Extended Techniques to help their students use non-traditional methods to improve their flute tone. It is likely that an advanced or professional musician performing First Lines will have encountered a composition using at least some of the extended techniques included in the piece.

One of the challenges of performing extended techniques is interpreting exactly which effect the composer intends, and to what end. This is because each composer may have a slightly different method of notating these methods into their musical works. With an older composition, the performer can consult one or more recordings, but fewer extant examples of new music exist, and may not be available for reference. It is therefore helpful to gain perspective from musicians who have already played First Lines for practical insights on their approach to learning and performing the piece.

${ }^{151}$ Dick, The Other Flute, 140. 
For the purposes of this document, flutists Lindsey Goodman, Alberto Almarza, and Andrea Ceccomori have been consulted for their performance suggestions. The composer has also provided suggestions for performing First Lines. Additionally, Williams, a pianist, also shared recommendations for approaching the non-traditional requirements found in the piano part. Biographies and other pertinent information concerning the consulting flutists can be found in Appendix III.

Many of the techniques used throughout First Lines produce timbral effects, as Williams creates a specific soundscape to coordinate with each poetic text. Because Williams studied with Robert Dick and worked closely with Lindsey Goodman as First Lines was being composed, great sensitivity has been taken to insure that all required techniques are practical and performerfriendly. Williams used Robert Dick's The Other Flute to guide her technical choices, and performers may refer to that book to supplement the suggestions found in this chapter.

As in any piece of chamber music, coordination within the ensemble is paramount, especially in a work that is as rhythmically taxing as First Lines. Eye contact is necessary to effectively coordinate the entrances between the flute and piano throughout the piece. Williams suggests removing the music rack on the piano and placing it at an angle as to achieve better eye contact with the flutist, while allowing space for the pianist to work inside the piano when the score indicates. ${ }^{152}$ The flutist might consider standing deeply in the crook of the piano, facing slightly to the right to initiate eye contact. ${ }^{153}$ Another option is standing to the immediate right of the pianist, in alignment with the piano bench. ${ }^{154}$

\footnotetext{
${ }^{152}$ Williams, interview by author, 24 January 2014.

153 Goodman, interview by author.

${ }^{154}$ Alberto Almarza, interview by author, in person, Pittsburgh, PA 10 October 2010.
} 
When Williams originally conceived the idea for First Lines, she intended for the movements to be performed in any order, and suggested that they might be broken up into a shorter performance of two to three movements. However, after hearing the work performed, her preference is for the movements to be performed in the order in which they appear, although she defers to the discretion of the musicians. ${ }^{155}$

I. "I sit in front of him / and look him in the eye...",156

The opening movement of First Lines is the most complicated in its use of extended techniques in the flute part. Williams asks the flutist to alter the tone quality from more-to-less focused, and incorporates timbral and quarter-tone fingerings, key clicks, and pitch bends. There is much to coordinate in this movement, which is only nine measures in length. Williams recommends careful observation of the tempo marking (quarter note equals 76 beats per minute) so that the all effects will be audible and demonstrated effectively. ${ }^{157}$ If the performers rush, the audience can miss some of the many details.

In measures 1 and 2, three similar statements require the flutist to "gradually add breath and go sharp" ${ }^{158}$ (figure 26).

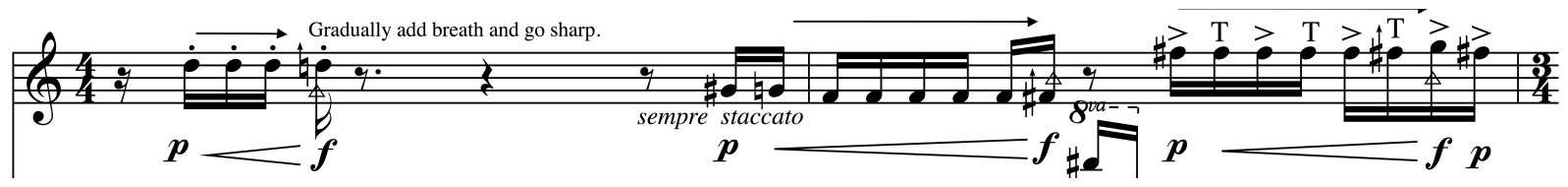

Figure 26

\footnotetext{
${ }^{155}$ Williams, interview by author, 24 January 2014.

${ }^{156}$ Derricotte, Captivity, 58.

${ }_{158}^{157}$ Williams, interview by author, 24 January 2014.

${ }^{158}$ Williams, First Lines, 2.
} 
To navigate these figures, which include dramatic crescendi from piano to forte, one can begin by practicing the addition of breath and the pitch change separately. ${ }^{159}$ Gradually raising the airstream towards the ceiling will change a focused tone to one that is breathy, ${ }^{160}$ and the aperture between the lips can also be made larger to make the sound more diffuse. ${ }^{161}$ Because the added breath takes place first over just one beat, and then over two, the change should happen at varying speeds to coordinate with the length of each respective gesture. ${ }^{162}$

Next, the pitch fluctuation and dynamics can be practiced with traditional tone before combining all of the elements required for the effect. ${ }^{163}$ To further exaggerate the change in pitch, Almarza suggests sliding the fingers to uncover the key holes on the flute. Slide the right hand ring finger on the D5 in measure 1, and the right hand index finger on the F4 in measure 2 (figure 26). ${ }^{164} \mathrm{~A}$ similar sliding technique can be used in measure 4, moving the right hand ring finger again on beats 2 and 3 (figure 27).

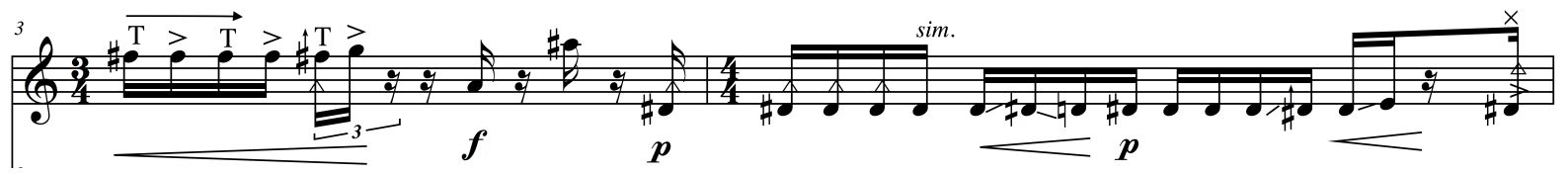

Figure 27

Sliding the right hand ring finger to uncover the key hole should be sufficient to move from D4 to $\mathrm{D} \$ 4$ on beat 2 , as well as the pitch bend from $\mathrm{D} \# 4$ to $\mathrm{D} \# 4$ on beat $3 .{ }^{165}$ To arrive at the $\mathrm{E} 4$ on beat 4 , the right hand ring finger can be completely removed from the key ring. ${ }^{166}$ For the

\footnotetext{
${ }^{159}$ Goodman, interview by author.

${ }^{160}$ Almarza, interview by author.

161 Goodman, interview by author.

${ }_{162}^{16}$ Ceccomori, interview by author.

163 Goodman, interview by author.

${ }_{165}^{164}$ Almarza, interview by author.

${ }^{165}$ Ibid.

${ }^{166}$ Ibid.
} 
final slide, on beat 4 of measure 5 (see figure 28), keep the C\# key down, while sliding the right hand ring finger first off of the key hole, and they release the key ring as well. ${ }^{167}$

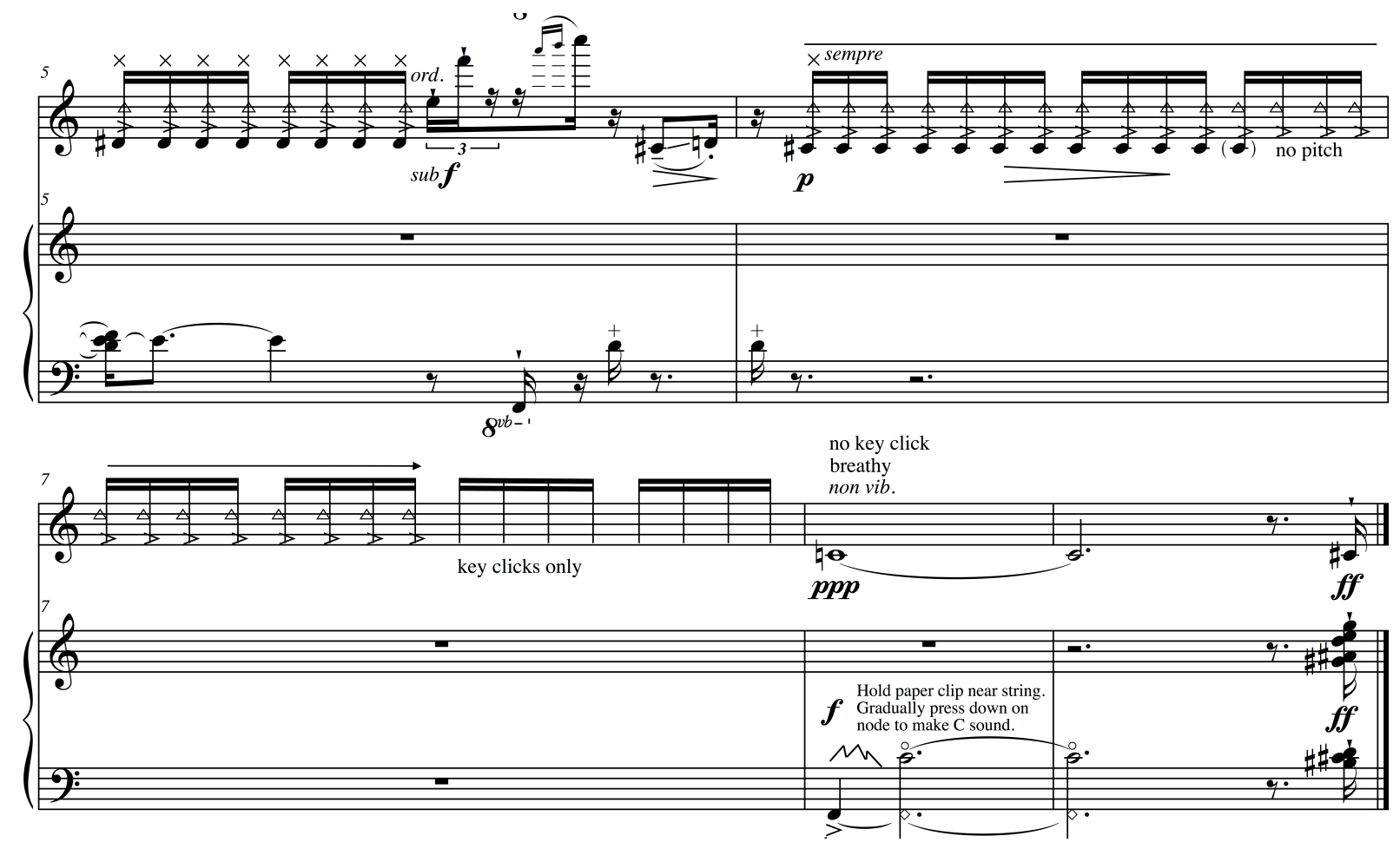

Figure 28

In measures 5, 6, and 7 (figure 28), Williams utilizes key clicks, and the left hand ring finger (or G-key) should be used as the striker key. ${ }^{168}$ The number of repeated key clicks creates a challenge, as it can be difficult to repeatedly perform them without producing grace notes between each written note. To avoid this, Goodman recommends keeping the sixteenth-note clicks as staccato as possible to create silence between the notes to obscure any untidiness in the technique. ${ }^{169}$

\footnotetext{
${ }^{167}$ Ibid.

${ }_{168}$ Ceccomori, interview by author.

${ }^{169}$ Goodman, interview by author.
} 
For the last two measures (figure 28), eye contact will help the flute and piano align, and the flutist can again raise the airstream and use a larger-than-normal lip aperture ${ }^{170}$ to create the "breathy" $\mathrm{C} 4$. Avoid breathing on the dotted-eighth rest before the final note to be perfectly in time with the pianist. ${ }^{172}$ It is also recommended that the pianist cue and begin Movement I to eliminate any awkwardness that might be caused from the flute's entrance on the second sixteenth-note of measure 1 , beat 1 (figure 27$).{ }^{173}$

II. "When the air is thin with frost / I blow rings of ice smoke..."

The second movement of First Lines begins with a unison attack between the flute and piano, and a flute gesture that is repeated twice (figure 29).

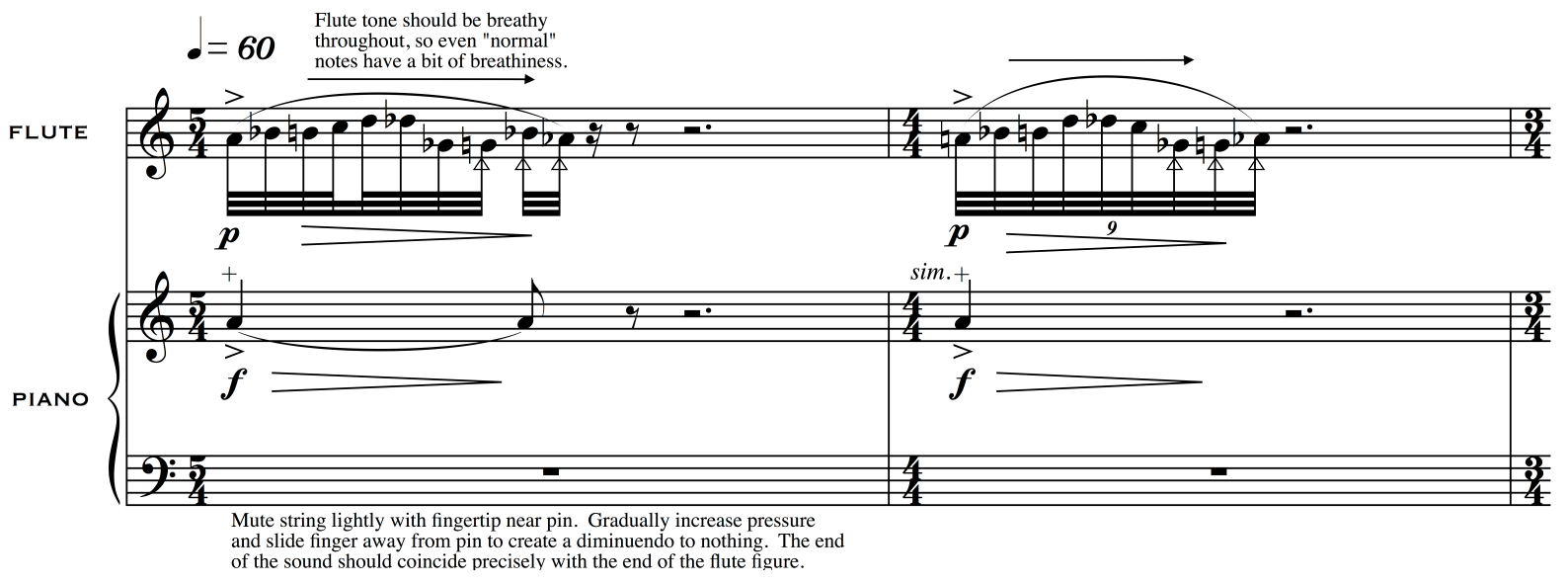

Figure 29

Williams indicates that the "flute tone should be breathy throughout, so even 'normal' notes have a bit of breathiness"175 (figure 29). To achieve this effect on the flute, one can also "release the

\footnotetext{
${ }^{170}$ Ibid.

${ }^{171}$ Williams, First Lines, 2.

${ }_{173}$ Ceccomori, interview by author.

${ }^{173}$ Goodman, interview by author.

${ }_{175}^{174}$ McElroy, Travelling Music, 87.

${ }^{175}$ Williams, First Lines, 3.
} 
drawstring of [the] lips, ${ }^{176}$ or relax the embouchure as the tone moves from more to less focused. An increase in the pressure from the diaphragm might also help, ${ }^{177}$ as well as moving the lips forward, and allowing the tongue to rise in the oral cavity, creating a hissing sound ${ }^{178}$ as the air moves across the embouchure hole that makes the timbral modification more effective and audible, especially in measures 3 and 4 where Williams indicates that the gesture should crescendo, rather than decrescendo as in the two previous iterations (figure 30).

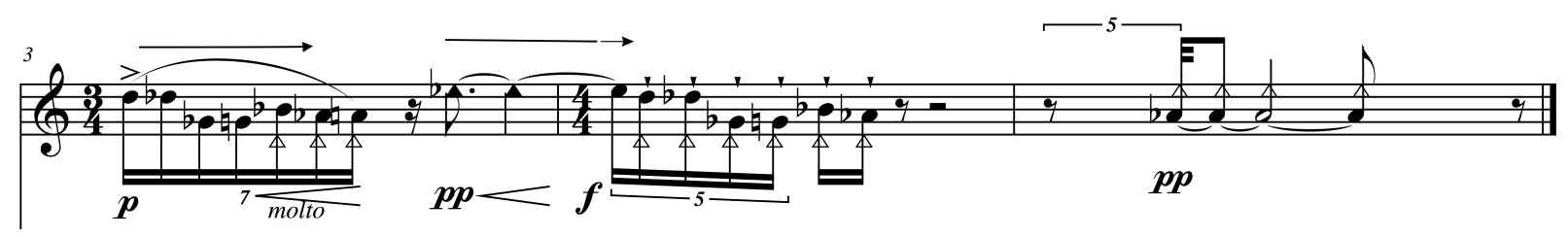

Figure 30

The flutist can consider raising the airstream with the embouchure to make a breathier sound and lowering it for a more focused sound. ${ }^{179}$

III. "the air hums at night/ the wings of bees / beg for entrance at my ears..." "180

Singing and playing simultaneously is the primary technique used in the flute part in Movement III. Williams indicates to "sing in unison (or an octave below). Voice should be an almost inaudible coloring of the flute sound. Fade in voice after flute. Fade out voice before flute. A vowel should be chosen to closely resemble the flute sound""181 (figure 31).

${ }^{176}$ Goodman, interview by author.

${ }_{178}^{177}$ Ceccomori, interview by author.

${ }_{178}^{178}$ Goodman, interview by author.

179 Almarza, interview by author.

${ }_{181}^{180}$ Derricotte, Captivity, 41.

${ }^{181}$ Williams, First Lines, 4. 


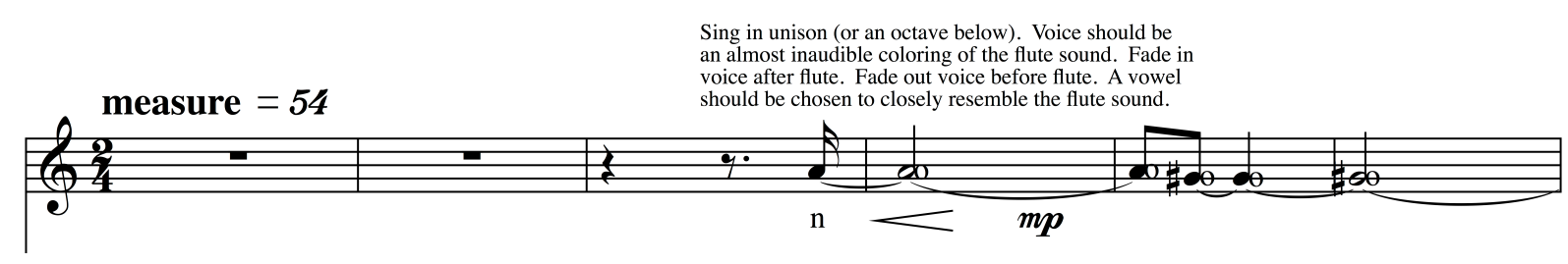

Figure 31

It is likely that singing and playing simultaneously is a technique that the flutist will have encountered prior to studying this piece. Robert Dick's definition of this technique requires the flutist to "hum while playing single pitches, creating multiple sonorities that are often heard with very pronounced modulation." "182 In First Lines, Williams insures that the correct pitch can be sung with minimal difficulty by asking the voice to be added after the sound has begun on the flute. This makes it very easy for the flutist to match the vocal pitch with the flute pitch. ${ }^{183}$ Goodman recommends quietly blowing across the embouchure hole while fingering the upcoming pitches to help audiate the correct note to be sung. ${ }^{184}$ This should be done almost as a whistle tone, at a dynamic level only audible to the flutist. For the vowel sound, Goodman recommends using the syllable "ew," to obtain a more pure timbre. ${ }^{185}$ This "lifts your soft palate more and drops your jaw down, and frees the space in between your molars. That creates enough space for both things to resonate within. ${ }^{, 186}$ Goodman also recommends practicing singing and playing in daily practice of Marcel Moyse's De La Sonorité (figure 32).

\footnotetext{
${ }^{182}$ Dick, The Other Flute, 143.

${ }_{183}^{183}$ Ceccomori, interview by author.

${ }^{184}$ Goodman, interview by author.

${ }^{185}$ Ibid.

186 Ibid.
} 


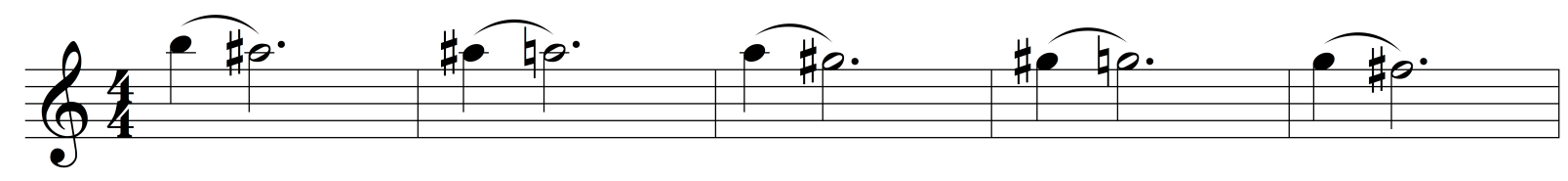

Figure 32

Practice the above exercise in the following manner:

1. Play one of the two-note figures.

2. Sing the notes in an octave most comfortable for your vocal range without the flute.

3. Engage the vocal cords and sing and play the pair of notes simultaneously.

4. Play the two-note figure without singing. ${ }^{187}$

Robert Dick also suggests practicing the first exercise from Paul Taffanel's and Philippe Gaubert's 17 Grands Exercises Journaliers de Mecanisme (figure 33) in the same manner. ${ }^{188}$

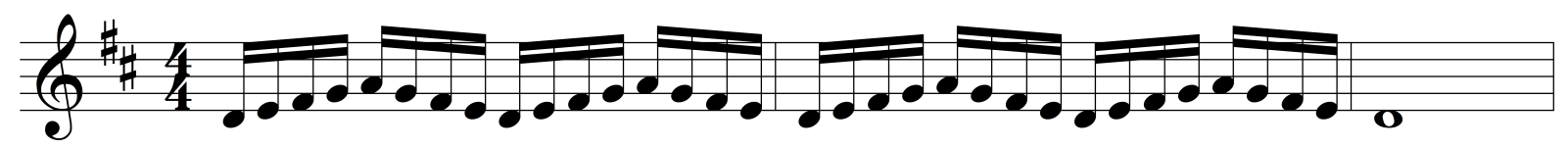

Figure 33

It can be difficult to diminuendo while singing and playing, as directed by Williams in measures $7,12,20$, and 24 (see measure 7 in figure 34 for one example).

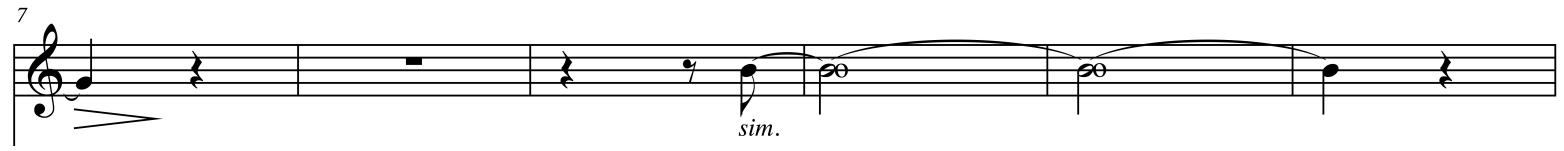

Figure 34

To accomplish this, Goodman relies on her training as a vocalist. She suggests pursing the lips and moving them forward, as one typically does to avoid becoming flat in a diminuendo, while

${ }_{188}^{187}$ Almarza, interview by author.

${ }^{188}$ Goodman, interview by author. 
also drawing the voice "through the back of your head through an imaginary dunce cap that points $45^{\circ}$ to the rear, and allowing the space to open up that way." ${ }^{\prime 189}$ Lessening the pressure of the flute on the lips also keeps the pitch from becoming too flat. ${ }^{190}$

All three of the flutists interviewed recommended simply watching the piano part while tracking the downbeats to stay coordinated throughout the movement (figure 35).

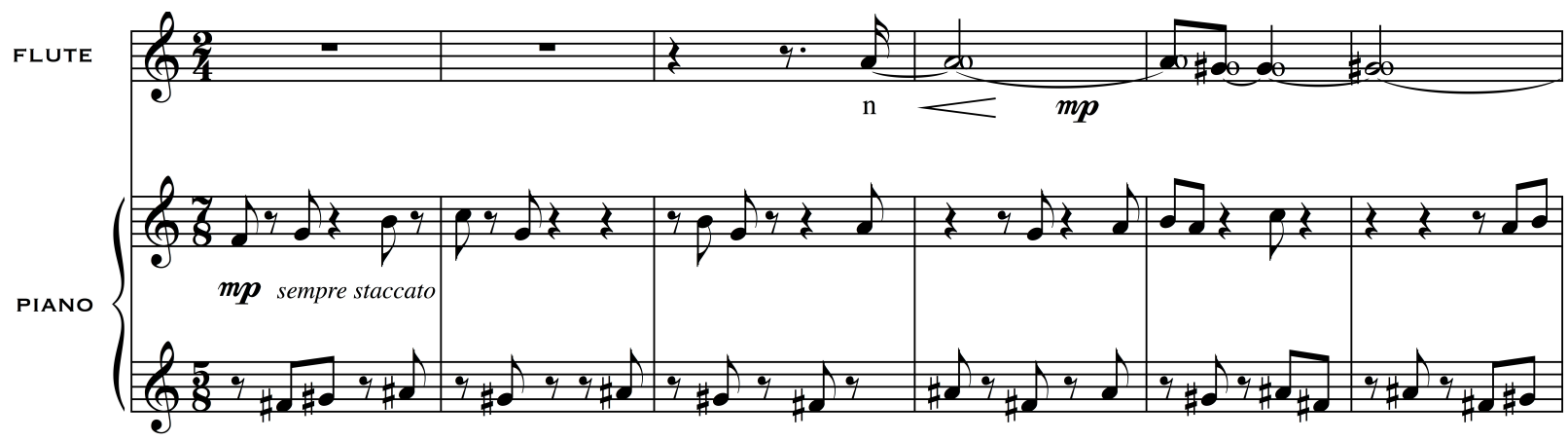

Figure 35

IV. "In the margins you roam free... ${ }^{191}$ The old neon flickers and hums... ${ }^{192, "}$

Rhythmic complexity presents the primary challenge of movement IV. In addition to complicated rhythmic figures, the flute and piano perform at different tempi, with an indication of a quarter note speed of 50 beats per minute in the piano, and 60 beats per minute in the flute part. Also, beginning in measure 3 the meters are different, with the piano in 5/4 and the flute in 6/4 (figure 36).

\footnotetext{
189 Ibid.

190 Almarza, interview by author.

${ }^{191}$ Chin, Rhapsody in Plain Yellow, 92.

${ }^{192}$ Chin, Rhapsody in Plain Yellow, 77.
} 


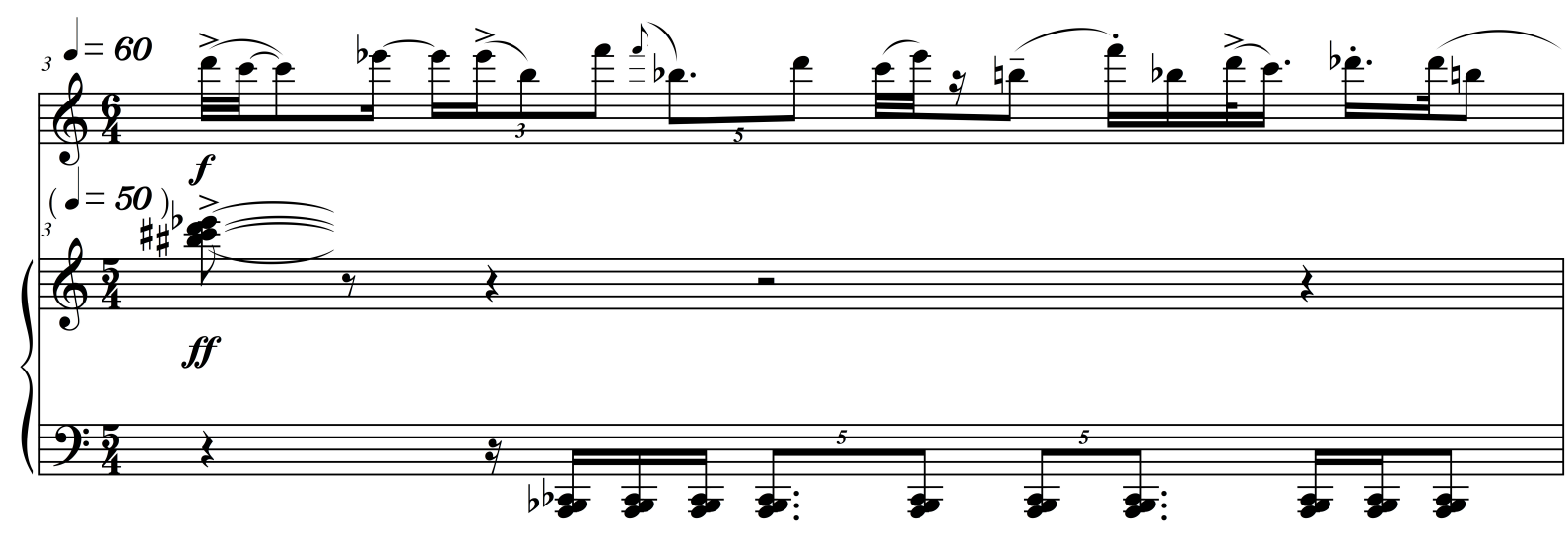

Figure 36

The flute rests during measures 1 and 2, and s/he can use this time to lock into the piano tempo, and then subdivide 6 over 5 for the duration of the movement. ${ }^{193}$

Williams assists by using dotted lines to reinforce where the flute and piano should be absolutely sure to line up, as in the flute's second beat in measure 5 (figure 37).

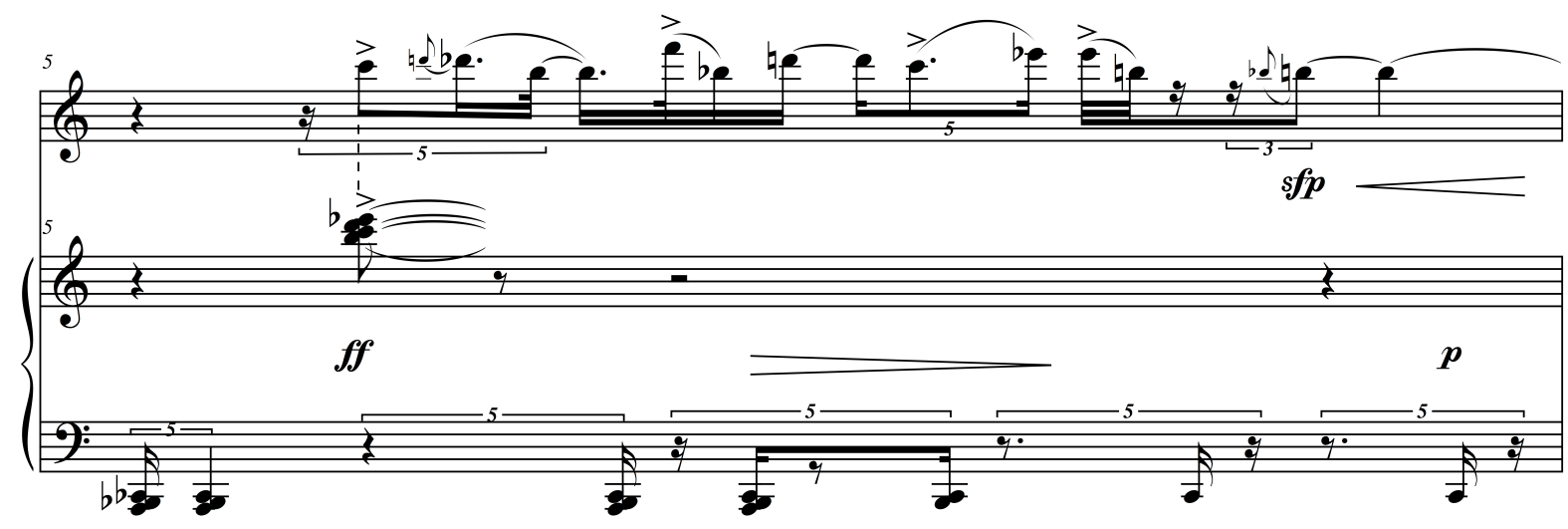

Figure 37

The figures are gestural, and carefully subdividing and thinking of an eighth-note beat will guarantee that all are performed accurately. ${ }^{194}$ The only extended technique required of the flutist is the pitch bend in measure 9 (figure 38).

${ }^{193}$ Goodman, interview by author. 


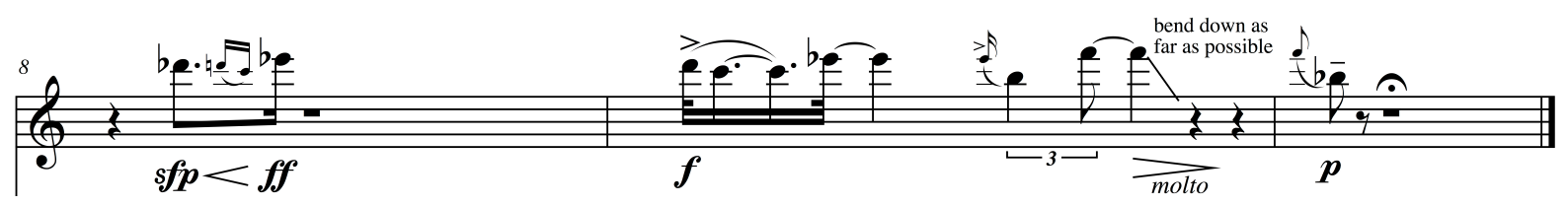

Figure 38

To accomplish this, a three-fold approach is recommended. The flutist can try the following techniques, to occur in tandem:

1. Beginning in the default set-up position, roll the flute towards the body using the hands.

2. Duck the chin down towards the chest as much as possible.

3. Direct the air stream as far as possible toward the feet. ${ }^{195}$

Any one of these methods alone will not create an adequate pitch bend, but all three will create a large enough change, and fulfill Williams' request to "bend down as far as possible.",196

In Movement IV, Williams instructs the pianist to depress "chromatic clusters" before measure 1 (figure 39). ${ }^{197}$

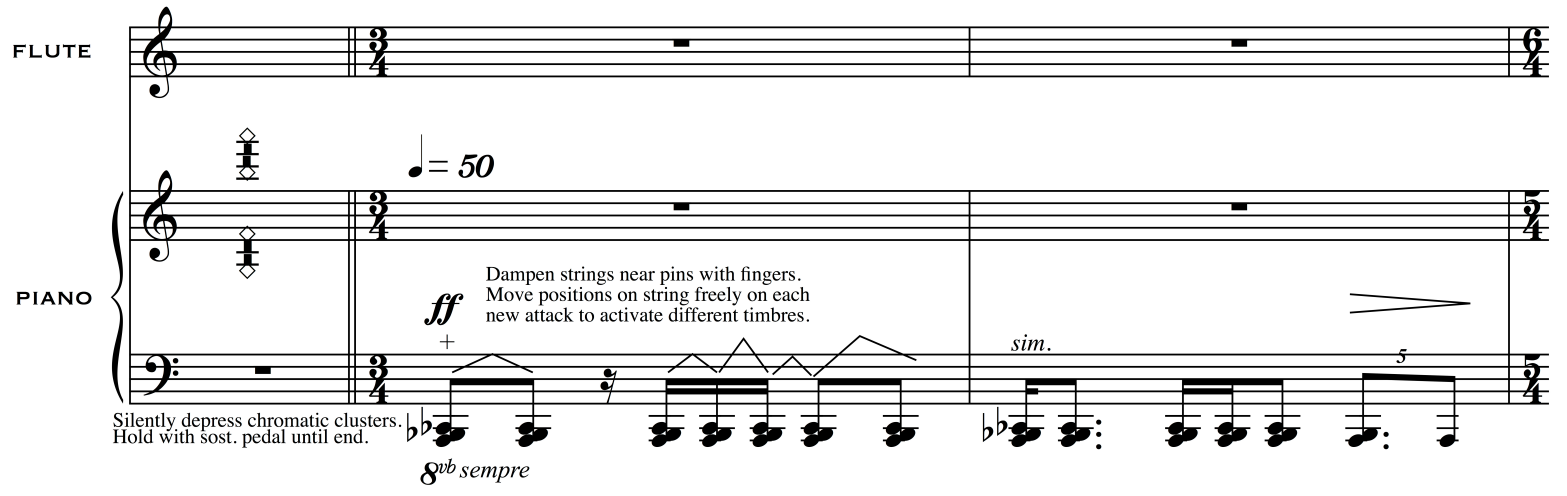

Figure 39

\footnotetext{
194 Almarza, interview by author.

195 Ibid.

${ }^{196}$ Williams, First Lines, 7.

${ }^{197}$ Williams, First Lines, 6.
} 
She continues: "Dampen strings near pins with fingers. Move positions on string freely on each new attack to activate different timbres." ${ }^{198}$ This technique occurs throughout, with the exception of beats 4 and 5 in measure 7, and all of measure 8 . In those places, the strings should remain dampened but the hand should not move. Williams feels that no further explanation is needed, as pianists correctly perform the technique whether or not they have played for her in advance of a performance or recording. ${ }^{199}$

V. "That half is almost gone, / the Chinese half..."200

In the first eight measures of Movement $\mathrm{V}$, the flutist must articulate crisply to match the attacks in the piano, ${ }^{201}$ as the two voices are hocketed to create a composite rhythm (figure 40).

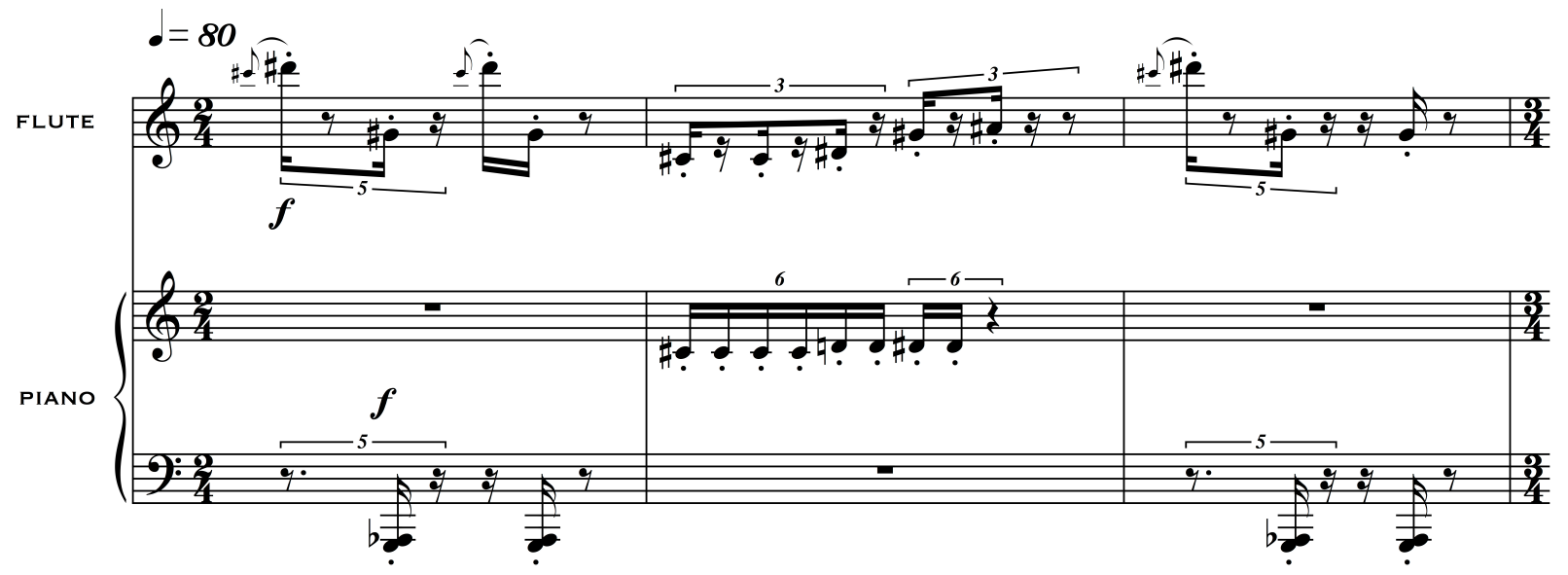

Figure 40 (continued on the next page)

\footnotetext{
${ }^{198}$ Williams, First Lines, 6.

${ }^{199}$ Williams, interview by author, 24 January 2014.

${ }^{200}$ Chin, Rhapsody in Plain Yellow, 17.

${ }^{201}$ Williams, interview by author, 24 January 2014.
} 

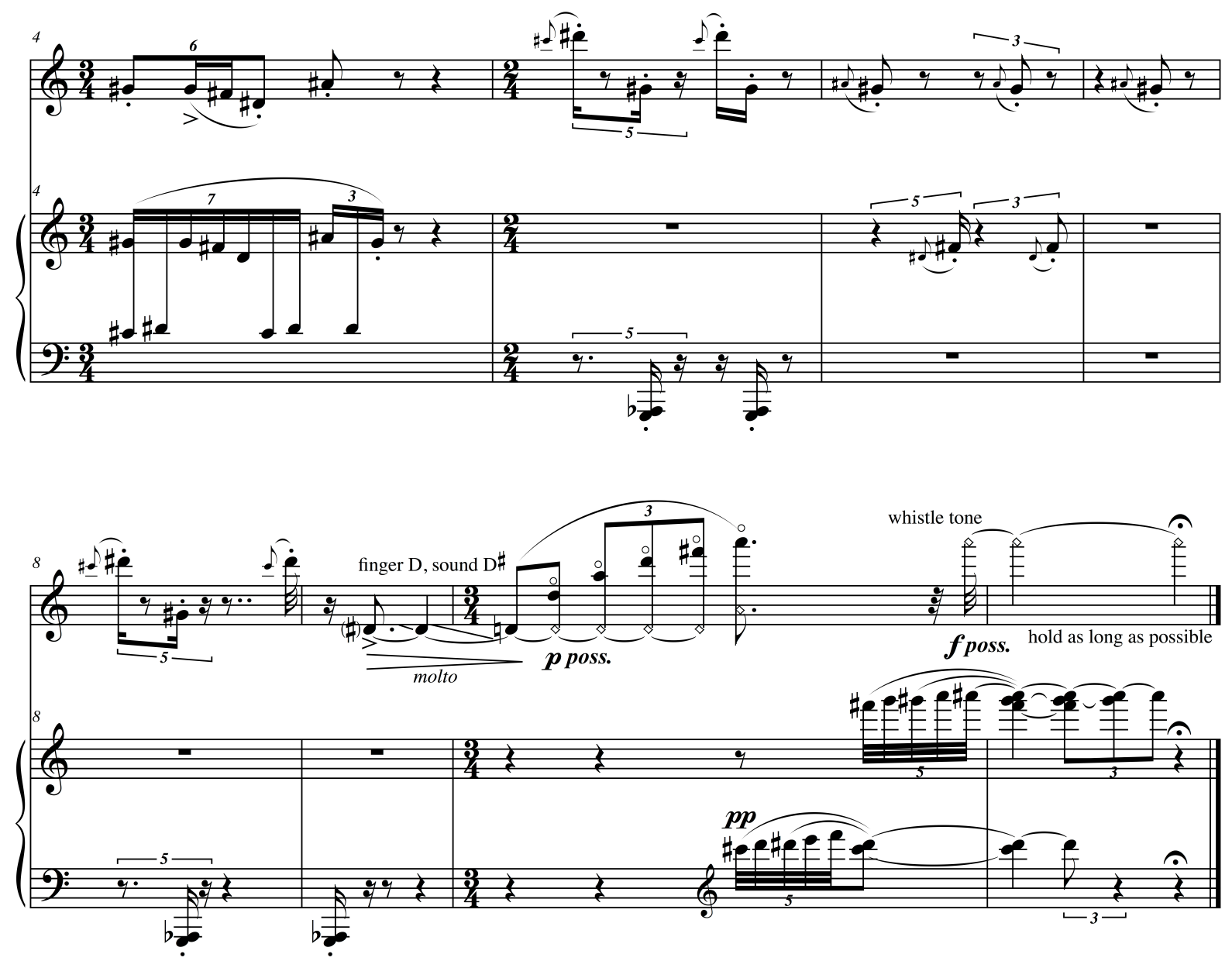

Figure 40 (continued)

This is especially challenging when the flutist is in unison with the piano in the lowest register, between $\mathrm{C \# 4}$ and $\mathrm{A \# 4}$, where tone can be less focused and attacks tend to be late. For the best chance of matching the piano, the flutist can "try to have as much core to the sound as possible" imagining a sound reminiscent of "stainless steel ball bearings, perfectly cylindrical, round, [and] packed." 202 Moving the point of articulation lower in the mouth can also assist with the immediacy of the articulation. ${ }^{203}$

${ }^{202}$ Goodman, interview by author.

${ }^{203}$ Almarza, interview by author. 
The flute's pitch bend in measure 9 (figure 41) can be accomplished by fingering D4, but with the right hand fourth finger only depressing the ring of the key.

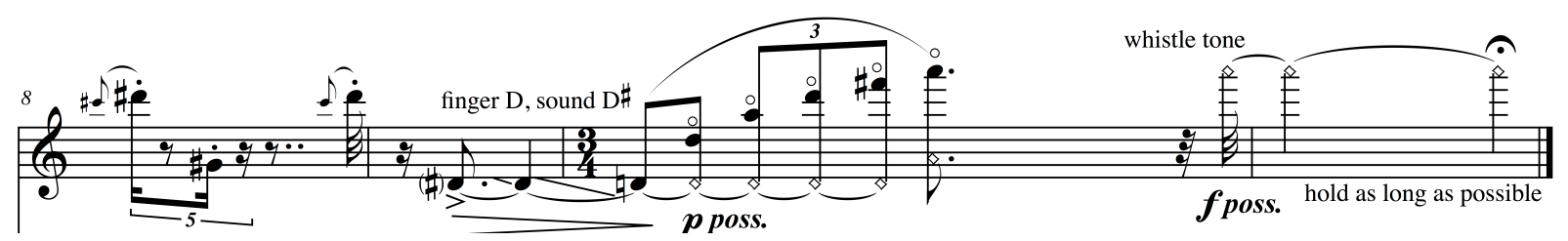

Figure 41

The flutist can then slowly slide the finger over the key hole, landing on D4 by the downbeat of measure $10 .{ }^{204}$ Begin measure 9 with both the chin and airstream lifted, and then adjust to the default playing position to make pitch bend noticeable, a challenge, as pitch is less flexible in the lowest register of the flute. ${ }^{205}$ The D\#6 in measure 8 can be used as a reference pitch to check the accuracy of the D\#4 at the start of measure 9 (figure 41). ${ }^{206}$

In measure 10, Williams instructs the flutist to play the D harmonic series, using the D4 fingering as the fundamental for the first four harmonics, and switching to A4 on beat 3 (figure 41). To gain dexterity in performing harmonics, incorporating their practice into the flutist's daily routine is recommended. ${ }^{207}$ This can easily be done as daily warm up, with the flutist picking a different pitch each day, from $\mathrm{C} 4$ to F4, and slowly ascending and descending the harmonic series while focusing on changes in embouchure, especially as related to air direction (figure 42). ${ }^{208}$

\footnotetext{
${ }^{204}$ Almarza, interview by author.

${ }_{205}^{205}$ Goodman, interview by author.

${ }^{206}$ Ibid.

${ }_{207}^{207}$ Almarza, interview by author.

${ }^{208}$ Ibid.
} 
Finger low D and produce upper pitches as harmonics.

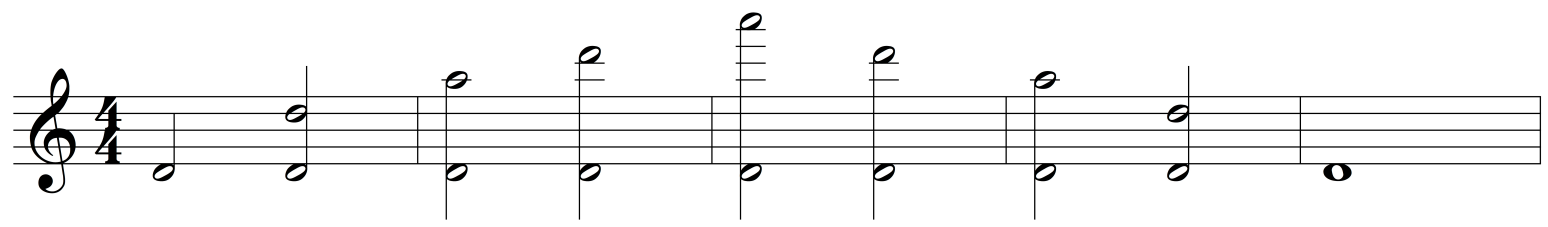

Figure 42

Depending on the particular make and model of the instrument, one might consider alternate fingerings in measure 10 of Movement V (figure 41) to facilitate the series and assist in correcting any pitch inaccuracies. Some options include the following:

- $\quad$ On D6, move to the G4 fingering for ease ${ }^{209}$

- Using D4 as the fundamental fingering, the F\#6 will tend to be flat. Move to the F\#4 fingering to produce a sharper, more in tune harmonic. ${ }^{210}$

- $\quad$ On F\#6, one can also move to the B4 fingering for ease and to correct the pitch ${ }^{211}$

- $\quad$ On A6, add the F key plus the C\# key for ease of production ${ }^{212}$

Practicing whistle tones is an excellent method for improving tone, ${ }^{213}$ and the final flute pitch in movement $\mathrm{V}$ (measure 11 in figure 41) provides a reason to incorporate them into daily practice. ${ }^{214}$ By minimizing the pressure of the flute on the lower lip, moving the lips forward away from the teeth, and aiming the airstream high across the embouchure hole, ${ }^{215}$ the whistle tone will occur. The flutist can incorporate whistle tones into his or her daily routine, beginning

\footnotetext{
${ }^{209}$ Almarza, interview by author.

${ }^{210}$ Goodman, interview by author.

211 Almarza, interview by author.

212 Ibid.

${ }^{213}$ Dick, The Other Flute, 140.

214 Almarza, interview by author.

215 Ibid.
} 
on B6, and practicing descending half-steps as outlined in Moyse's first exercise from De La Sonorité, but with fingerings one octave higher ${ }^{216}$ (figure 43).

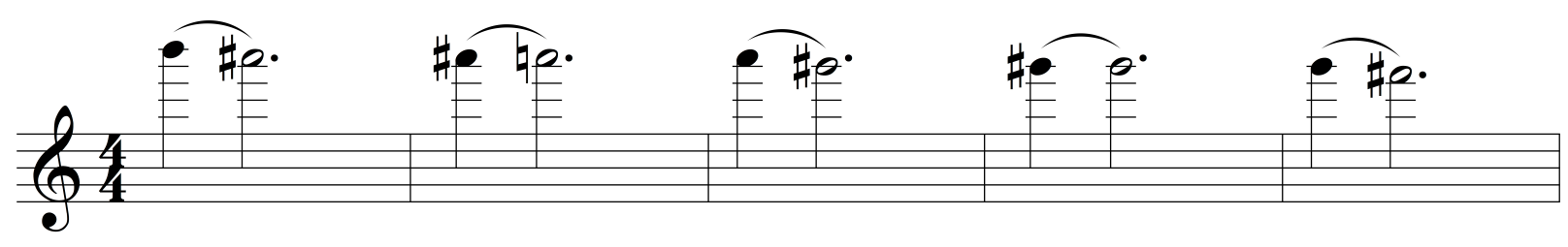

Figure 43

In preparation for the whistle tone in First Lines, one can think "more of a whistle tone embouchure than a harmonic embouchure" ${ }^{217}$ by the end of measure 10, while lifting the soft palette in the oral cavity and thinking resonance in the top half of the mouth. ${ }^{218}$ Using A6 as the fingering, as suggested by Williams in the score, is recommended. ${ }^{219}$

VI. "Shhh, my grandmother is sleeping...,220

Movement VI is easiest to relate to the text used, ${ }^{221}$ and begins with a flurry of activity between the flute and piano, creating an event that needs to be hushed. During beat 2 of measure 1, the flutist is required to slide from E-flat6 to F6 (figure 44), and this can be accomplished by sliding the middle finger of the left hand off of the keyhole, while depressing the key's ring. ${ }^{222}$

\footnotetext{
${ }^{216}$ Almarza, interview by author.

${ }^{217}$ Goodman, interview by author.

${ }^{218}$ Ibid.

${ }^{219}$ Ibid.

${ }^{220}$ Chin, Rhapsody in Plain Yellow, 41.

${ }^{221}$ Williams, interview by author, 24 January 2014.

${ }^{222}$ Almarza, interview by author.
} 


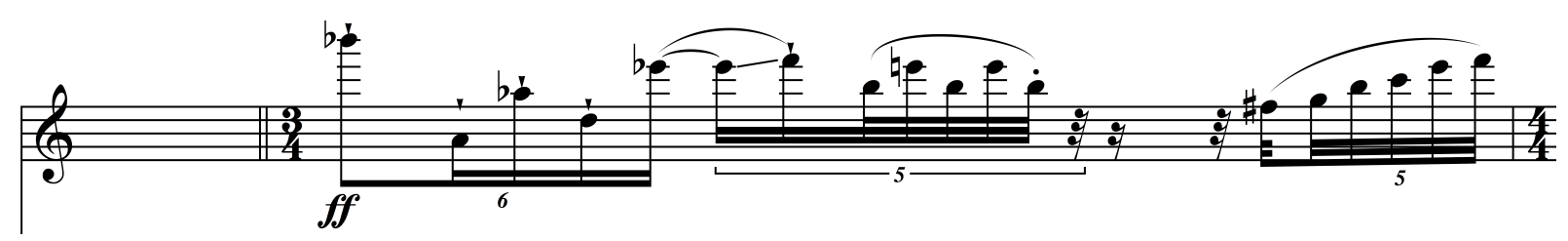

Figure 44

The head and airstream can be manipulated to correct any pitch issue caused by the use of the alternate fingering. The very fast quintuplet later in that beat can be executed by simultaneously moving the second finger of the left hand and both trill keys to facilitate E6.

Beginning in measure 3, the flutist abandons methods for traditional tone production, and instead is instructed to "inhale" and "exhale" with the mouth completely covering the embouchure hole ${ }^{223}$ (figure 45).

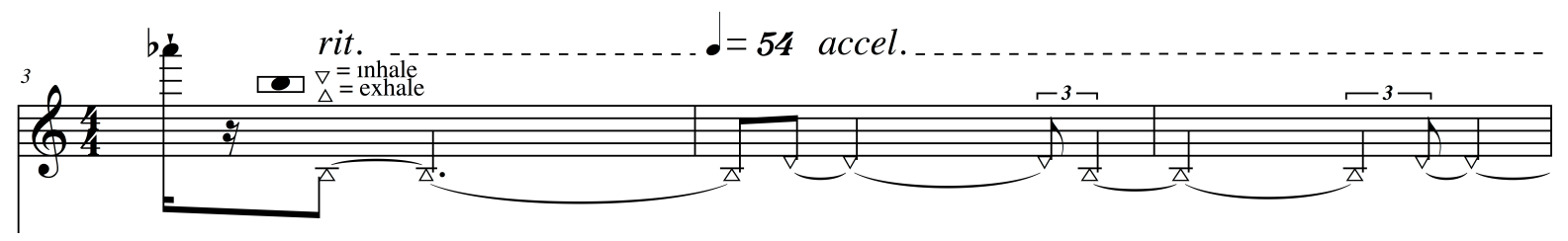

Figure 45

Beginning with an exhalation, a very large breath should be taken after the A-flat6 in measure 3. Using a 'sh' sound will give the sound more weight. ${ }^{224}$ Although the technique is fairly simple to execute, breath support can be an issue in this movement. Inhalation produces less sound than the exhalation, and Goodman recommends "closing down [the] jaw to increase the volume of the inhalations, ${ }^{, 25}$ which can limit the amount of air one takes in to prepare for the subsequent exhale. In order to navigate this challenge, additional breaths may be added in measure 4 after

\footnotetext{
${ }^{223}$ Williams, First Lines, 10.

${ }^{224}$ Goodman, interview by author.

${ }^{225}$ Ibid.
} 
the triplet on beat 4 (figure 45), measure 7 following the downbeat, measure 8 after the $C 4$, and measure 10 after the B (figure 46). ${ }^{226}$

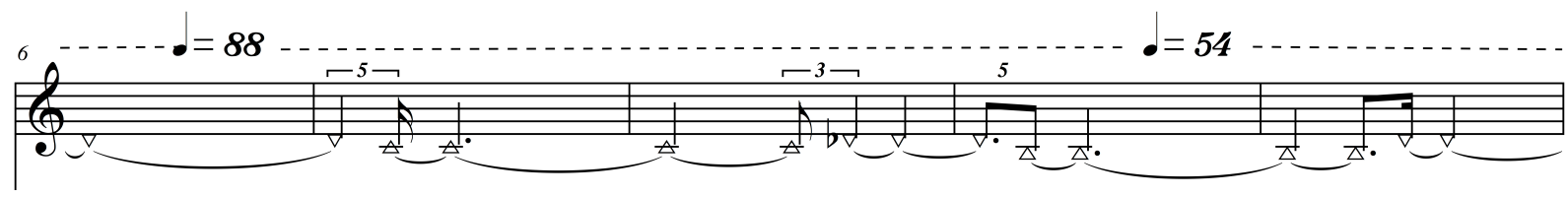

Figure 46

Measure 18 contains a direction to "stop suddenly,"227 representing a moment of apnea, in which the grandmother stops breathing momentarily (figure 47). ${ }^{228}$

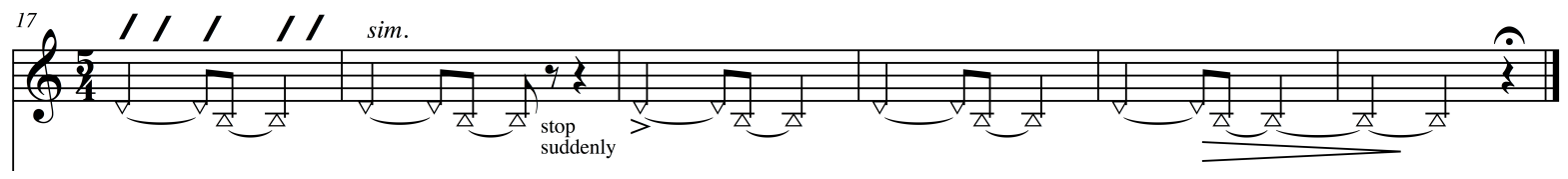

Figure 47

This should be a surprising moment in the movement, ${ }^{229}$ and the suspense can be heightened in the following ways: the flutist can close his/her throat to end the B3 on beat $3,{ }^{230}$ or the sound can be stopped with a tongue ram, thrusting the tongue into the embouchure hole. ${ }^{231}$ If the latter method is chosen, the flutist might consider inhaling through the nose during the quarter rest, as to leave the tongue undisturbed so that it can be withdrawn on the downbeat of measure nineteen to make the moment where the breathing begins again more dramatic. ${ }^{232}$

\footnotetext{
${ }^{226}$ Goodman, interview by author.

227 Williams, First Lines, 11.

${ }^{228}$ Williams, interview by author, 24 January 2014.

${ }^{229}$ Ibid.

${ }^{230}$ Almarza, interview by author.

${ }^{231}$ Goodman, interview by author.

232 Ibid.
} 
VII. "And sometimes, when the sun stands up / Right out of the ground..."233

The most straightforward in terms of flute technique, Movement VII is perhaps the most complex in terms of rhythm. The flute and piano primarily play in unison rhythm throughout, but subito tempo changes occur every two to three bars. While it may be tempting to rehearse this under tempo with the pianist, it is recommended that each performer work individually to accurately switch to the new tempi, and trust that the other musician will move in tandem. ${ }^{234}$ This is an instance where practicing slowly might not help the ensemble's cohesion. With the exception of measures 8 and 11, the overall meter is three. However, different subdivisions and irregular beat lengths are used throughout the movement, including 4:5, 5:4, and 7:4 (figure 48), to create a controlled flexibility within each measure that requires careful practice with metronome, and vigilant subdivision on the part of both performers. ${ }^{235}$

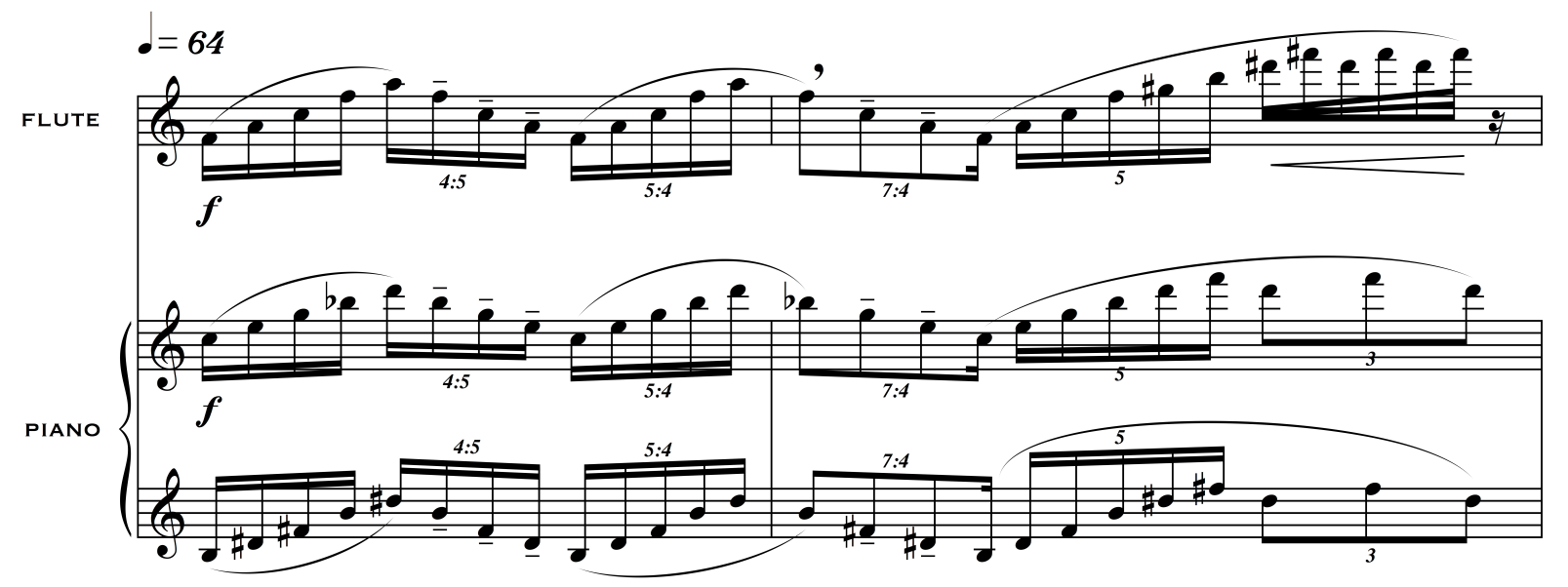

Figure 48

Williams writes trills and tremolos at various points throughout the movement, and the following fingerings are recommended:

${ }^{233}$ Goedicke, Listen, Love, 33.

${ }_{234}^{234}$ Goodman, interview by author.

${ }^{235}$ Almarza, interview by author. 
- $\quad$ Measure 2: D\#6 - F\#6 - regular fingerings ${ }^{236}$

- $\quad$ Measure 5: G-flat6 - A-flat6 - left hand index finger and thumb

- Measure 8: G5 - E-flat5 - regular fingering, but leave the left hand index finger down

- $\quad$ Measure 10: B5 - G\#5 - finger G\#, and trill the left hand middle finger ${ }^{237}$

Williams ends this movement with the flute playing B3. For the flutist without a B-foot joint, the last three notes may be taken up one octave to $\mathrm{B} 4 .^{238}$

VIII. “Gestures made against snow: / The fling / And scatter of birdseed onto burned grass... „239 Intended as a movement primarily for piano, ${ }^{240}$ the flute plays a minor role in Movement VIII, only playing seven notes in measures 11 and 12 as a "gestural comment"241 (figure 49).

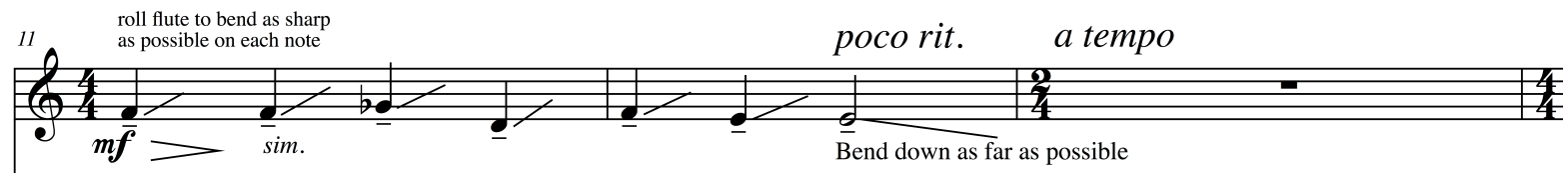

Figure 49

Each quarter note involves a pitch bend up, and the flutist is directed to "roll flute to bend as sharp as possible on each note" ${ }^{242}$ If not for the G-flat4 on beat 3 of measure 11, it might be possible to slide the finger from the key hole while keeping the key ring depressed to exaggerate the change in pitch. However, for consistency of timbre, the pitch bends should be facilitated by

${ }^{236}$ Goodman, interview by author.

237 James Pellerite, A Modern Guide to Fingerings for the Flute, Second Edition, (Van Nuys, Alfred, 1964), 19.

${ }^{238}$ Williams, interview by author, 24 January 2014.

${ }^{239}$ Goedicke, Listen, Love, 38.

${ }^{240}$ Williams, interview by author, 24 January 2014.

241 Ibid.

${ }^{242}$ Williams, First Lines, 15. 
lifting the chin, rolling out the flute, and raising the air stream only. ${ }^{243}$ The flutist should be sure to keep strictly in time, and prioritize steady tempo over executing the pitch bends. ${ }^{244}$

IX. "First it is only the sense of sunlight/ Creeping up over the dunes... "245

Two versions of Movement IX exist: one has a pitch center of D, and one uses E as its pitch center. Williams prefers the version centered on E, "transposing to make it possible to get those trills really distinct, especially the quarter-tone, timbral"246 trills (figure 50).

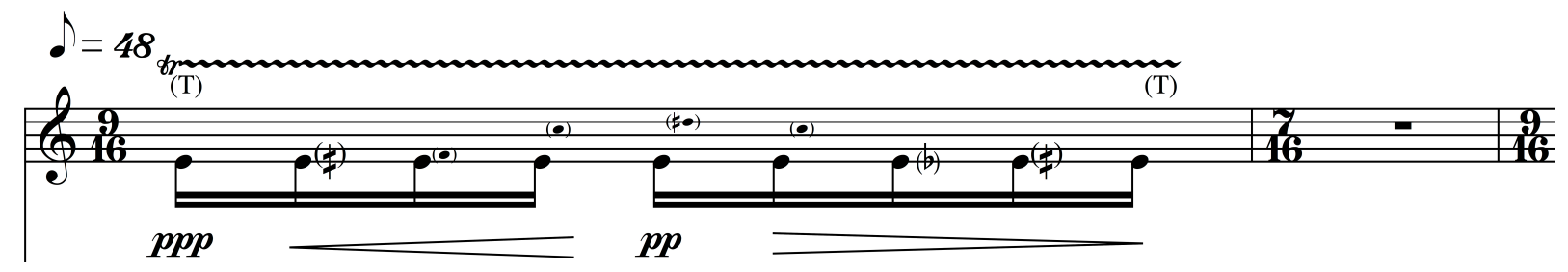

Figure 50

The series of timbral trills and tremolos included in this atmospheric ${ }^{247}$ movement occurs nine times, and includes five separate trills. The following suggestions for fingerings were compiled from James Pellerite's A Modern Guide to Fingerings on the Flute:

- $\quad$ E4 timbral trill: Finger low E, and trill the keys on the footjoint, using the lowest possible fingering on the flute (C4 or B3, depending on whether or not the instrument has a C-footjoint or B-footjoint).

- $\quad$ E4 timbral trill: Slide the middle finger of the right hand to cover and uncover the key hole on the E key, keeping the key ring depressed.

\footnotetext{
${ }^{243}$ Ceccomori, interview by author.

${ }^{244}$ Goodman, interview by author

245 Goedicke, Listen, Love, 51.

246 Williams, interview by author, 24 January 2014.

247 Ibid.
} 
- $\quad$ E4-F4: Finger low E and trill the middle finger of the right hand. This is the standard E4-F4 trill.

- $\quad$ E4-C5: Finger E4, and move the thumb and middle finger on the left hand and first finger of the right hand simultaneously.

- $\quad$ E4-D\#5: Finger E4, and trill the left hand thumb and index finger and second trill key with the right hand, using the ring finger, simultaneously. ${ }^{248}$

For additional suggestions, consult A Modern Guide to Fingerings for the Flute by James Pellerite's or The Other Flute by Robert Dick.

For the majority of this movement, the flute's dynamic range only extends from ppp to $p p$, with a crescendo/descrescendo hairpin indicated with each series of trills, indicating that shape should be a priority for the flutist. ${ }^{249}$ The exception to this dynamic indication occurs in measure 14, where the flute should crescendo from ppp to ff, and then decrescendo to $p p$ (figure 51).

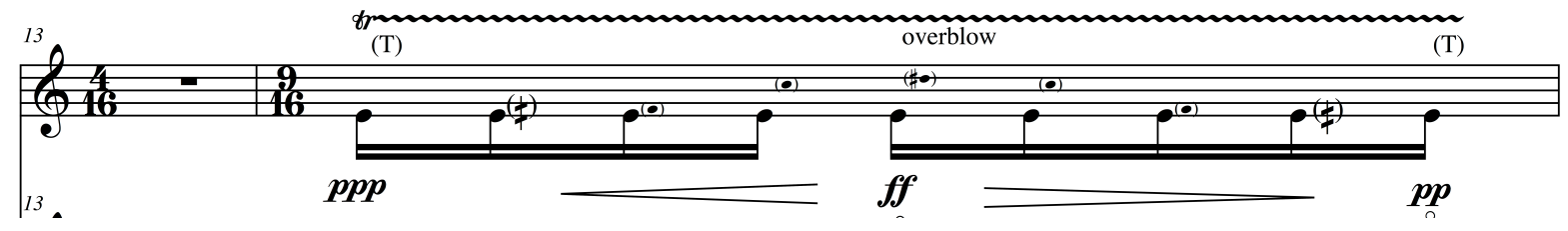

Figure 51

During this measure, Williams indicates that flutist should "overblow" ${ }^{250}$ while trilling. To accomplish this, Goodman suggests overblowing "along the harmonic series, so each note in the sequence sounds at the next partial in the series, and then reverse it in the second half of the

${ }_{248}^{248}$ Pellerite, A Modern Guide to Fingerings for the Flute, 32.

${ }^{249}$ Almarza, interview by author.

${ }^{250}$ Williams, First Lines, 17. 
measure as the line descends." ${ }^{, 251}$ Therefore, the first trill in measure 14 sounds as written, the second trill is overblown at the first partial, the third is the second partial, and so on. Increasing the "amount of support, which naturally results in more air traveling through the flute while maintaining the same embouchure and air direction" 252 is one recommended method for ascending the harmonic series, and this may be done in reverse after the fifth trill in measure 14. If necessary, the flutist can also consider raising the airstream to produce the higher harmonics. ${ }^{253}$ The exercise outlined in Figure 52 can also be practiced with any pitch between $\mathrm{C} 4$ and F4 as the fundamental to help facilitate this technique.

Finger low D and produce upper pitches as harmonics.

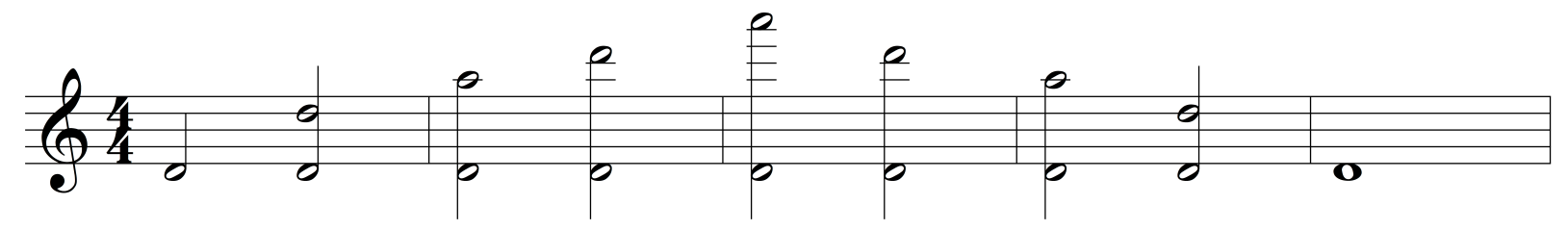

Figure 52

Measures 11 and 20 contain the only contrasting material in the piece, with a breathy C5 in the flute (figures 53 and 54).

${ }^{251}$ Goodman, interview by author.

${ }^{252}$ Ibid.

${ }^{253}$ Almarza, interview by author. 


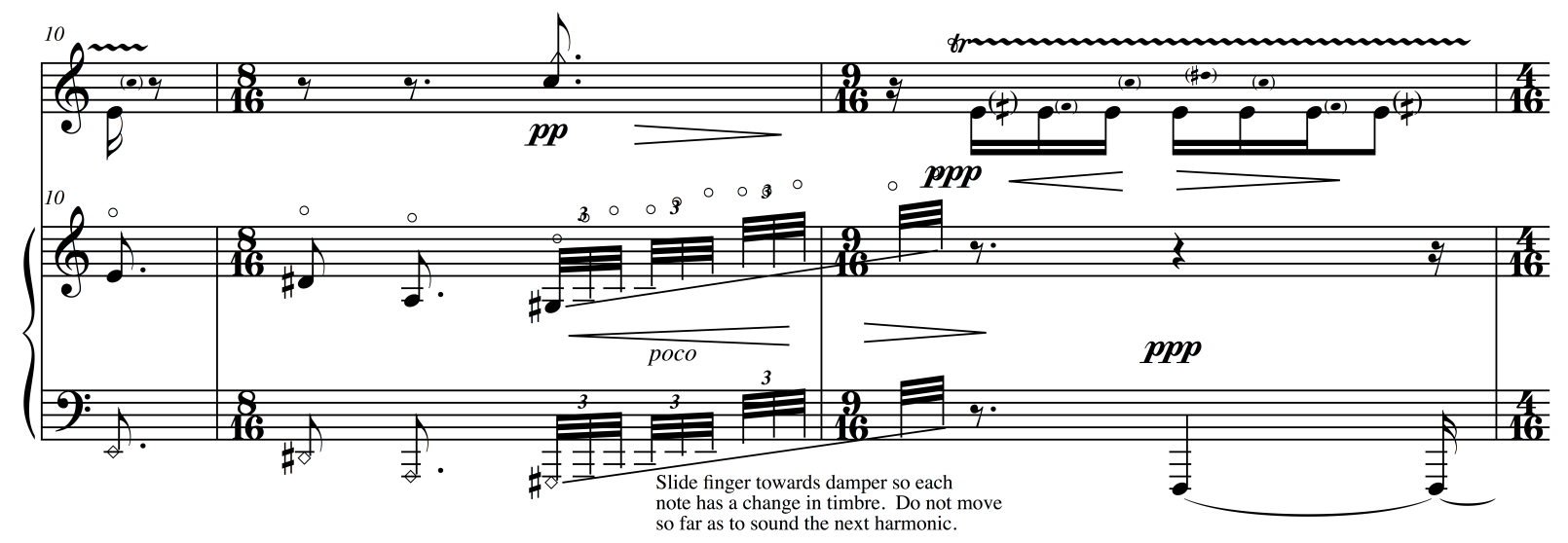

Figure 53

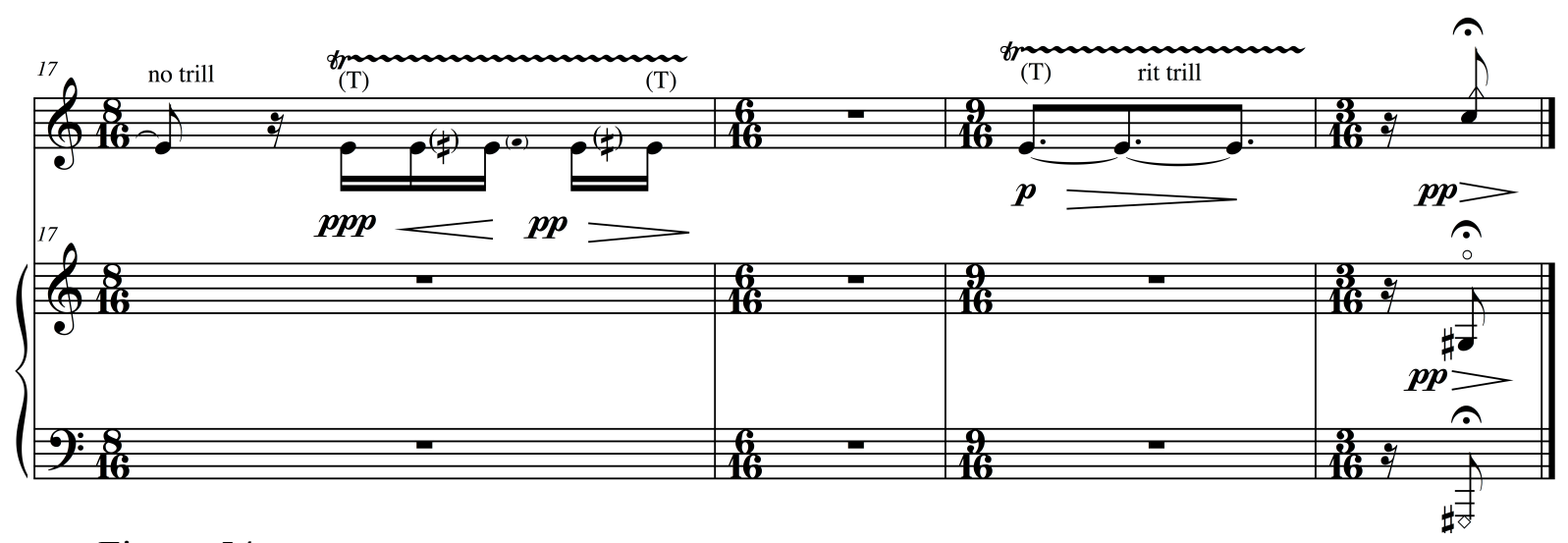

Figure 54

At the dynamic level of pianissimo,

Start gently, with minimal articulation. Even though you're trying to line up with the piano part, these shouldn't be at all accented. This isn't about dynamics; it's about color. Aim for a breathy sound with a tiny bit of tone, rather than a full tone with a little bit of air. $^{254}$

Coordinated with the $\mathrm{C} 5 \mathrm{~s}$, the pianist is instructed to "slide finger towards damper so each note has a change of timbre. Do not move so far as to sound the next harmonic"255 (figure 53). According to the composer, the pianist should play on one piano string, moving up and

${ }^{254}$ Goodman, interview by author.

${ }^{255}$ Williams, interview by author, 24 January 2014. 
down that string rather than laterally across several strings. ${ }^{256}$ The latter is the method used by Elitza Harbova employed on the recording, and should not be imitated. ${ }^{257}$

Creating the right mood of calmness and serenity can be challenging, especially considering the technical difficulties created by the trills. Williams is again specific in her tempo indication, using the eighth note as the macro beat, even though each measure has an indicated macro beat of the sixteenth note. Thinking of the larger beat unit will help this movement sound "calm and glacial" 258 rather than "jittery." ${ }^{259}$ A meter change occurs in nearly every bar, insuring the proper amount of time between musical events. Carefully subdivide and accurately count the rests, and the appropriate atmosphere should be communicated to the audience. ${ }^{260}$

$X$. "Is that only the windows creaking, Maria,/ the wounded panes in them trembling?... "261

A "bookend"262 to Movement II, Movement X makes use of traditional and timbral trills, as well as timbral modifications, to depict the sound of "windows creaking." 263 The flute and piano parts are closely coordinated, with the pianist articulating each of the flute's attacks (figure $55)$.

\footnotetext{
256 Ibid.

${ }^{257}$ Ibid.

${ }_{258}^{258}$ Goodman, interview by author.

${ }^{259}$ Ibid.

${ }^{260}$ Almarza, interview by author.

${ }^{261}$ Sedakova, The Silk of Time, 23.

${ }^{262}$ Williams, interview by author, 24 January 2014.

${ }^{263}$ Sedakova, The Silk of Time, 23.
} 

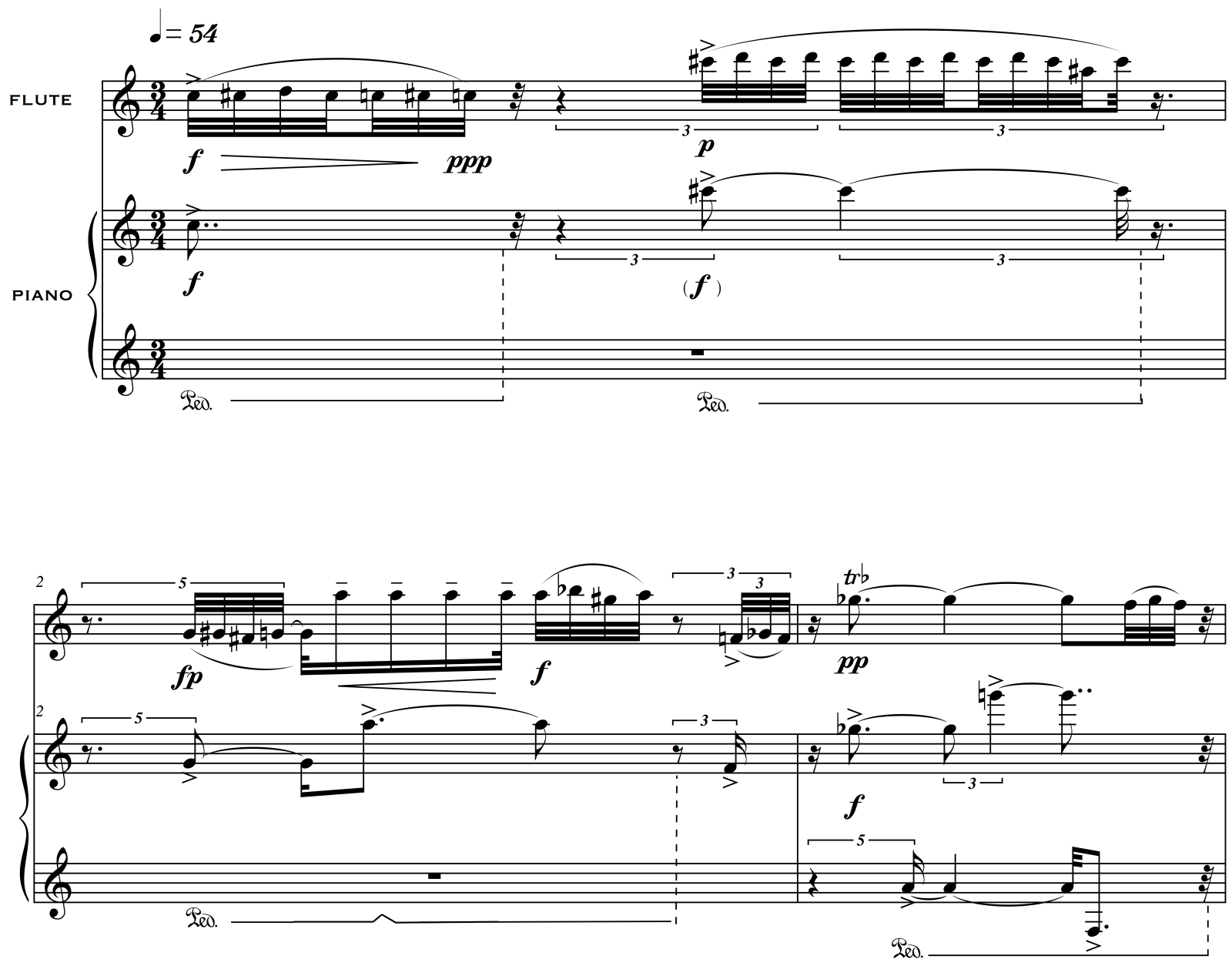

Figure 55

Measures 5 and 6 stand are exceptions (figure 56).

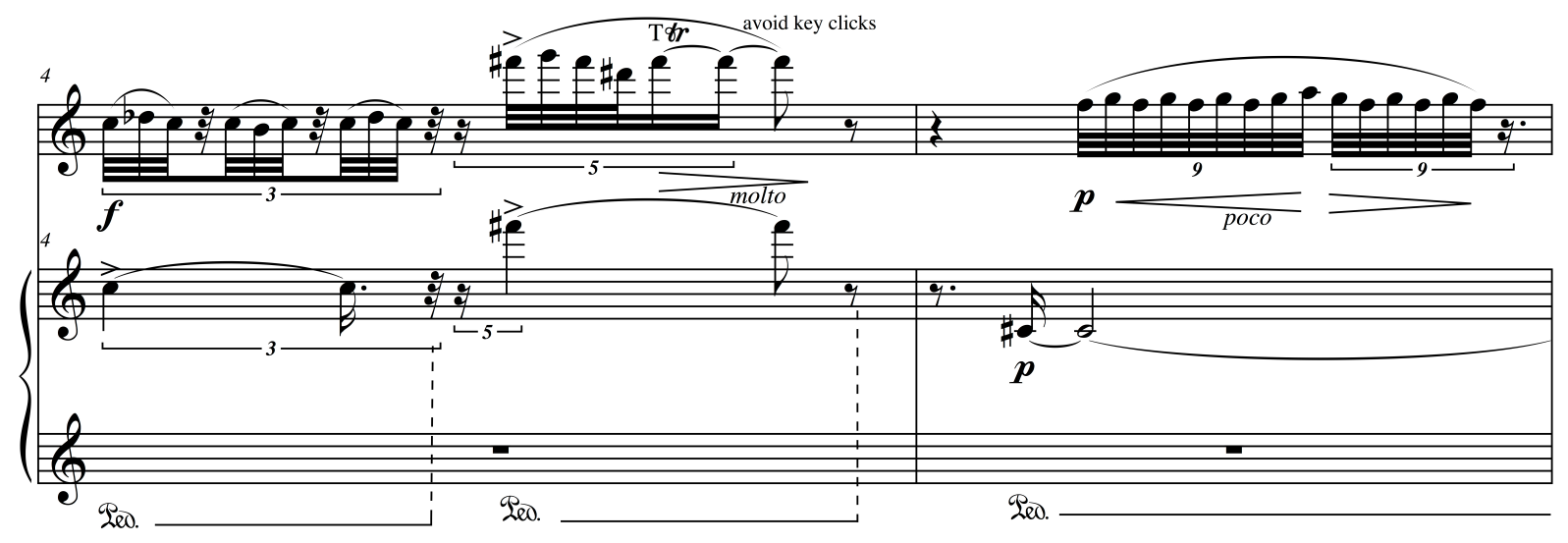

Figure 56 (continued on the next page) 


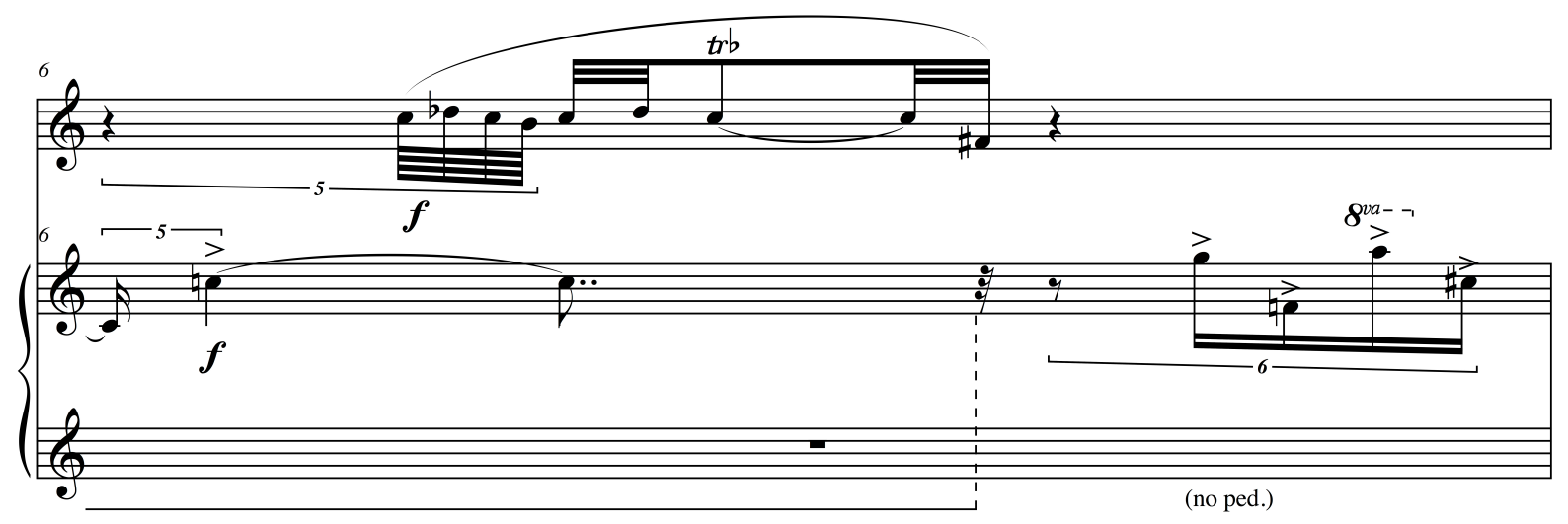

Figure 56 (continued)

To insure synchronization, the flutist should lead each attack by physically dictating each entrance. ${ }^{264}$ Because breathing can make the flutist late after several of the shorter rests, such as the downbeat of measures 2 and 3, it is suggested that a breath be taken through the nose. ${ }^{265}$ This will save the time needed to reset the embouchure, and provide an aural cue for the pianist. All of Williams' suggested fingerings for timbral modifications work well in this movement, ${ }^{266}$ and the flutist can embrace the sound of the keys clicking to reinforce the sound of the "wounded panes...trembling. ${ }^{, 267}$ Pianists should note the specificity with which Williams indicates clearing the pedal (figure 56).

XI. "I was surprised by/ how calm the waters were..."

The statement "if the harmonics are in tune, then this couldn't be a calmer sounding movement, ${ }^{269}$ hints at the primary challenge in the final movement of First Lines. Because "the

${ }^{264}$ Goodman, interview by author.

${ }^{265}$ Ibid.

${ }^{266}$ Ceccomori, interview by author.

${ }^{267}$ Sedakova, The Silk of Time, 23.

${ }^{268}$ Sedakova, The Silk of Time, 73.

${ }^{269}$ Goodman, interview by author. 
fingering of the fundamental greatly affects the timbre of the harmonics, ${ }^{, 270}$ care should be taken to follow the fingerings suggested by Williams throughout this movement (figure 57).

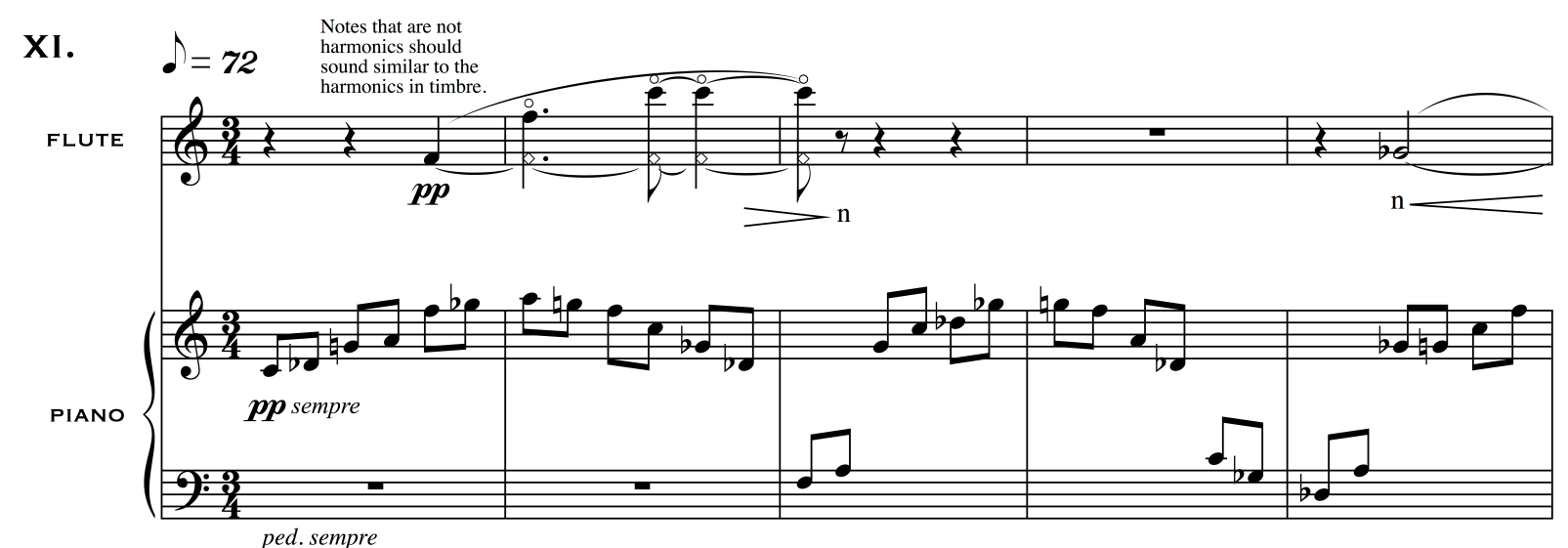

Figure 57

However, harmonics also follow the rules for just intonation, meaning that a harmonic producing the third of its fundamental chord will be flat, while one resulting in the fifth will be sharp. Therefore, it is "necessary to audiate what the piano gives you pitch wise, and match it." ${ }^{271}$ At least one rehearsal should take place on the piano to be used in performance to check the intonation on harmonics where the flute and piano are in unison. ${ }^{272}$ Some of the following alternate fingerings may also help with pitch, depending on the tendencies of the instrument:

- F5: press only the key ring of the F key ${ }^{273}$

- G-flat5: press only the ring key of the $\mathrm{F} \#^{274}$

- $\quad$ F6: add the right hand $\mathrm{C} \# \mathrm{key}^{275}$

${ }^{270}$ Dick, The Other Flute, 9.

${ }^{271}$ Goodman, interview by author.

${ }^{272}$ Ceccomori, interview by author.

${ }^{273}$ Goodman, interview by author.

${ }^{274}$ Ibid.

${ }^{275}$ Almarza, interview by author. 
As the harmonics rise and fall in pitch, the tongue may be moved higher to allow the higher frequencies to resonant, and lower in the mouth to produce the lower partials. ${ }^{276}$ As previously mentioned in reference to the fifth movement of this composition, preparation of this movement will benefit from the incorporation of harmonic exercises into the flutist's daily routine. ${ }^{277}$

Beginning in measures 7, 13, 20, and 22, Williams writes a gesture using accelerating and decelerating articulation with a "very breathy" 278 timbre (see measure 7 in figure 58).

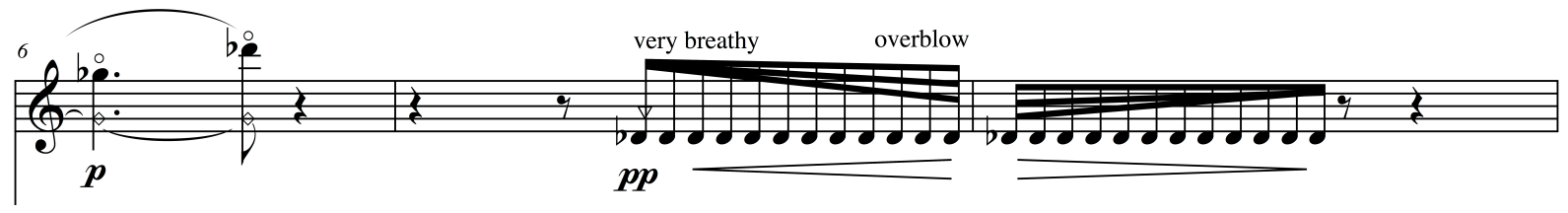

Figure 58

The flutist should also "overblow" 279 as maximum speed is reached. The flutist can consider beginning each gesture by single tonguing, then progressing to double tonguing and back again as the articulation speeds and slows. ${ }^{280}$ Raising, and then lowering, the direction of the airstream as the figure changes speed and moves from pianissimo to the peak of the crescendo and back again will move the pitches up and down the harmonic series, and accomplish the rise and fall that Williams intends. ${ }^{281}$ Goodman recommends careful pacing throughout these figures, with each subsequent statement expanding farther than the one before. She suggests that measures 7 and 8 should contain the narrowest range, the distance in measures 13 and 14 is slightly wider, culminating in the widest interval in measures 20 and 21 before narrowing again in measure 22

${ }^{276}$ Goodman, interview by author.

${ }^{277}$ Almarza, interview by author.

${ }_{278}^{278}$ Williams, First Lines, 20.

${ }^{279}$ Ibid.

${ }^{280}$ Goodman, interview by author.

${ }^{281}$ Almarza, interview by author. 
to add to the drama of this compositional element. ${ }^{282}$ Throughout the movement, vibrato should be judiciously applied, and eliminated in the softer moments, especially in measure $28 .^{283}$

Minimal vibrato may be used throughout.

${ }^{282}$ Goodman, interview by author.

${ }^{283}$ Almarza, interview by author. 


\section{CONCLUSION}

In the $20^{\text {th }}$ century, composers Igor Stravinsky, Gyorgi Ligeti, and Edgar Varèse explored new ways to utilize rhythm and timbre, expanding the limits of musical language. The opening bassoon solo of Stravinsky's Rite of Spring utilized a rarely explored color of the instrument, and is still one of the most compelling and expressive uses of the instrument in the orchestral repertoire. The Hungarian dances of Ligeti’s Musica Ricercata use rhythm to evoke a spirit of light playfulness that remains fresh over 50 years after their premiere. Varèse was one of the first composers to use extended techniques for the flute, including key clicks in Density 21.5 in 1936, a work that is also one of the earliest to incorporate the extreme high range of the instrument with a total of 9 uses of D7. These composers are Williams' primary compositional influences, ${ }^{284}$ and their legacy can be heard in her careful exploitation of timbral effects, the complexity of her rhythmic writing, and the economy with which she explores musical material. When Williams utilizes these compositional elements, it is only ever to serve as a means for musical expression. It is the author's opinion that this artistic integrity will insure that First Lines becomes a significant addition to flute repertoire.

Williams' music is very challenging, but the writing is economical and effective, and the specificity and clarity of her writing style is respected in the contemporary music community. The fact that Williams' music is often programmatic allows an entry point for audience members who may not have much experience listening to contemporary music - individuals who have little familiarity with music of this century often enjoy her music as much as the most seasoned and particular musicians.

${ }^{284}$ Williams, interview by author, 24 January 2014. 
Williams has repeatedly communicated that she is a pragmatist. Her experience as a working performer makes her sensitive to the point of view of the performer. While some of the things she asks of the flutist and pianist in First Lines may be difficult to coordinate initially, all aspects of the piece are manageable by advanced performers. This is a piece that could be included in the curriculum for an advanced undergraduate student.

It has come to be expected that every flutist will learn a piece including extended techniques, and works by Robert Dick, Ian Clarke, and Robert Aitken are often included on degree recitals. Certain works possess more artistic merit than others, as composers occasionally focus more on extended techniques themselves than on artistic expression. Williams is not one of these composers. Kevin Noe, Artistic Director of Pittsburgh New Music Ensemble, said the following of First Lines: "Williams not only picked the right atmosphere for each movement, but she also completed that 'last' step that so many composers now permit themselves to take with less seriousness: she actually chose the right notes. ${ }^{285}$ As explored in this document, the specificity with which Williams organizes rhythm, timbre, and different relationships between the two instruments serve only the voice of the poets and the composer, and for that reason it is nothing short of a masterpiece.

${ }^{285}$ Kevin Noe, E-mail message to the author, 7 December 2014. 


\section{BIBLIOGRAPHY}

Almarza, Alberto. Interview by author. In person, October 10, 2010.

America. Performed by Andrea Ceccomori and Elitza Harbova. 2008. Rome, Italy: DVM Records, 2008. Compact disc.

"Biographical Note." Guide to the Patricia Goedicke and Leonard Wallace Robinson Papers 1910-2006, bulk 1931-2006, Northwest Digital Archives. Accessed January 27, 2011. http://nwda-db.wsulibs.wsu.edu/ark:/80444/xv43658.

"Biography." Amy Williams Music. Accessed November 8, 2014. http://amywilliamsmusic.com/biography/.

"Biography." Andrea Ceccomori. Accessed November 7, 2014. http://www.ceccomori.it/contenuti2.php/lingua/eng/pagina/biografia.

Ceccomori, Andrea. Flute Today: A Short Practical Method for Contemporary Flute Players. Madrid: Dasi Flautas, 2009.

Ceccomori, Andrea. Interview by author. Phone, March 3, 2010.

Chin, Marilyn. "How I Got that Name.” Poets. Accessed August 16, 2012. http://www.poets.org/viewmedia.php/prmMID/15631.

Chin, Marilyn. Rhapsody in Plain Yellow: Poems. New York: W.W. Norton, 2002.

Chua, C. L. "Rhapsody in Plain Yellow," Magill's Literary Annual June (2003). Accessed August 16, 2012. http://web.ebscohost.com.

"Colleen J. McElroy," The Poetry Foundation. Accessed September 23, 2011. http://www.poetryfoundation.org/bio/colleen-j-mcelroy.

Derricotte, Toi. Captivity. Pittsburgh: University of Pittsburgh, 1989.

Derricotte, Toi. The Black Notebooks: An Interior Journey. New York: W.W. Norton, 1997.

Dick, Robert. Lookout! New York: Modern Flutist, 1989.

Dick, Robert. The Other Flute: A Performance Manual of Contemporary Techniques, Second Edition. St. Louis: Multiple Breath Music, 1989.

Dick, Robert. Tone Development Through Extended Techniques. revised edition. St. Louis: Multiple Breath Music, 1986. 
Eastman, John. "Poet Toi Derricotte," Black and White: Interviews, Essays, and Reports (1998). Accessed September 18, 2010. http://blackandwhiteprogram.com/interview/poet-toiderricotte.

Goedicke, Patricia. Listen, Love. Danville: Barnwood, 1986.

Goodman, Lindsey. Interview by author. Skype, January 4, 2014.

Green, Anne-Elizabeth. "Marilyn Chin," in Contemporary Women Authors, ed. Pamela Shelton. Detroit, MI: St. James Press, 1998.

Hill, James L. "Out of St. Louie Into The World Unbound: an Interview with Colleen J. McElroy," African American Review 42, no. 2 (2008). Accessed September 23, 2011. http://go.galegroup.com/ps.i.do?\&id=GALE\%7CA199599245\&v+2.1\&u=ein_remote $\& \mathrm{it}=\mathrm{r} \& \mathrm{p}=\mathrm{LitRC} \& \mathrm{sw}=\mathrm{w}$.

"History." Alberto Almarza Flute. Accessed November 7, 2014. http://www.albertoalmarzaflute.com/biography/.

"Honami." Alberto Almarza Flute. Accessed November 7, 2014. http://www.albertoalmarzaflute.com/listen/.

“Horizons: Ancient Flutes.” WQED. Accessed November 7, 2014. http://www.wqed.org/tv/watch/?sid=488\&series $=2$.

Horn, Robin Mason. “Extended Techniques Resource Page.” Larry Krantz Flute Pages. Accessed November 6, 2014. http://www.larrykrantz.com/et/et.htm\#Instructional.

"Lectures." Alberto Almarza Flute. Accessed November 7, 2014. http://www.albertoalmarzaflute.com/lectures/.

"Marilyn Chin." The Poetry Foundation. Accessed November 10, 2011. http://www.poetryfoundation.org/archive/poet.html?id=81896.

McElroy, Colleen J. Travelling Music. Ashland: Story Line, 1998.

Moyse, Marcel. De la Sonorité: Art et Technique. Paris: Alphonse Leduc, 2000.

Noe, Kevin. E-mail message to the author, 7 December 2014.

"Patricia Goedicke." Contemporary Poets, Literature Resource Center. Accessed January 28, 2011. http://go.galegroup.com.www.libproxy.wvu.edu/ps/i.do?\&id=GALE\%7CK $1660001035 \& v=2.1 \& u=\operatorname{morg} 77564 \& i t=r \& p=L i t R C \& s w=w /$.

Pellerite, James. A Modern Guide to Fingerings for the Flute, Second Edition. Van Nuys: Alfred, 1964. 
Polukhina, Valentina. "Excerpts from an Interview with Olga Sedakova," Modern Poetry in Translation. May (1994). Accessed September 16, 2011.

http://www.poetrymagazines.org.uk/magazine/record.asp?id=13272.

Polukhina, Valentina. "Olga Sedakova: Russian Poets of the Soviet Era," Russian Poets of the Soviet Era 359 (2011). Accessed September 16, 2011. http:/go.galegroup.com/ ps $/$ i.do?\&id=GALE\%7CH1200014175\&v=2.1\&u=ein_remote\&it=r\&p=LitRC\&sw=w.

“Press.” Lindsey Goodman, Flute. Accessed November 8, 2014. http://lindseygoodman.com/press.html.

Ray, David. "Patricia Goedicke," Contemporary Women Poets, ed. Pamela Shelton. Detroit : St. James, 1997.

"Recordings.” Alberto Almarza Flute. Accessed November 7, 2014. http://www.albertoalmarzaflute.com/recordings/.

Sedakova, Olga. The Silk of Time: Bilingual Selected Poems. Keele: Keele University Press, 1995.

Smith, Martha and Lea Sparks. "Toi Derricotte, Novel Guide (2010). Accessed September 12, 2010. http://www.novelguide.com/a/discover/aww_01/aww_01_0035.html.

Taffanel, Paul and Philippe Gaubert. Seventeen Big Daily Exercises for the Flute. Paris: Alphonse Leduc, 1958.

“The Consummate Flutist.” CMU Flute Forum. Accessed November 7, 2014. http://www.cmufluteforum.com/.

"Toi Derricotte: Biography." The Poetry Foundation. Accessed September 18, 2010. http://www.poetryfoundation.org/archive/poet.html?id=81170\#bibliography.

Williams, Amy. “Amy Williams, Ph.D.” Academic Curriculum Vitae, Pittsburgh, 2014.

Williams Amy. E-mail message to the author, November 7, 2014.

Williams, Amy. First Lines. Pittsburgh: Self-published, 2006.

Williams, Amy. Interview by author. In person, February 3, 2010.

Williams, Amy. Interview by author. In person, January 24, 2014. 


\section{APPENDIX I: The Poems}

I. For the Dishwasher at Boothman's by Toi Derricotte

I sit in front of him

and look him in the eye.

Pastrami on rye.

So accustomed to being invisible,

he startles, as if a door

opened and revealed his face.

His smile says, you should know better, and he nods his head to the right

like a low angel would nod toward God.

His face is warped

around a center crack, as if

two pains were seamed

together at his birth.

His face would break

his mother's heart.

I read down the left side.

I read down the right. ${ }^{286}$

${ }^{286}$ Derricotte, Captivity, 58. 
When the air is thin with frost

I blow rings of ice smoke

as I did when I was young and imagined myself grown and never answering to anyone. From smoke rings to pots that became helmets and tanks, I play-acted a world where color held no name and eyes were tears holding light.

Without knowing the contours of earth, any rock can become mountain, and puddles vast oceans of many-legged beasts. None of this is new. All children are urged to wander through the screen of what is real before they are pushed into the serious matter of living where they lose

the surprise of believing.

We become adults with only a toehold on fantasy, like ghost light from a torn retina vanishing in the corner of the eye where, half blind, we learn when to turn a phrase or bend a letter until $o$ becomes $e$ or 3 evolves into 8 and less simple digits.

No easy idiot graffiti of girl into gril, but loan into god and home into bog. One blink and a sign that reads:

Warning: Truck Makes Wide Turns can be misread as Caution: This Woman Breaks for Every Turn and everything is possible. ${ }^{287}$

${ }^{287}$ McElroy, Travelling Music, 87. 
Sister Maureen Murphy, a teaching nun in the Rochester-based Sisters of St. Joseph, was arraigned in June 1976, on a charge of first-degree manslaughter in the death of her newborn son. In 1977, she was tried and declared not guilty.

"I know it matters if I'm convicted, but I've already imprisoned myself in my mind and heart. I'm imprisoned because I can't escape from my thoughts. I want to know if I harmed the child. I know I must have, because I was the only one there."

--From a conversation with psychiatrist William Liberston on 20 May 1976.

\section{1}

i enter.

woman leads me in, red tiles and clerestory windows, the sun bleeds in like beets;

"my daughter," she says not kindly or unkindly, but as if her tongue were tied, her smile a deformity, "sell your lover's heart for Christ."

we eat the blood-soaked stone, dislodge thigh, crack dry skin in our teeth, as if the grit of innocence must match the muscle in our jaws.

my skin grows black.

i burn.

my eyes pale like lepers.

i wear goat fur, stink of sin

in the middle of their kindness.

under my hood, i do not pry as they think my eyes turn pink with rage 
clear as the nucleus of a germ.

these are the works of God:

the miracle ignites Him in my bones.

3

the children in my care

with wisp-thin wings

like butterflies of glass

fly to the brown

floor of my shuttered room, their music in my book

like a rush of wet sweet air.

i come down to meet them,

breathing in the iron corset, head

spinning loose and fragile,

floats like an angel in a starched white pinafore.

i rush with arms

to shut the gap

fit airless bodies

in this chewed

curve of my spine.

a man comes in the bar,

this is a dream, it seems

to be a dream

how did $i$ get

in this seaport town, how

did i trawl

this black lobster

with my own claw

how did i latch

him by the throat

and hand him my life?

i drink a beer, the glass

slick in my hand as sea, the room smells of fog; myself in a cotton dress, 
the table top unwashed,

blurry as a drunk man's face

(where are my sisters

like bells they are

shivering in that dark tower)

he follows me,

a presence in the bushes

like an image in a black mirror

the moon breaks. his face

is ashes in the crowns of trees.

5

the air hums at night

the wings of bees

beg for entrance at my ears

return to the familiar nest

it is spring

this year there is a heart

at its center

red with thorns

He grinds me muscle thick

i cannot shut the singing out

\section{6}

one night i place my ear

against the wall

sometimes

i hear Him

out there

sometimes

I feel Him

shake the floor

lonely as a devil

drive through darkness 


in harness
not left
not right
for fear

His eye

lidless and white

watches

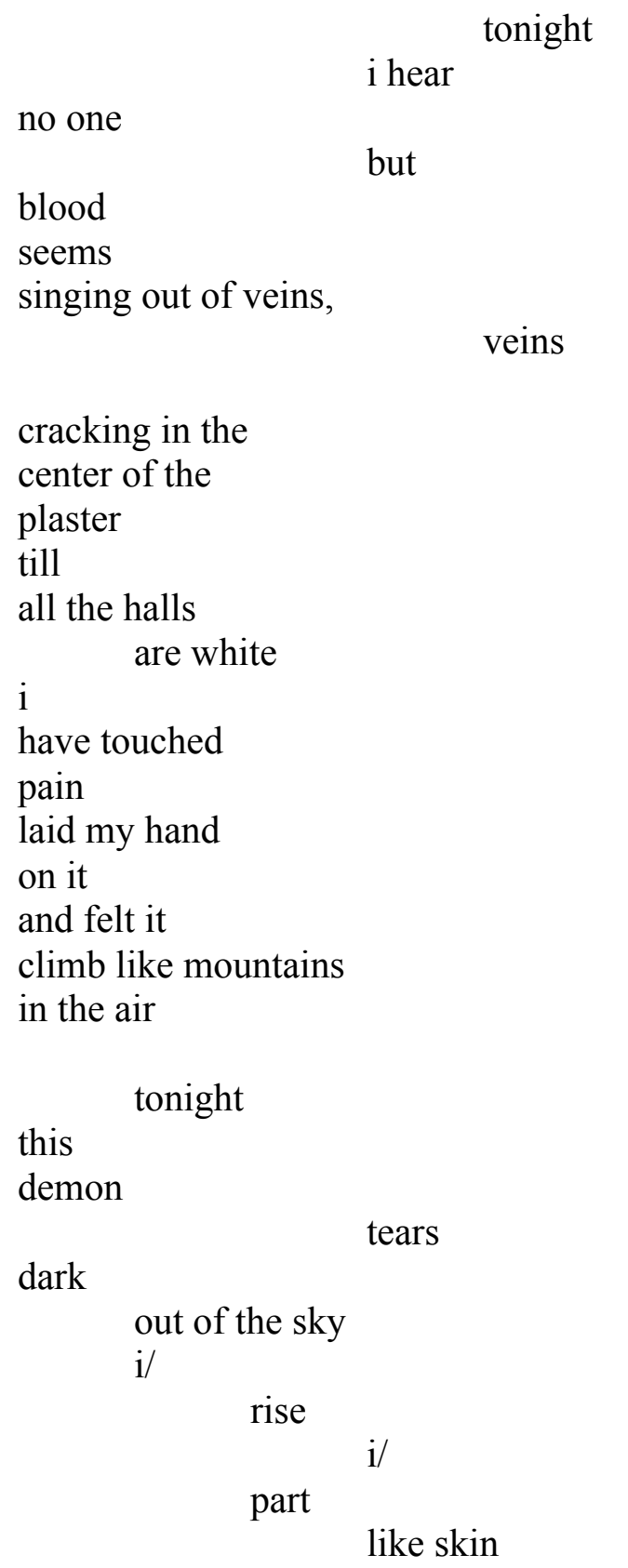


over

His goat heart

the child is dead

they bring him in a white boat

to my bed

like moses

like the jew-child

i place him in the reeds

thickly hidden

in the salamander green

and the brown bark

my stocking is around his neck

$i$ am the maiden in the window

who watched him through the first

bright

ball of air

triumphant

as a god

god/

i am

mother

will take my place ${ }^{288}$ God

${ }^{288}$ Derricotte, Captivity, 41-47. 


\section{Horseyear by Marilyn Chin}

In the margins you roam free

As far as the paddock will take you

The poet has lost her chariot

Stumbling for the orchard in twilight

Your Toyota's stuck in the mud

Push, push 100 pound girl

Already you're a millennium late

Your forelock soaked in rain

Who will take that bit?

Your mouth is hard or tender?

Your flesh is deep in your sheath

Who is holding the tether?

The bones of the dead are fragrant

They breathe in lush desire

Joss ticks and peonies ablaze

To secure their eternal fame

When young you learned the flute

When old you taught the zither

Forty, you wrote for love

Seventy, you yearn for God

The eyes of Kuanyin can't lie

A tear shall fall from heaven

She brought us hear on her back

America, our legs are broken

Hack a river in his thigh

Augur from the skull of our beloved

Kiss his bract of hemlock

Hardened in river clay

His soul has been dead for years

His body's flexion bronze

A midvein pulses blue

The killing floor glistens

Bosnia, a headless would

Los Angeles, a blistering glans

Rwanda, a whither of blood 
The killing floor glistens

Our yokes and goads are broken

Wheel locks in idle wind

We love you from a distant wasteland

Our prayer the blackdrop of sky

We sit alone with our porridge

Whose name is Budget Gourmet

We've missed our chance in love

$\mathrm{O}$ brief and fallen Orchid

Beautiful, cut sliced moon

O muse of X-Acto knife and rain

Cocked between dream and window frame

$\mathrm{O}$ pale and loitering suitor

Climb the liana of the mansion

Begging bowl in hand

We hunger for love and fame

A piece of the world at sunset

Our pupils will avenge our deaths

Our rivals will fall to disgrace

Jade and gold in their mouths

Plundered over and over

Our hair will grown after death

our poetry, moss eaten

Never will we feel fulfilled

Never to reclaim our name ${ }^{289}$

${ }^{289}$ Chin, Rhapsody in Plain Yellow, 92-95. 
Family Restaurant(\#2) by Marilyn Chin

The old neon flickers and hums.

The grandmother turns it off.

The boy empties the last of the trash, Eager to return to the prom.

The grandmother gestures him back, Fan loy, fan loy, waving both arms.

He curses Goddam old hag,

Rolls up his tux sleeves gingerly,

Sorts out the bones from the glass. ${ }^{290}$

${ }^{290}$ Chin, Rhapsody in Plain Yellow, 77. 


\section{That Half Is Almost Gone by Marilyn Chin}

That half is almost gone,

$$
\text { the Chinese half, }
$$

the fair side of a peach,

darkened by the knife of time,

fades like a cruel sun.

In my thirtieth year

I wrote a letter to my mother.

I had forgotten the character

the radical "heart."

for "love." I remember vaguely

The ancestors won't fail to remind you

the vital and vestigial organs

where the emotions come from.

But the rest if fading.

A slash dissects in midair,

$a i, a i, a i, a i$,

more of a cry than a sigh

(and no help from the phonesticist).

You are a Chinese!

You are a Chinese?

My mother was adamant.

My mother less convinced.

Are you not Chinese?

My mother now accepting.

As a cataract clouds her vision,

and her third daughter marries

a Protestant West Virginian

who is "very handsome and very kind."

The mystery is still unsolved------

the landscape looms

over man. And the gaffer-hatted fishmonger-----

And the maiden behind the curtain

sings to his cormorant.

is somebody's courtesan.

Or, merely Rose Wong's aging daughter

Pondering the blue void.

You are a Chinese-----said my mother

who once walked the fields of her dead----- 
Today, on the $36^{\text {th }}$ anniversary of my birth,

I have problems now

even with the salutation. ${ }^{291}$

${ }^{291}$ Chin, Rhapsody in Plain Yellow, 17-19. 


\section{Hospital in Oregon by Marilyn Chin}

Shhh, my grandmother is sleeping,

They doped her up with morphine for her last hours.

Her eyes are black and vacant like a deer's.

She says she hears my grandfather calling.

A deerfly enters through a tear in the screen, Must've escaped from those there sickly Douglas firs.

Flits from ankle to elbow, then lands on her ear.

Together, they listen to the ancient valley. ${ }^{292}$

${ }^{292}$ Chin, Rhapsody in Plain Yellow, 41. 
VII. The Athlete by Patricia Goedicke

Sometimes, when the sun stands up

Right out of the ground

There's no doubt about it,

You're talking to a young man

Sudden as a haystack or a geyser.

Spouting a hatful of gold coins

Some kind of supernatural

Athletic energy fills the air

And you fall back

In astonishment, $\mathrm{O}$

Where is misery, irony, despair?

Brassy, wearing the blue sky

Perched on his head like a bowler

He smiles like James Cagney playing George M. Cohan

Until you can't help staring:

Houses jump for joy,

Trees shine, end the birds with them,

Something takes your breath away

These rare days when he winks

As if it were all true,

As if there were some hope

After him even old hearts

Bounce in their beds like children,

Like a heavenly beachball he rolls on

Right through town like a trumpet. ${ }^{293}$

${ }^{293}$ Goedicke, Listen, Love, 33. 
VIII. Chaplinesque (2) by Patricia Goedicke

Gestures made against snow:

The fling

And scatter of birdseed onto burned grass.

At every feeding station the arch

Of each age is ridiculous to the next.

The trajectory of a slingshot.

Man hurls his aircraft into the night sky:

Frail scarves, rhinestones

Wink against the stars

While you tiptoe on the ice, neat bottomed, Stringy against cold bushes.

With one eye on your audience you advance As if you were on stage, absurd

But perfect, teetering on one foot, mocking A ballet dancer busy at his grace.

Birds dash themselves across the landscape

But out there at the feeder like a football player Flipping your small hands

Old man you are my old man:

Every play you make is a grandstand. ${ }^{294}$

${ }^{294}$ Goedicke, Listen, Love, 38. 
IX. The Princes Of Heaven by Patricia Goedicke

First it is only the sense of sunlight

Creeping up over the dunes

Darkness is beginning to pale

Imperceptible sounds

In every corner of the house there are shiftings

Minute, barely distinguishable

The delicate slow tide rises

Out on the long marshes

Something is running through the tall grass

Crinkling it with excitement

Inside it is as if they were moving furniture

The heavy velvet of the couch

Blunders over to the window

The crisp curtains are beginning to breathe

Fronds of your hair sweep

Back and forth along the floor

Out on the porch of your thighs

Sandpipers flicker, with their little feet

From one fiber to the next

The flat wooden planks are beginning to swell

And now the seagulls are impatient, mewing And flapping their wide wings,

Turning your quiet abdomen into a loud

Fourth of July day crowd

With flags waving, people

Jostling each other in the street

Your breasts are beginning to ache,

They are turning into Scylla and Charybdis

But softer, with hearts of butter, Nipples of pure cream 
Your teeth open and close like the jaws

Of a ravenous whale but gentle,

Rolling in its own sweet wake

The inner and outer lips are turning purple

Stretching themselves like a child sucking

The agitated motion of the round pilings

On either side of the dock increases

Waves slap back and forth

Both buttocks are jerking

The white galaxies of night

Inhabit the day, in a trance

The orange prow of the ship appears

Over the horizon it shoves its way

Across the smooth sheets

Shooting stars and colored streamers

And twenty-one gun salutes

All the princes of heaven come

Leaping onto the land,

Exploding together into dawn

The earth shakes itself to pieces,

In the hot arms of the sun

The sides of the waiting wharf heave

Up to the sky and then down. ${ }^{295}$

${ }^{295}$ Goedicke, Listen, Love, 51-52. 
Is that only the windows creaking, Maria, the wounded panes in them trembling?

If this is no garden

then let me return

to the silence where things are invented.

If this is no garden, where the windows are trembling because this darkness is denser than any, if this isn't the garden of which it is written that children sit hungry next to the apples forgetting the fruit they have bitten,

where there's not one light, even, but breathing is darker, and the medicine of night brings more hope; I don't know the name of my illness, Maria. My garden stands taller than I do.

\section{Translated by Catriona Kelly ${ }^{296}$}

\footnotetext{
${ }^{296}$ Sedakova, The Silk of Time, 23.
} 
1

I was surprised by

how calm the waters were,

how familiar the sky was

and how slowly the junk sailed past the rocky banks.

My home country! my heart screamed when I saw

the willows:

those willows in China are the same,

washing clean their oval shapes at will,

for it is only our generosity

that will meet us beyond the grave.

2

The pond speaks:

if I had hands and voice, how I would love and cherish you.

The people, you know, are greedy and always sick and tear others' clothes

for bandages for themselves.

I need nothing:

tenderness means getting healthy again.

Like a tame wild animal

I would put my hands on your lap

and descend from above

as the sky, voice-like.

3

They don't fall, though they fall,

my old trees dip into the water

but do not get their long sleeves wet-

pagodas, roads!

How often have we seen each other,

but each time like the first

my breathless heart races

with a completely empty bag

along the trunk, over the hills and gullies of branches

to the long, broad eyes of the churches

to the mirror on the altar

on the green floor.

Have we not wandered enough

to finally turn off

onto the only, dearest,

invisible road, 
that offends no one?

The hat that makes one invisible.

The clothes of godliness, the clothes

fall from the eyes and don't fall,

dip into the water and don't get wet...

Trees: for you alone the word 'I love' is worthy.

4

There, on the hill

on whose lap

where the last hut stands

and no one ever ventures higher;

whose forehead cannot be seen behind the clouds

and one can't tell if it's glum or happy -

someone comes and doesn't come, to be and not to:

the size of a swallow's eye,

of a crumb of dry bread,

of a ladder on a butterfly's wings,

of a ladder thrown down from the sky,

of a ladder, which no one wants to climb,

tinier than anything a bee can see and than the word is.

5

Do you know

the dwarf pines, the weeping willows?

The untied boat

does not prod the bank for long.

and neither joy

of that which was

nor pity:

we're all here today, but who knows about tomorrow?

Nor reason,

only spirits are without reproach,

modest, fearless and kind-hearted -

nothing will stop

the simple rapture

setting like the sun.

The untied boat

floats without a thought,

the broken branch

will grow again - but not under these skies.

6

I shall only see

the pilgrim in his bright white raiment, what can we do, where can we go? 
I shall only see the white raiment, the old shoulders.

It would be better if my eyes were stone

and my heart water!

I shall only see

what happens to a man -

I would walk after him in tears,

I would walk as far as he did,

with an unhurried pace.

7

The boat flies

in the lower wet, blue sky.

The sky darkens swiftly

and looks with eyes of another sapphire.

Did you know? Nobody every trusted me,

like a child dying of his own boldness

says to another child - 'Yes

and they bury something under the third pine...'

So I say:

nobody ever trusted me

and you won't trust me either,

but don't tell anyone.

As the boat flies, the sun shines

and the sky's joy plays in the sapphire.

8

The roofs are raised at the edges

like eyebrows in surprise.

What do you mean? Really? I'm happy to the

bottom of my heart!

From these terraces everything

dear to man

can be seen eternally:

the dry banks,

the silver-yellow rivers,

the scrawled letter of the bushes -

a love note.

Two passers-by bow

low to each other on the pontoon bridge

and a swallow brings the height

in on a teaspoon.

Heart drops, healing potion.

However, no one is sick in China,

for the sky itself is an expert

at acupuncture.

9 
Unhappy

is the person who thinks of tomorrow while talking with

his guest.

Unhappy

is the person who does something and thinks that

he does it,

and not that the air and sunlight rule him,

like a brush, a butterfly, a bee,

he who plays a chord and thinks

of what comes next -

unhappy, timid and stingy.

Even more more unhappy

is the person who does not forgive:

insane, he doesn't know that the stork comes out

tame from the bushes,

that the golden ball

will soar of its own accord

into the dear sky over the dear earth.

10

Great is the artist who knows no debt

except for his debt to the brush's play

and his brush enters into the heart of mountains,

enters into the happiness of leaves

with one stroke with one gentleness

rapture, confusion,

with one gesture he enters into immortality

and immortality plays with him.

But he whom the spirit has deserted,

from whom the light has been taken,

who, for the tenth time in a troubled place

searches for the pure spring-water,

which fell from the hand of miracles but will not say:

'These are false miracles!':

before this person the skies bow

in reverence.

11

With tenderness and depth -

for only tenderness is deep,

only depth possesses tenderness -

I recognize in a thousand faces

who has seen it,

whom it was looked at,

the tender depth

and the deep tenderness 
that dwells in stone and glass objects.

So let the warm lamp of the west

give light,

and the street lamp, the moth trap.

Talk to our homely light,

sun of tenderness and depth

sun deserting the earth

the first and the last sun.

12

Perhaps you are the precious ring of the spirit

the stone of blue water,

a voice talking dully

about the terraced gardens.

But look, the winged chariot flies, lamenting,

the wind, the sand, the banks,

the empty ocean.

It's impossible to say farewell, and there's nowhere to say farewell to you.

O person as simple

as salt in sea water,

he is not like speech, he is not like a face, he is not

like a word,

only salt with iodine and surf

lamenting to itself

with no one to turn to:

perhaps you are the ring of the spirit

the stone of blue water,

a voice talking dully

about fabled gardens.

13

Will we really part,

part like everyone else?

Knowing something

about passion swifter than the end,

about the world smaller than a penny -

let they who need it take it -

knowing that

this shell has no pearls,

that there is not a single match, candle or lampion

only the fire of rapture,

knowing from where

sonorousness and luminescence come. 
Will we really part, like simple ignoramuses?

No less than the willow growing by the waterside, no less than the water follows the magnet of the star, than drunk Li Po looking into the wine, yellow as the moon and than a stone sinks to the bottom: loving to be together... Will we really part like simple misers and boors.

\section{4}

Flute answers flute, not a bone or wooden one, but the one which mountains hold in their caves and cracks. Strings answer strings and word answers word.

And my heart's wish answers

the swiftly ascending evening star: evening star you bring out thousands of stars and with a thousand wishes my heart burns with a myriad of wishes about one and the same thing: wake and look at me, my inspired friend, watch the sparkle of the night...

\section{5}

They say, they have gone on the white road and the cold, starry sky, they have gone and we will go too one day: stepping across the water from stone to stone, stepping across the parting from planet to planet like a singer's voice from note to note. There everyone will definitely meet, they say, whitened by the Milky Way. I confess that so many times my heart has approached the forbidden threshold, how many times has it beat fast promising something to someone unknown: no one is seeking me, no one is worried about me, no one will ask me to stay with them. Oh, not from the world's grief, it's so wonderful behind the world's door, 
but because I don't want,

don't want my sins,

because it is time to go

and ask forgiveness for everything -

you see, no one can survive without this bread of shining.

It is time to go there

where everything is compassion.

\section{6}

You know that I love you so much

that if time comes

and leads me away

it will not be able to take me away -

how can one forget the fire?

How can one forget

that happiness wants to live

and grief wants to disappear?

You know that I love you so much

that I will not distinguish from this,

the sighing of the wind,

the rustle of branches,

the life of the rain,

the road that is like the candle

and what the alien darkness mutters

about the mind striking like a match into flame,

and even the unfortunate sound

of a frail butterfly striking the window pane.

\section{7}

When we decide to set out,

not knowing what awaits us,

on the empty ship of inspiration,

on a badly constructed raft,

on a scaly wing,

on a boat without oarsmen,

imagining the best

and worst ends,

and searching for nothing inside:

there in exchange for everything

they cast the oracle bones

on the Book of Changes.

Who created the wasteland of waters?

Who discovered that there is war above?

Who ordered

that gardens should grow

from fiery seeds? 
Like the nightingale

better to die

than [sic] not sing what has to be sung,

than [sic] not to write on the silk

of times what a whole people cannot write.

Inspiration,

when you whistle your tune,

when your waters rise

between dry land and our souls -

if only the whirlwind knew,

and you too, empty smooth waters,

how much I wish for absolution and to kiss somebody's feet.

18

Let us praise our earth,

let us give praise to the moon on the water,

that which is with no one and with everyone,

everywhere and nowhere -

the size of a swallow's eye

of a crumb of dry bread,

of a ladder on a butterfly's wings,

of a ladder thrown down from the sky -

not only disaster and pity,

the bridle of my heart:

but because the wonderful

water smiled.

Let us praise the bathing

of priceless dark branches

in the living panes of glass

and all the sleepless spirits

in every seed of the earth

and that rewards exist

that ward of evil

and that the glory of the earth

is like the gardener and the garden.

Translated by Richard McKane 297

${ }^{297}$ Sedakova, The Silk of Time, 73-91. 


\section{APPENDIX II: Transcript of an Interview with Amy Williams}

On January 24, 2014, the author interviewed Amy Williams on topics concerning the composer's personal history, as it relates to her professional life, professional history and the process of composing First Lines, the resultant composition, and performance suggestions for flutists and pianists.

Pamela Murchison (PM): How did the First Lines commission come about?

Amy Williams (AW): It was through the composer Orlando Garcia, who teaches at Florida International University. I've known Orlando for many years (he'd studied at the University of Buffalo) and did his doctorate there with Morton Feldman. When I grew up my father was on the faculty there, so Orlando is someone my family has known. I've been down to Miami quite a few times to play in festivals and concert series. We reconnected as adults. So Orlando was in touch with this flutist, Andrea Ceccomori, who wanted to do a CD of new American music, and asked for Orlando's advice for other composers to work with. First Lines was originally for a different pianist, but situations change, so we worked with Elitza Harbova.

PM: Have you actually performed First Lines?

AW: I have. I played it with one of my former students, Kerrith Livengood. Kerrith and I did it a couple of times.

PM: Have you coached other flutists?

AW: I heard you play it. I worked with Lindsey Goodman right after I completed the piece. I wrote it in May, she was here in July, had some of these multiphonic fingerings and extended techniques I wanted to try out on her, we worked on that together and then I finished the score. PM: She was your consultant? 
AW: Yes, it's always helpful to have someone to work with closely. A group of students did it in California, which was kind of interesting. They each took a few movements, three or four of them, they went around in a circle playing movements, with one pianist. I've worked with Erin Lesser, who plays with Wet Ink Ensemble, who has played the piece. It's been done quite a few times.

PM: Who were your principal composition teachers?

AW: I went into the family business. The first thing I ever wrote was my senior class song in high school. Then I went to Bennington College for my undergraduate degree, a liberal arts college, I took the Music I class, and my teacher then was Lou Calabro. One of the first assignments was to write a solo clarinet piece. I had no idea how to do that. I did it and thought I was very fancy for writing a piece in 5/4. From there I continued composing more and more, and in fact, stopped playing flute at that time. I was also a pianist and getting really into composition and I couldn't really balance both. My first year there I took piano and flute lessons, composition classes, but also French and Psychology so it was a lot to balance. I stopped playing the flute and concentrated more on piano and composition at the beginning of college. I still played in flute ensemble and did some other things like that for fun. I studied with Allen Shawn quite a bit for a couple of years while I was there. They were my main composition mentors in undergraduate.

Right after college I taught high school music for two years and continued to compose and play, working with some with teachers in Buffalo. Yvar Mikhashoff was a close family friend and pianist, and I was very interested in contemporary music and that was his specialty as a pianist. David Felder was on the composition faculty there, and I would take some occasional lessons with him as well. Then I went on a fellowship year to Denmark and studied composition with a younger composer, Sven Nielson, studied chamber music with a wonderful clarinetist Jens 
Schou and the pianist Rosalind Bevan. Mostly, it was a wonderful year to focus and play and write.

I wanted to come back to graduate school and one thing that I found that was difficult to do at other graduate schools was to get a degree in piano and a degree in composition, and I really wanted to be able to do both. I was able to do that in Buffalo. I received full funding and had two excellent teachers, so why look further than my own backyard? I started a Master's degree in piano and $\mathrm{PhD}$ in composition at the State University of Buffalo. I studied with David Felder most of the time, but a few semesters he was on sabbatical, so I studied with Nils Vigeland and Charles Wuorinen, each for a semester. I studied with Yvar Mikhashoff until his death in 1993. After that, I studied with Stephen Manes and went to Eastman and studied with Alan Feinberg. I formed my piano duo while I was at SUNY Buffalo, and the rest is history. Those are my main teachers.

PM: Outside the specific teachers, who are some of your compositional influences?

AW: That of course transforms over time. My influences just out of grad school are probably very different than influences in the moment. The persistent ones are Igor Stravinsky, Gyorgi Ligeti, and Edgar Varèse. Those are probably the three strongest. I'm also interested in composers like Sciarrino, and Grisey, and very interested in certain philosophies of more experimental composers from Charles Ives to John Cage. That influence isn't a direct influence, but the openness to what can be done in music is. The attitude is a very freeing thing to have. I do subscribe to some of those approaches to music making.

My very first flute teacher was Robert Dick. I had no idea how great it would be. I was in the third grade and had to pick a second instrument and I chose the flute because my sister was playing the cello and I didn't want to have to carry a large instrument on the bus, so I chose the 
flute. Not that I was particularly drawn to the instrument, it was sort of a practical consideration which has stayed with me for the rest of my life: I'm a little bit practical about things. I'll never forget, it was January, a cold day like this, the snow was blowing. I got my flute from school and my dad said "Okay. There's a guy who is here. He doesn't teach children, but he said he would be willing to try it out because he's a colleague of mine." My father asked, "When would you like to schedule your first lesson?" and I said "Right now!"

He called Robert, and we walked over in the blowing snow. Robert taught me how to put the flute together the right way, and taught me how to blow, and how to hold the flute. It was not very long before I was playing a lot. Honestly, if Robert had stayed in Buffalo I would be a flutist today. He was a phenomenal teacher, particularly for me. He sensed my slightly competitive side and would say something like, "Oh, I learned this piece when I was eight," so I would have it down the next week. He was a great teacher and I played everything - Telemann, Bach, and the typical Classical repertoire, etudes, and exercises, but also Chopsticks in multiphonics after a year of playing the flute. I would practice whistle tones. It was a comprehensive approach to playing the flute.

I played in the band and played in the state orchestra, and performed all the Classical stuff but I really loved the contemporary repertoire. Kids don't know, and they aren't critical of these things. Everything is new for them, so why be judgmental about how to play the flute? Robert was an amazing teacher, and I think I studied with him for two years. I loved the flute and played it constantly. He used to bring his graduate students to my lessons, probably not because that I was that phenomenal but so they could learn about teaching and pedagogical approaches. 
He went back to NY, and I had another teacher. She was great. After that, well, it's hard to follow when you start with Robert Dick. I lost interest in the flute after a little while, because having the right teacher is so essential.

PM: If you don't mind me asking, I'm curious about when you were studying with him, and how that lines up to when he was writing his book Tone Development through Extended Techniques. About when was that?

AW: It would have been in the mid 1970s; 1977, 1978, something like that. I was in the third grade. Robert was a Creative Associate at SUNY Buffalo for 2 years.

PM: Something I appreciate about playing your music is that you are a really active performer. How does that affect your style?

AW: I think it affects it a lot. I just had a lesson with a student who brought in a wonderful sound effect for the violin but with scraping a metal ruler on the strings. I said, "This is not practical. As a performer I would not do something that hurts my instrument. Unless you are supplying the string quartet with four instruments and four bows, this is not practical." I think there is a pragmatism that comes with being a performing musician. I am intrigued by issues of chamber music, from having long hours of rehearsals with chamber musicians. When I'm writing for a chamber group I'm thinking about the dynamic of interaction, what challenges there are rhythmically, in terms of ensemble issues. Writing for my piano duo, I think "What's challenging about the piano duo? What's particular to this medium and playing this medium that I can exploit compositionally?" I think about specific performers and what their strengths are at the instrument and what kinds of sounds I can exploit, the things they like, and that they do well. I try to keep the performer very much involved in the compositional process in my own mind. I'm always thinking about the performer, although sometimes more successfully than other 
times. I just finished an orchestra piece for the Pittsburgh Symphony Orchestra and as I'm printing out parts, I realize the bassoon parts are really boring, and I don't have much for the tuba to do, and I feel like apologizing to the player for not writing a more interesting part for them, but when you're dealing with so many parts it's hard to make every one of them interesting. I am always thinking about the performer. It gives me ideas, it takes me in new directions. I don't do much with electronics, part of that is because I need that human interaction, and that's where my ideas come from.

PM: Electronic music is a whole other can of worms.

AW: It's something with no limits, and I need those limits. I need to know how big the human hand is. I need to work within some confines.

PM: You've performed as a flutist and pianist. How does that compare to your writing for other instruments?

AW: It gives you something to strive for when you are writing for other instruments. I know all these fingerings so I need to think about the physicality of a clarinet, even if I can't produce a sound I can imagine the fingerings and the way the hands have to fit. You work with other musicians with the goal of understanding an instrument as well as you can. Writing for other instruments I always try to understand it as well as I can in terms of practicality. Writing for flute and piano feels very comfortable and familiar. It's a nice place to go, especially if I've been writing for strings and instruments I don't play for a long time. There's something very satisfying about it. There are always new things, and there are things you forget. Like you forget about that little pinky key at the bottom, or there are you want to push a little bit. You never want to get complacent, just because you know the instrument. It's challenging, when I write for piano, too. I know so much about what's been done with the piano, it seems like it's been 
exhausted, so to do something new, something fresh for the piano is challenging. I have to write this big solo piece, and I've been putting it off for years and year. What do I have to say?

Everything I do has a reference to something I already know. That can be challenging to know it so well that there is nothing new.

PM: Is performance something you advocate for your students?

AW: The students come in with such different experiences. I encourage them to work with instrumentalists as much as possible. I don't have a kind of music education approach where you have to be able to play a scale on every instrument. I think that only takes you so far. You need to work with a performer, and hear the sounds. If you can, get an instrument and feel what it's like to play it. Some of them come with a strong performance background, some without much. That will change with a generation of kids growing up on computers, maybe not being forced to take an instrument or with music education suffering in certain areas of this country. They each bring in very different experiences and we work with that.

PM: Two of the poets that you utilized in First Lines, Toi Derricote and Colleen McElroy, taught at University of Pittsburgh.

AW: I didn't know that about Colleen. Is that right?

PM: Yes. I came across that piece of information when I was researching the poets.

AW: Not only did I know that Toi was teaching at University of Pittsburgh, but we were at Bellagio Centre together. I met her, and then I found some of her books of poetry in the library. And of course I thought, "This is so serendipitous, I have to include some of her work in First Lines."

I didn't research them, in fact, I went through the library at Bellagio looking at poetry and pulling things out and kind of scanning them. I took about 10 or 12 books that interested me back 
to my room, and as I looked at them I saw they were all women poets. It wasn't that I was intending to only choose poems by women; it really just happened, but those were the books I was drawn to, those were the poets who words spoke to me. That also was kind of interesting to me.

PM: I would say you use timbre to represent the poetry. Was it the general work of the poets, poets in particular, or something that just captured you about the first lines of each poem?

AW: It was very much the first lines. It was being sucked in, drawn into a time, place, mood, atmosphere, a feeling and emotion immediately. There are brilliant poets where it takes a while to get into their poems. They are longer pieces and they're more epic, and the first line is ambiguous, it may be a brilliant poem but it didn't serve the function of this project. I really was scanning lines of poetry, just beginnings, until something gave me some kind of musical twinge. Something happened when I read that line, "Oooh, I can do something with that. I have an idea." It wasn't a chord or melody usually, it was a sound world, a sonic image that struck me right away. I had a few more that I didn't develop into pieces, they didn't go anywhere, but these 11, each one stood out.

PM: I find it fascinating how some of the poems, like the "Testimony of Sister Maureen", really work when you read the entire poem, while others are just a snapshot. It's not a long poem, it really just is the first line.

AW: I'm sure I read the whole poem, but in fact I didn't want to be too influenced by that. I really wanted to just focus on the beginning of it. So, rather than carrying these books with me to my studio, I just wrote down the first line. I didn't have the whole poem in front of me as I was working. I really just had the first line. Was I was influenced by reading the whole thing? It's 
possible, but mostly I was staring at those words, those 10 or 12 words and trying to keep it focused on that.

PM: When you first started, you were thinking of it in terms of a collection of miniatures?

AW: That was the first idea. I was looking for influence or inspiration. Then I thought, "Here's a poem, fine. What's interesting about it?" It's always a process. Then I had the idea of writing short pieces. It worked to use these short lines with short pieces. Why I wanted to write short pieces? Miniatures interest me. It can be challenging to write miniatures. They can need to be longer so you really have to limit your material. If you have too much material, the piece can feel incomplete, like it needs to go on. So to write something that really feels complete in a short amount of time is very challenging. You can't set up a situation where you need to develop an idea over time. The ideas need to be somewhat complete and do one thing or two things but that's it. That's been something I had wanted to do, to write a series of miniatures, and once I got these poems, it sort of clicked.

PM: What sort of piece did the commissioner specify?

AW: The commissioner wanted a piece for flute, around 10 minutes long. He didn't specify anything more specific than that. If they have an idea for a program that's interesting and gives me ideas, I'm happy to work with that. I wrote this piece for Cavalry Episcopal Church, Brigid's Fire. Jim Cassaro organized it, and it had to have something to do with this church. The building is magnificent, with so many beautiful things that can inspire you in different directions. I'm open to being pushed in one direction or another. But generally you know, you don't want it to be told "Write a piece about this." That can be very stifling compositionally. "Write a piece that sounds like this." "I really like that piece of yours, can you write another one like that?" That's 
death to a composer. But "I'm working on a series about this general topic, can you write a piece that fits it?" That's fine, and it can be fun.

It's rare that I would just get a musical idea and work with that, a melody or a chord progression or something like that. I usually need some kind of external influence to get the juices flowing. It would be hard to title pieces that don't have that in some way. Sometimes the titles come after the fact. They aren't really there for inspiration but they fit with the piece. You have to come up with the title and the program notes, it's nice to have something to write about besides "I really like this chord." Stravinsky said something about composers have to be extra influenced by everything around them. They have to have these highly attuned sensors to be very aware, because you never know where the influence is going to come from. So I try to be open and always keep a notebook and write ideas down and I never know where it's going to come from.

PM: When looking at your catalogue, it appears that most of your works are chamber pieces. Is that your preferred medium?

AW: It's wonderful to write for orchestra, but, again, it's not the most pragmatic. Unless you're focused on that as your primary goal, it's not very pragmatic to write for orchestra because the performance opportunities are so much more limited. It takes so much time. I just finished a fiveminute piece that was eight months of work. For me, chamber music is the most rewarding, especially because I enjoy that interaction with performers so much. I really, really love chamber music. I'm in a piano duo. I'm not a solo pianist. Occasionally I play solo concerts, but mostly I play with other people because I love the interaction and dynamic and energy that come from more than one person. 
PM: I did have one question about Movement IX. I think there is some discrepancy between different editions. Is there a version where that movement is centered around the pitch D? AW: Yes, with D as the pitch center, it is very difficult to get the microtonal and timbral variations, so the version centered around $\mathrm{E}$ is much less awkward and is the correct version. Also, the previous movement ends on E. Originally I thought the piece could be played in any order. You can do two movements or one, and you can, but the more I hear it, the more I feel it as a set. You could do Movement XI by itself. You could do a set of three short movements. If you're going to do all eleven, I think the order is got to be the order now.

PM: I know that Lindsey Goodman has programmed the piece where she's broken it up and interspersed the individual movements throughout the program. Could you comment on that? AW: I'm open. I think programming is fascinating, and I think composers need to be flexible about letting performers deciding how they want their shows to go. Depending on what it's paired with and combined with, I think that can work very well in that way. It could also work terribly. It's all in how well it's programmed and performed. When Lindsey did that it worked really nicely, but the piece did lose a little bit of its intensity and focus, because you forgot what else you'd heard of it. It felt like sorbet between the pieces rather than one substantial piece. But sorbet is good, nothing wrong with a little sorbet.

PM: Can you talk, as much as you are comfortable, about the sounds that you used throughout First Lines, and how they relate to the specific poems?

AW: In the first movement, I wanted something that was very direct, with a very clear impact. Rhythmically, I achieved that with the straight sixteenth notes. Things happen within that, and there are a few moments where it starts to feel like it could fall apart with the triplets, but mostly I wanted something that was direct. The clusters in the piano are like a pounding of a fist. It's an 
image of someone sitting there. This poem captured a particular mood, and, to me, it's not a sweet mood. "I sit in front of him and look him in the eye." That could be dreamy, sensual, loving. For me, it was, "we're going to talk about this." I wanted something with that kind of energy.

PM: Since you are a pianist, could you address the special performance techniques required by the pianist in this movement?

AW: In the recording, Eliza just didn't do it, which is strange because I don't think it's a difficult technique. It requires just holding a paper clip loosely in your hand so it will buzz, it will vibrate in the exact point in the string where it will hit the note to sound the octave and a fifth harmonic. On the low F, you have to find the spot where the harmonic occurs ahead of time and mark it with tape. You hold the paper clip lightly to the string, play the F, and it buzzes a little and it comes into focus. I think always in the piece there are things pulling away from the solidity. It should feel very solid except these moments of tension with have to do with the breathy sound in the flute, or noisy key clicks, or pitch bending, or triplets that pull away from that stability, so you are trying to be very clear but there are little things in the movement, details that make it feel like it could shatter. This solid object could fall apart. That's the glissandi, timbral fingerings, breathy sounds, and those things take it away from being really stable and solid.

PM: And that's something that's specific to this movement?

AW: Yes, I would say so. The line used in the second movement was chosen because it was an evocative sound for me of something that dissipates. Ice smoke, right? So you see the ring and it dissipates and thins out. That's the effect of a really solid attack with the piano and flute in unison and then this thing that just dissipates, the smoky thing that dissipates from it. So maybe this movement is a little more programmatic. Once the effect is done twice you don't want to 
repeat it the same way, so then the attack comes at the end of the sound. It's almost like seeing it in reverse, if the camera went backwards. It's reversing the same kind of figure. It's one of the shortest movements.

The third movement is the bees one. I wanted something sort of like nature. The free element of nature where things happen rhythmically that sound regular but they are also very unpredictable. If you hear crickets chirping it can feel regular but it turns into crazy polyrhythms if you try to notate it. I thought I would model that in a slightly simpler way, but not very simple for the pianist. This way, the pianist has this kind of quirky rhythm that's not quite right, but within each part you can hear regular, steady things. It's more a way of achieving a very unpredictable kind of rhythmic basis for the piece. Especially after the second movement where the flute and piano parts are so coordinated, and the sounds are so connected, I wanted a movement where the two instruments are two very independent creatures. The flute is more the air humming at night, and the buzzing sound is meant to be something other-worldly. The piano is more the clicking of the bees' wings. It's something that's found in nature. They play two very independent parts in terms of texture.

PM: Something I discovered in my coachings with you is that you write with such rhythmic precision, but it seems okay if it's mostly together. Is that fair to say?

AW: In a movement like this, it's never exactly right; it's four against five against seven. It looks like the flute comes in at the same time as the piano, but it's actually a little bit later.

Intentionally, with this movement, there's a certain amount of flexibility rhythmically because nothing is ever supposed to line quite up. As long as you know where you are, it's okay. The flutist follows the pianist. Just make sure you don't get too off. There are unison moments in this movement, but it always kind of comes out of the piano sound. 
Movement IV is unusual in that it is the only one that combines two different first lines from two different poems by the same author. I don't really recall how that happened. I think I got this idea for the piano bass line, this particular sound created by moving the fingers on the strings to get different harmonics to speak. It creates sort of a flexible sound, a changing color. That sound came first, and then I didn't really have a flute thing to go with it, and so then I thought I would combine the two poems. This one is maybe the most abstract use of the poem. It's not so direct. The piano, I guess, is the neon flickering, but it's just a sound, or an idea of a sound. It's an object but has other sounds associated with it. There's a neon sign, which is a visual thing, but there are sounds connected to it are peripheral. There's the noise of the thing itself. There's the sound of a cluster, but because of what you're doing inside the piano it's always changing unpredictably. The line "in the margin, you roam free" is a very flexible, fluid line that would exist on its own, from this other more focused image. To me, they work together as two separate ideas that could happen at the same time. In the piece the relationship between the flute and piano is different in different movements. That has to do with me thinking about the performers, and the relationship between them. In the third movement, they are quite independent, but there is some coordination. In the second movement, it's really supposed to sound like one instrument. In movement I, it's a conversation between two people. This is one where they really are quite independent rhythmically, registrally, and timbrally in terms of the character of what they're doing. But they share a rhythmic flexibility and they have a few of those attacks together. There are connection points and flexibility.

PM: Is this the movement where the pianist removes the music rack from the instrument? Do you recommend that method for this movement? 
AW: I always put the rack at an angle for the whole piece that way I don't have to move it and the strings are accessible. I move the rack back and to an angle so I can reach the bass strings and can still see the music and turn the pages. Everybody's gotten that. I did not work with Eliza and Andrea before the recording. It just arrived, fully edited and in my mail. That was an interesting experience for me because I am, I can be fairly obsessive like most composers. A few things, funny things, clearing pedal where it's not indicated to, but generally they really got the piece and it's a really wonderful performance of the piece. I think the notation is really clear because they were able to get it, 95\%, without working with me at all on it. That's a good sign.

Movement V has a little bit of reference to the pentatonic or Chinese-y sounding scale, so maybe that's obvious. But I didn't want it to be too direct. It happens mostly at the second and fourth bar. The relationship between the instruments here is very close. They're separated in register but there are places that they come together and the rhythmic coordination is very important. You know, to land on that fourth quintuplet together which is challenging with such a registral separation. But, there is a clear rhythmic emphasis in this one.

This one also seemed to me to work very well as something really short. It just gets started and then it's gone. When you start with something that's quite repetitive, this one returns to the same idea three times, and then it's cut off. Something new had to happen to make it dissipate. Otherwise you could develop it into something longer. It has a clear theme or motive that could be developed. So, rather than develop it, it's just cut off, and something new is inserted as an ending gesture.

Movement VI is the one that people can match to the poem. I've done experiments with students where I give them a poem and play the music to see if they can coordinate them. They have a difficult time, but this one they almost always get. It's the most directly narrative. At first, 
there is some kind of event that needs to be shushed and so that's kind of a big flourish and then the inhale and exhale breathing sound, which projects very well. That was a concern. I knew it could be done, but I was concerned about how loud it could be. There's never been a balance problem with that, it's always projected just fine. This one demonstrates another way of playing with rhythmic flexibility, but this time using tempo changes. So, there's a feeling of rubato, of flexibility, of something that is stable, but fluid. A moment of apnea, and then she breathes again in her sleep.

For movement VII, I knew I wanted something that would continue to rise, and I also wanted a very coordinated, blended sound between the two instruments, so it's really one instrument. There are times you feel more focused on one instrument than the other. But, the two are completely coordinated and synced timbrally. For that reason I didn't want to use the very lowest register of the flute because I felt like timbrally it's quite different from the piano since it loses its focus. I started a little ways up in register and ascended and ascended until they split apart at the very end and that's when the low register can come in and separate the two instruments.

This one is challenging rhythmically, but once you feel the right tempos, and can feel them together, it feels like one continuous gesture to me, always moving up. I think I'm quite interested in this idea of regular rhythm that's irregular, of ways of playing with rhythm where you can recognize what it's made out of but it's flexible.

PM: I had a question about the ending of the poem "The Athlete." You wanted the two instruments in tandem until the end. How did you decide on the particular ending you composed? 
AW: I think you probably noticed that often in these pieces that something different or special happens at the end. That was a way for me to get out of the pieces, to get out of each one so that they feel complete. I worked very hard on the endings of each one, so it didn't feel just feel chopped off. It also felt like it just couldn't keep going up. The piano can go up further than the flute. I didn't want to get into the super extreme high flute range. The piano could keep going, so what's the flute going to do? I'm either going to drop the flute out, which doesn't really make sense, or they're going to separate in terms of register at the end. In this case, they pulled apart. The flute couldn't go higher, so the piano took over at that high register. The flute asserted itself by bringing a new timbre, which is that low B. There isn't any low, low flute in the piece until there.

PM: What if the flute player doesn't have the low B on their flute?

AW: Actually, Andrea recorded it an octave higher. Did you notice that? I don't know why. He must have a B-foot joint on his instrument.

PM: Actually a lot of European flutists just play with a low C. I think that length of tube is better overall for the lower register and the extreme upper register. It's common.

AW: I could probably transpose the whole piece up, but it wouldn't fit so comfortably in the hands. The piano writing is always derived by what feels like piano music. If it were transposed, it might be tricky. I prefer it how it's written, but we always have to be pragmatic, right? Movement VIII was written later on, and I was wondering what else could I do in terms of the relationship between the flute and the piano. One thing I hadn't done is to write a solo piano piece where the flute only asserts itself once, in a kind of almost comical joking way to me. I see that line as kind of sarcastic, a nanny-nanny boo-boo kind of attitude. It was a way to explore a new relationship between the flute and piano that hadn't really been explored, especially after the 
last movement, where they're so coordinated. This one seemed to work to me as mostly as a solo. I wanted to explore the very incisive staccato attacks in the piano. It's more challenging in the flute to get that type of percussive attack.

PM: It can be, especially in the register you're writing. One of the things that's challenging about the fifth movement is matching the articulation in the flute's low register to the piano's. AW: This one to me was really a little solo piano piece, with only one gestural comment made in the flute. Movement IX is the one I ended up transposing to make it possible to get those trills really distinct, with quarter tones and timbral trills. I think it definitely works better centered on E. Again, it's a mood piece. It's an atmosphere in this one. There are very distinct instruments, and the relationship between the two is more pronounced. The piano is more accompaniment to the flute, which has the main idea. It feels like one that can go on a little longer than it does. I think that's the reason for the over-blowing moment, to signal a tension that it can't just continue. It feels like this atmosphere can just go on and on, so I had to do something a little bit more dramatic to say, “Ok." After that moment it can't just go back to what it was. So it starts to dissipate after that point. The piano is intentionally quite simple and the flute does basically one thing, so it's another example of very limited materials.

PM: Is there any need for suggestions on the piano instruction to "Slide finger towards damper so each note has a change in timbre. Do not move so far as to sound the next harmonic"? AW: Yeah, that on the recording, they completely misinterpret it. "Slide fingers towards damper, so each note has a change in timbre." It's very clear to me. It hasn't always been clear to pianists, so I should probably find a different way of notating it. It's a lateral movement, not along the strings, not chromatic, but staying on one string. Maybe it looks in the part like it should be a 
horizontal movement, because the sound moves up as the motion moves up towards you. But I probably should notate that a little more specifically because it has been misinterpreted. Movement $\mathrm{X}$ is one of my favorites. I'm not sure why. It felt like, at this point in the piece, that the flute and the piano needed to be coordinated again. I see it as a counterpart to movement II. Those movements feel like bookends. The piano is focused on articulating the attack of the flute. The rhythmic precision is very important in this one. They break apart in a few places. More and more they separate, so they're coordinated and then in measure 3, the piano does something else, then they're coordinated again, then in measure 5 the piano comes in early, and it's not doubling the flute pitches and the piano is offset, so there's coordination that starts pulling apart. Again, there's something special for the end, in this case the clicking, creaking, trembling sound. That one for me suggested a certain kind of rhythm, a quick-moving, trembling sound. That had its own rhythmic profile suggested by the poem.

What I like about movement XI is that it is not just that the water is calm, but that I was surprised by it. There has to be a sense of wonder or surprise in the piece. And so the piano is the water and so consistent and flowing, and the flute is a little bit more temperamental or moodier. It feels like two characters; the piano is very steady and flowing, and the flute is a little more improvisational, or rhapsodic.

I often have to tell flutists to really do a lot of dynamic contrasts in those over-blowings. Let it go really loud, really crazy. Super high notes and come back down. Sometimes they're a little bit cautious. Within the pianissimo they don't want to go too far. Because it feels so calm, you don't want to do something that just sounds aggressive. But a moment of aggression is okay. That's what makes it surprising. I understand that it's difficult to tune the harmonics and that's 
one of the challenging things is that there's so much pitch unison and on harmonics. That was a surprise for me. I didn't really think about that.

PM: You can't always control the piano you're going to have. It's one thing to get it in tune, but then another to have it match the piano.

AW: Getting the harmonics to tune to the piano is a little bit more challenging. That was something we discovered through the rehearsal process.

PM: I know your dad, Jan Williams, is a fairly influential figure in our field. What was it like to grow up with your dad? You said you come from a musical family. Is your mother a musician as well?

AW: My mom was a violist, she played with the local philharmonic for many years. She retired from there, and still plays. She had a string quartet growing up, so I used to go to orchestra rehearsals with my mom and sit there doing my puzzles during rehearsals. There were string quartets on the weekends rehearsing in my living room. That was the classical side of things. My father was a contemporary music percussionist. He organized festivals, brought composers to the house, concerts in the living room, parties, percussion ensemble concerts. I grew up with all his students going to all those concerts, and having dinner with Uncle Morty Feldman. I'm sure John Cage was at our house several times. As a child I didn't know this was unusual. I didn't know I was going to go into music. As a child, Morty was just this guy who talked a lot and smoked a lot and knew his concerts were really, really long. I had no idea the genius that was amongst us at the time. Reflecting back it's very special. I didn't know any other life. That was what I was born into.

Three of my four grandparents were pianists of some sort. There's been a deep love of music in my family forever. I have my grandmother's piano that was moved into my house the 
year I was born. It felt kind of inevitable. But I do believe that if I had gone to a music conservatory like SUNY Purchase or a conservatory like Oberlin, with so many fantastic musicians, I would probably not be a musician today. I was accepted at both, but there was something special about Bennington for me. That it was a liberal arts college, and I was able to have all those different experiences. Also, I was the only pianist, so I felt special there. And I wasn't writing my solo clarinet piece when there were others in the class who had already written symphonies. I felt very nurtured and supported there in particular and I might have been kind of ignored if I had gone to a conservatory with millions of talented pianists.

Even though I grew up in a musical family I felt like I could do anything, I could go in any direction I wanted. I never felt pressured to be a musician; in fact, maybe a little bit the opposite. But, being in this particular small liberal arts college environment, I got drawn right back into music. There it was where I decided I was going to be a musician. I'm sure it was feeling comfortable hearing all these sounds all the time and not thinking it's strange, and that's why I went into contemporary music particularly. Meeting composers, the personalities, the characters, the liveliness, and the energy goes into "That's what I want to do. Those are the people I want to be with." I did theater in college, but I liked the musicians better than I liked the theater people. That's part of how you get drawn into things.

It was a great upbringing to me. I had such experiences. There was such an openness. People came from all over the world, stayed in our house, brought their children, and their chickens, and their liquor, and their music. It was a lively environment and you never knew what was going to happen next, and I think that's a great thing.

PM: Who brought the chickens? 
AW: A guy, a recording engineer, his name was Max. He had a record label and an island off the coast of Maine. It was his own island where he raised chickens, and the chickens were too young to be left alone and so he had to bring them. And our basement didn't smell the same for months. But those were the kinds of experiences that were just great. Dinners with Morty Feldman were, you know, priceless really.

PM: Well now that you've developed the career you have, it must be wonderful to look back at those times.

AW: My sister speaks lovingly of these times as well. It was a lot of fun. Some of the concerts were interminable for ten year olds, but we sat through them. But it was great, really great. PM: Thank you so much for your time and willingness to share your insight and experiences. 


\section{APPENDIX III: Biographies of Interviewed Flutists}

Alberto Almarza

Flutist Alberto Almarza currently serves as Associate Professor of Flute at Carnegie Mellon University in Pittsburgh, PA. ${ }^{298}$ Originally from Chile, Almarza performed as Principal Flutist of the Philharmonic Orchestra of Santiago before moving to New York to study with Jeanne Baxtresser and Julius Baker. ${ }^{299}$ Pursuit of a Master's degree led him to Carnegie Mellon University, where he also co-directs of The Consummate Flutist, a week-long workshop that combines classes, lectures, and performances presented by master artists. ${ }^{300}$

As a pedagogue, Almarza is dedicated to coaching students on music old and new, and specializes in both Baroque and contemporary music. ${ }^{301}$ Almarza frequently performs on period instruments, and curates a collection of hundreds of flutes, dating from antiquity. ${ }^{302}$ In demand as a lecturer, Almarza offers presentations on a plethora of topics, including "Baroque Style for the Modern Flutist," "Alternative Fingerings for the Flute," "Extended Techniques," and "Native Flutes and the Origin of Extended Techniques." ${ }^{303}$ Almarza believes that developing the ability to perform on flutes from different cultures and historical periods, while also integrating the extended techniques required for contemporary music into one's repertoire, raises the level of a

298 "History," Alberto Almarza Flute, http://www.albertoalmarzaflute.com/biography/ [accessed 7 November 2014].

${ }_{300}^{299}$ Ibid.

300 "The Consummate Flutist," CMU Flute Forum, http://www.cmufluteforum.com/ [accessed 7 November 2014].

${ }_{301}^{301}$ Almarza, interview by author.

302 "Horizons: Ancient Flutes," WQED, http://www.wqed.org/tv/watch/?sid=488\&series=2 [accessed 7 November 2014].

303 "Lectures," Alberto Almarza Flute http://www.albertoalmarzaflute.com/lectures/ [accessed 7 November 2014]. 
musician's performance of every style and period of music. ${ }^{304}$ What might appear on the surface to look "so separate, so different, is actually very close to each other."305

Almarza has performed as a recitalist across the United States, Europe, Korea, and Latin America, and has collaborated with many Pittsburgh composers on recording projects. ${ }^{306}$ His performances can be heard on Chant and Dance: Chamber Works by Reza Vali, (Albany Records), Atacama: Four Chamber Works by Nancy Galbraith, (Elán Recordings), and A Sense of Time: Music of Efraín Amaya (Producciones Artísticas). ${ }^{307}$

Almarza performed First Lines with pianist Walter Morales in April 2007 in Pittsburgh, PA. ${ }^{308}$ The performance was part the U3 Festival, previously a bi-annual composition festival of three Pittsburgh universities: University of Pittsburgh, Duquesne University, and Carnegie Mellon Univesity. ${ }^{309}$ Williams and Almarza met twice in preparation of his performance, once with Morales and once without. ${ }^{310}$

\section{Andrea Ceccomori}

Dedicated to performing and commissioning contemporary music, Italian flutist Andrea Ceccomori has performed throughout Europe, Canada, the United States, South America, and Africa. ${ }^{311}$ Active as a recording artist, he can be heard on the many labels, including Amiata

\footnotetext{
${ }^{304}$ Almarza, interview by author.

305 "Honami," Alberto Almarza Flute.

306 "History," Alberto Almarza Flute.

307 "Recordings," Alberto Almarza Flute, http://www.albertoalmarzaflute.com/recordings/ [accessed 7 November 2014].

${ }^{308}$ Williams “Academic Curriculum Vitae."

${ }^{309}$ Almarza, interview by author.

${ }_{311}^{310}$ Amy Williams, E-mail message to the author, 7 November 2014.

311 "Biography," Andrea Ceccomori, http://www.ceccomori.it/contenuti2.php/lingua/eng/pagina/biografia [accessed 7 November 2014].
} 
Records, BMG/Ricordi, and Tweedle. ${ }^{312}$ His writings on disseminating contemporary music can be read in the journals Amadeus, Syrinx, and World New Music Magazine, among others. ${ }^{313} \mathrm{He}$ is the author of a method of study of contemporary techniques for the flute, titled Flute Today.

After graduation at the Conservatory of Perugia, Italy, Ceccomori continued his studies with many notable figures in the world of contemporary music, including flutist Severino Gazzelloni, an early advocate and developer of extended techniques of the flute. ${ }^{314}$ Ceccomori performs on every member of the flute family, from piccolo to contrabass flute. He has taught at a variety of institutions, with residencies at the University of Perugia and Università Roma in Italy, University of Georgia, University of Southern Mississippi, and Nazareth College in the United States, Porto Alegre in Brazil, and University of Belarus in Minsk. ${ }^{315}$ As an artistic administrator, he has organized numerous contemporary music festivals, primarily in Italy. Ceccomori's musical endeavors are varied, "from the improvisational to music in its relation with the image, to the studies surrounding music and spirituality. ${ }^{״ 316} \mathrm{He}$ is the co-founder of two ensembles: the Assisi Musiche Ensemble, dedicated to spiritual music and Arisanat Furieux Ensemble, which existed between 1987 and 1993 as a chamber ensemble performing contemporary music. ${ }^{317}$

Williams and Ceccomori met through their mutual colleague, Orlando Garcia, Professor of Music Composition in the School of Music Florida International University. ${ }^{318}$ Ceccomori approached Garcia to request recommendations for composers and compositions to program on a

\footnotetext{
312 Ibid.

313 "Biography," Andrea Ceccomori.

${ }^{314}$ Ibid.

${ }^{315}$ Ibid.

316 Ibid.

${ }^{317}$ Ibid.

${ }^{318}$ Ceccomori, interview by author.
} 
recording project featuring American Contemporary music for flute and piano, and Garcia suggested Williams. ${ }^{319}$ Ceccomori commissioned First Lines, and recorded it in 2008 with pianist Elitza Harbova. Ceccomori admires Williams' composition “because she uses contemporary musical language, but in a special new way: a way to express the real content of music and the poetic text. ${ }^{, 320}$ Ceccomori prefers to include First Lines on an eclectic music program, on combining contemporary with more traditional repertoire, to show the importance of both styles of music. ${ }^{321}$ Ceccomori and Harbova recorded First Lines on their album America, and performed it in the United States in September 2007 at Haverford College, Philadelphia. ${ }^{322}$

\section{Lindsey Goodman}

Flutist Lindsey Goodman is an advocate for contemporary music, specializing in electroacoustic compositions that combine live performance with pre-recorded track, live processing, or other sound modifications including computer-generated reverberation. ${ }^{323}$ An active commissioner of new works by emerging and established composers, Goodman has given almost seventy world premieres, including twenty-five solo and chamber compositions written especially for her. ${ }^{324}$ As a 14-year veteran as solo flutist of the Pittsburgh New Music Ensemble, Goodman has recorded two CDs and a DVD, participated in two international tours, and currently serves on its Board of Directors. Additional chamber music performances have taken her to Carnegie Hall (New York, NY), the Edinburgh Festival Fringe (Scotland), and The Fresh Ink Music Series (Charlotte, NC). Also an accomplished vocalist, Goodman co-founded

\footnotetext{
${ }^{319}$ Williams, interview by author, 24 January 2014.

${ }_{321}^{320}$ Ceccomori, interview by author.

${ }^{321}$ Ibid.

${ }^{322}$ Williams "Academic Curriculum Vitae."

323 "Press," Lindsey Goodman, http://lindseygoodman.com/press.html [accessed 8 November 2014].

${ }^{324}$ Ibid.
} 
Chrysalis, a "transformative" ${ }^{, 325}$ duo, where she both sings and plays the flute with tenor and pianist Robert Frankenberry. Goodman is also a founding member of ASS3MBLY, a flute, percussion, and piano trio which champions contemporary works. ${ }^{326}$

Also active as an orchestral musician, Goodman is principal flutist of the West Virginia and River Cities Symphony Orchestras, and plays piccolo with the Tuscarawas Philharmonic. Dedicated to education, Goodman serves on the faculty at Marietta College (Ohio), the CODA Mountain Academy of Music (Fayetteville, WV), and maintains an active private studio of students who are regularly invited to participate in honors festivals and ensembles. In demand as a clinician, Goodman frequently gives flute master classes and presentations on music careers and entrepreneurship, working with electronics, and the commissioning process to students at universities and colleges the United States, and recent appearances have taken her to Bowling Green State University (Ohio), University of Colorado at Boulder (Colorado), and Marshall University (West Virginia). ${ }^{327}$

Goodman studied extensively with New York Philharmonic's principal flutist Robert Langevin, earning a Bachelor's degree from Duquesne University (Pittsburgh, PA) and a professional studies diploma from the Manhattan School of Music's orchestral performance program. Goodman also studied with Walfrid Kujala, former principal piccolo of the Chicago Symphony Orchestra, receiving her Master's degree from Northwestern University, where she met Williams in 2001.

\footnotetext{
325 "Press," Lindsey Goodman.

326 Ibid.

${ }^{327}$ Ibid.
} 
When Goodman was working on her Master's degree at Northwestern, she performed frequently with the new music ensemble and first came to Williams' attention at that time. ${ }^{328}$ The two began working together, and Goodman was often a guest in Williams' composition classes, demonstrating various flute techniques to students. ${ }^{329}$ During that time, Williams shared a copy of her composition Cineshapes 1 for flute and bass drum, providing Goodman an introduction to her compositional catalogue. ${ }^{330}$ Williams was completing First Lines in the summer of 2006, and she and Goodman were both in Pittsburgh. Williams was by that time teaching at the University of Pittsburgh, and Goodman was in residence, performing on the Pittsburgh New Music Ensemble summer series. This provided an opportunity for Williams to consult Goodman on the flute writing in the piece. ${ }^{331}$ Goodman has coached the piece with Williams on several occasions, and has performed it five times since $2011 .^{332}$

\footnotetext{
${ }_{328}^{328}$ Lindsey Goodman, interview by author.

${ }^{329}$ Ibid.

${ }^{330}$ Ibid.

${ }^{331}$ Amy Williams, interview by author, 24 January 2014.

332 Amy Williams "Academic Curriculum Vitae."
} 


\section{ABOUT THE AUTHOR}

Flutist Pamela Murchison currently plays piccolo with the West Virginia, Akron, and Ohio Valley Symphony Orchestras and serves as the Executive Director of Pittsburgh New Music Ensemble. She is also active as a chamber musician, currently performing with Matt Murchison Mutiny. An advocate for the importance of audience engagement and enrichment, Pam's membership in Sound Gallery, Trillium Ensemble, Il Venti Simplice, and other chamber groups has led to performances and outreach throughout Pennsylvania, West Virginia, and Maryland. As a founding member of Mainspring, a chamber group devoted to a fusion of classical and world music, Ms. Murchison was featured on WQED-FM in Pittsburgh, and toured throughout the United States. She regularly participates in community and educational outreach, and presents an experiential workshop titled So Now What? Navigating the Road from Student to Professional, aimed at helping young musicians discover new career opportunities in the everchanging arts community. She holds degrees from Duquesne and Youngstown State Universities, and is completing her Doctor of Musical Arts degree at West Virginia University. 


\section{CURRICULUM VITAE}

\section{Education}

- West Virginia University

Morgantown, WV 2014

D.M.A. in Performance

- $\quad$ Youngstown State University

Youngstown, $\mathrm{OH}$

M. M. in Performancersumma cum laude

- $\quad$ Duquesne University

B.M. in Performance

Pittsburgh, PA

cum laude

2001

\section{Online Training and Workshops}

- $\quad$ ADA and Accommodation on the Web

Sloan Consortium

2013

- $\quad$ Effective Online Classrooms: Adult Learning

Sloan Consortium

2013

- Getting Organized in Your Blended Course

Sloan Consortium

2012

- $\quad$ Faculty Online Certification Program

Frostburg State University

\section{Teaching Experience}

- Frostburg State University

Applied Flute Lessons

- Responsibilities include designing individualized curricula for music majors and minors pursuing degrees in performance, education, and music business, and organizing and overseeing performance juries, studio, and degree recitals each semester.

Flute Ensemble

- Responsibilities include programming and coaching various chamber ensembles each semester, including flute quartet, flute and guitar duo, and woodwind quartet. On campus and outreach performances occur each semester.

Online and Hybrid Courses

Music, Lyrics, and Life

- A general education, interdisciplinary class that examines how music, poetry, sociology, and psychology interrelate. Taught without a textbook, all content for this course has been self-generated with media-rich content, and taught online during winter, spring, and summer sessions, and in hybrid format during the fall and spring semesters, for the past three years.

Women and Music

- Taught in hybrid format, "Women in Music" is a general education course fulfilling a humanities requirement for students in the music department, as well as students from other majors. This course is popular with students pursuing a major or minor in Gender Studies. 
Introduction to Music Theory

- I am developing a fully online music fundamentals course as part of Frostburg State University's Summer Online Freshman Initiative program. Introduction to Music Theory will serve as a pre-requisite for Written Theory I and Aural Skills I for incoming music students deficient in music fundamentals. The course will be offered Summer 2013.

\section{Teaching Experience, continued}

Other Courses

Aural Skills I, II, III, IV

- All four semesters of aural skills courses at Frostburg State University are fully aligned with the corresponding written theory courses. In addition to regular class meetings, individual consultations with students are scheduled, and Blackboard is integrated into the course as a means of organizing assignments, exam information, supplemental course content, and additional links pertinent to the class.

Introduction to Music Theory

- Fully integrated with the Written Theory and Aural Skills sequence, this course helps music majors deficient in fundamentals prepare for Written Theory I and Aural Skills I. Blackboard is utilized in this course as a means of organizing assignments, exam information, supplemental course content, and additional links pertinent to the class.

\section{Additional Teaching Experience}

- West Virginia University Morgantown, WV 2007-2010

- In the position of graduate assistant, responsibilities included teaching freshman level aural theory, teaching undergraduate and graduate flute majors and minors, conducting flute choir, coaching small flute ensembles, performing in graduate wind quintet, assisting in the organization of annual West Virginia University High School Flute Camp, coordinating the 2008 and 2009 Trevor Wye Flute Seminar, and securing grants to support guest artist appearances.

- Murchison Flute Studio

Pittsburgh, PA

1996-2009

- As proprietor, responsibilities included developing curriculum for individual students, recruiting, bookkeeping, and organizing two annual recitals.

- WVU High School Flute Camp Morgantown, WV 2007-2010

- Faculty responsibilities included leading daily technique class, coaching flute quartet, teaching theory class, and serving as Resident Assistant for boarding students.

\section{Additional Teaching Experience, continued}

- Youngstown State University Youngstown, OH 2005-2007

- Graduate assistant responsibilities included teaching undergraduate flute majors and minors, assisting in organizing and publicizing the annual Dana Flute Festival, organizing and coordinating volunteers for the Bands of America marching band 
competition, teaching woodwind methods, and securing grants to support guest artist appearances.

- Flute Academy

Pittsburgh, PA

2002-

- Faculty responsibilities included directing adult, high school, and junior high flute choirs, coaching small chamber ensembles, teaching theory and ear training, assisting in conducting and organizing concerts.

- Sherman School District

Sherman, TX

2001-2002

- Orchestra director and flute instructor responsibilities included teaching beginning string class, conducting junior high and high school orchestras, coaching students for All-State auditions, teaching individual flute lessons, and programming, organizing, and conducting two annual concerts.

Orchestral Performance Experience

- Ohio Valley Symphony

Gallipolis, $\mathrm{OH}$

2012-

Piccolo/flute III

- Akron Symphony Orchestra

Akron, $\mathrm{OH}$

2010-

Piccolo/flute III

- West Virginia Symphony Orchestra

Piccolo/flute III

Charleston, WV

2007-

- Dana Chamber Orchestra

Youngstown, $\mathrm{OH}$

2006

Concerto soloist performing Mozart's "Concerto in G, K. 313"

- Sherman Symphony

Sherman, TX

2001-2002

Principal piccolo

\section{Chamber Music Performances and Ensembles}

- Celebrating Women Composers

- This program of music for flute, clarinet, and piano will be performed at the MidAtlantic Flute Fair in Reston, VA.

- $\quad 21$ st Century Works for Flute, Cello, \& Percussion

2012

- Performed in three cities, and accompanied by a panel discussion with the performers, this program included music written by living composers, including David Lang, Andy Akiho, Amy Williams, and David Stock.

- Matt Murchison Mutiny Pittsburgh, PA

$2011-$

- This chamber group blurs the line between classical and popular music and performs original compositions and arrangements for the unique instrumentation of the group, which includes flute, piano, euphonium/tuba, and percussion.

- Trillium Ensemble

Pittsburgh, PA

2010-2012

- A chamber ensemble consisting of flute, clarinet, and piano, Trillium Ensemble presented a series of three yearly programs of newly composed music, including premiers of works commissioned by the ensemble. 
Chamber Music Performances and Ensembles, continued

- WV University Graduate Wind Quintet Morgantown, WV 2007-2010

- Weekly rehearsals and coachings of both standard and new repertoire for wind quintet culminated in biannual performances and educational outreach performances.

- WV University Flute Choir Morgantown, WV 2007-2010

- Weekly performances and coachings of music for small and large flute ensemble culminated in biannual concerts, and included outreach performances in the Morgantown community, as well as at the National Flute Association Convention in New York in 2009, and the Central Ohio Flute Association Flute Day in 2010.

- Mainspring World Music Group Pittsburgh, PA 2004-2007

- Responsibilities included securing grants from the Pittsburgh Council for the Arts and the Pittsburgh Concert Society and assisting in the organization of performances in Pennsylvania, Texas, Connecticut, Colorado and Arkansas.

\begin{tabular}{lll} 
Guest Artist Recital Appearances & & \\
- Ohio University & Athens, OH & 2014 \\
- Pickerington Piccolo Day & Pickerington, OH & 2014 \\
- West Virginia State University & Institute, WV & 2012 \\
- Kanawha Forum Recital Series & Charleston WV & 2012,2010 \\
- Slippery Rock University & Slippery Rock, PA & 2011 \\
- Bach, Beethoven and Brunch Series & Pittsburgh, PA & 2007 \\
- Music at St. John's Concert Series & Altoona, PA & 2007 \\
- International Tuba \& Euphonium Conference & Denver, CO & 2006 \\
- University of North Texas & Denton, TX C & 2006 \\
- University of Arkansas & Fayetteville, AR & 2006 \\
- Arkansas State University & Jonesboro, AR 2006 & \\
- University of Central Arkansas & Little Rock, AR & 2006 \\
- University of Connecticut & Storrs, CT & 2005 \\
- Connecticut College & New London, CT & 2005 \\
- Fairmont State University & Fairmont, WV & 2005 \\
\hline
\end{tabular}

Masterclass and Lecture Appearances

- Mid-Atlantic Flute Fair Reston, VA

- "So Now What? Navigating the Road from Student to Professional"

- West Virginia State University Institute, WV

- "Risks and Rewards: Approaching $21^{\text {st }}$ Century Chamber Music"

- West Virginia Univeristy Flute Institute Morgantown, WV 2012

- Panel participant for orchestral audition masterclass

- Youngstown State University $\quad$ Youngstown, OH 2008

- Dana Flute Festival

- University of Arkansas

Fayetteville, AR

2006 - "Developing and Maintaining a Successful Private Studio"

- Arkansas State University Jonesboro, AR 2006

- Developing and Maintaining a Successful Private Studio" 
- University of Connecticut Storrs, CT

- Developing and Maintaining a Successful Private Studio"

\section{Masterclasses and Summer Festivals}

- West Virginia University Flute Institute

- Jeanne Baxtresser Masterclass

- Trevor Wye Seminar

- Blossom Music Festival

Morgantown, WV

New York, NY

Morgantown, WV

Kent, $\mathrm{OH}$

Selected as alternate flute for the 2007 summer festival

- American Wind Symphony

- Eastern Music Festival

Greensboro, NC
2010

2009

2008,2009

2007

2007

1999

\section{Service}

- Akron Symphony Orchestra Committee

- West Virginia Symphony Orchestra and Woodwind Audition Committees

- National Flute Association

- 2008 - Served as a judge on a committee to chose winners in the Newly Published Music Competition

- 2007 - Served as Equipment Manager for 2007 National Convention

- West Virginia University Flute Club

- President 2008-2010

- Pittsburgh Flute Club

- Member since 1993

- Treasurer 2002-2009

- As a board member, I helped to organize bi-annual adjudication festival, Young Artist Competition, and frequent guest artist masterclasses and recitals

\section{Professional Memberships}

- National Flute Association

- Pittsburgh Flute Club

- College Music Society

\section{Primary Teachers}

Dr. Francesca Arnone

Assistant Professor of Flute, West Virginia University

Dr. Kathryn Umble

2005-2007

Assistant Professor of Flute, Youngstown State University

Rhian Kenny

1997-2001

Principal Piccolo, Pittsburgh Symphony Orchestra 